\title{
PARÂMETROS DE CONTROLE DO PROCESSO DE COQUEIFICAÇÃO DAS BATERIAS DE FORNOS DE COQUE DA COSIPA
}

Dissertação apresentada à Escola Politécnica da Universidade de São Paulo, para a obtenção do título de Mestre em Engenharia Elétrica. 


\title{
PARÂMETROS DE CONTROLE DO PROCESSO DE COQUEIFICAÇÃO DAS BATERIAS DE FORNOS DE COQUE DA COSIPA
}

\author{
Dissertação apresentada à Escola \\ Politécnica da Universidade de São Paulo, \\ para a obtenção do título de Mestre em \\ Engenharia Elétrica.
}

Área de Concentração: Microeletrônica

Orientador: Professor-Doutor

Francisco Javier Ramirez-Fernandez 
Este exemplar foi revisado e alterado em relação à versão original, sob responsabilidade única do autor e com a anuência de seu orientador.

São Paulo, 25 de março de 2008.

Assinatura do autor

Assinatura do orientador

FICHA CATALOGRÁFICA

Costa, Luiz Cláudio

Parâmetros de controle do processo de coqueificação das baterias de fornos de coque da Cosipa / L.C. Costa. -- ed.rev. -São Paulo, 2008.

$89 \mathrm{p}$.

Dissertação (Mestrado) - Escola Politécnica da Universidade de São Paulo. Departamento de Engenharia de Sistemas Eletrônicos.

1.Automação 2.Controle de processos 3.Projeto de experimentos 4.Processo de coqueificação 5.Coqueria I.Universidade de São Paulo. Escola Politécnica. Departamento de Engenharia de Sistemas Eletrônicos II.t. 


\section{AGRADECIMENTOS}

Em primeiro lugar quero agradecer a Deus que me deu saúde e entusiasmo para a realização desse mestrado. Quero agradecer também à minha esposa Elizete, por ter sempre me apoiado nessa empreitada e ter aceitado ficar de lado tantas vezes em que eu ficava por conta exclusiva dos estudos, por ter suportado meus maus humores com o stress nos dias mais críticos. Agradeço também aos meus filhos por me ajudarem a manter o ânimo nesse período e por compreenderem as minhas ausências como pai.

Agradeço ao Professor-Doutor Francisco Javier Ramirez-Fernandez, meu orientador por ter acreditado em mim e ter me apoiado no quesito mais importante: a minha autoconfiança, pois, a sabedoria não se passa, mas se faz germinar. Agradeço também aos meus professores da Escola Politécnica, que contribuíram significativamente nesse trabalho, em especial, ao professor doutor Cláudio Garcia. Faço um agradecimento especial aos bibliotecários das várias bibliotecas da Escola Politécnica da USP, que sempre me atenderam prontamente em todos os meus pedidos. Não posso esquecer de agradecer também ao pessoal da secretaria de pós-graduação e às secretárias do departamento de microeletrônica, que sempre me atenderam com eficiência.

Agradeço à Companhia Siderúrgica Paulista, a Cosipa, por ter permitido e custeado meu transporte para a realização desse mestrado. Faço um agradecimento especial ao superintendente da Redução, Paulo Roberto Torres Matta, por ter me dado inspiração em fazer esse mestrado, ao lançar o desafio para todos do departamento que devemos sempre ser melhor a cada dia. Agradeço também ao meu chefe imediato, Eduardo Maurell Lobo Pereira, que me liberou sempre que precisei para meus estudos na USP. Agradeço também à Vanessa Pereira Straioto, bibliotecária do Centro de Informações Técnicas da Cosipa e a todas as estagiárias que trabalharam com ela nesses últimos 2 anos, por toda ajuda na busca de dados, livros e artigos que precisei. Agradeço à Superintendência de Informações Técnicas que, com seu acervo técnico, a facilidade e rapidez em passar informações, foram muito importantes para o desenvolvimento de meu mestrado. Faço um agradecimento particular ao Paulo Roberto Santos Dantas, laboratorista, que fez praticamente todos os experimentos com o forno piloto, toda a preparação e o controle dos dados. O sucesso da execução dos experimentos no forno piloto foi 
devido à sua dedicação nesse trabalho. Agradeço também a todos do laboratório da coqueria que viabilizaram esses testes. Agradeço ao técnico em instrumentação Edílson e ao analista Luiz Flávio pelos trabalhos de melhoria e manutenção no forno piloto. Agradeço aos inspetores Francisco Januário da Luz e Davi Cordeiro de Almeida, à equipe da ORMEC e da UEC pela execução do experimento no forno industrial. Agradeço também ao Eliezer que ajudou a viabilizar todas as medições com termopares no forno industrial. Agradeço à equipe de automação da Cosipa, ao Nilson e ao Thiago, principalmente, pelo auxilio na aquisição dos dados tanto do forno piloto quanto do forno industrial. Agradeço ao Ulisses Tetti, que me auxiliou bastante nas minhas dúvidas sobre estatística e no manuseio do software Statistica. Agradeço ao Amauri, ao Antônio Luiz e ao Tadeu, cosipanos veteranos da pósgraduação na USP, que me auxiliaram nas dicas e, principalmente, no meu ingresso na USP.

Enfim, agradeço aos meus colegas de mestrado, Mauro, Gilberto, e outros que estudamos juntos e passamos muitas horas fazendo trabalhos para as matérias do mestrado. Agradeço também a todos aqueles que, de alguma forma me ajudaram nessa empreitada e que, por esquecimento ou por não lembrar o nome, não citei aqui.

Muito Obrigado a todos. 
"Mesmo que eu tivesse o dom da profecia e conhecesse todos os mistérios e toda a ciência, se não tiver amor, não sou nada." (1Cor 13, 2). 


\section{RESUMO}

O controle de processo de uma planta de fabricação de coque depende de muitas variáveis particulares de cada planta. A busca de modelos de controle próprios torna-se necessário. O presente trabalho apresenta um projeto de experimentos, em forno piloto, para investigar a influência dos principais parâmetros de controle de fabricação do coque quanto à produção e consumo de calor e utilizá-los futuramente num modelo de automação do controle do processo dessa planta. O resultado do experimento apresentou significância estatística para os fatores temperatura e umidade da mistura enfornada e para as interações entre umidade e temperatura e entre umidade e granulometria com relação ao consumo de calor e também o fator temperatura com relação ao tempo líquido de coqueificação. Além do projeto de experimentos em forno piloto foi feito também um experimento em um forno industrial cuja metodologia mostrou-se adequada para um projeto em escala industrial. Com os dados dos experimentos obtiveram-se também equações matemáticas de previsão do consumo de calor e do tempo líquido de coqueificação.

Palavras-chave: Automação. Controle de processos. Projeto de experimentos. Processo de coqueificação. Coqueria. 


\begin{abstract}
The process control of a coke plant depends on a lot of particular parameters. This work describes an experimental design in a pilot oven aiming at getting the influence of the main control factors of a coke oven battery, relating these parameters with production and heat consumption for future process control automation. The result of the experiment showed statistic significance for the factors temperature and coal blend moisture and for the interactions between temperature and coal blend moisture and between moisture and coal size on the heat consumption and also for the factor temperature on the net coking time. Theses relations can be used to develop coking control at an industrial plant. In addition to the design of experiments in a pilot oven, it was also made an experiment in an industrial battery oven whose methodology showed to be appropriated to an industrial design of experiment. With the experimental data it was possible to write mathematical equations for estimation of heating and net coking time.
\end{abstract}

Keywords: Automation. Process control. Experimental design. Coking process. Coke plant. 


\section{LISTA DE ILUSTRAÇÕES}

Figura 1 - Esquema dos dois principais tipos de reações de carbonização (LOISON; FOCH; BOYER, 1989).

Figura 2 - Perfis de temperatura da massa de carvão enfornada em diversos momentos da coqueificação (MERRICK, 1983). 26

Figura 3 - Processo de coqueificação mostrado esquematicamente num corte do forno carregado e o perfil de temperatura nesse momento da coqueificação. 27

Figura 4 - Bateria de fornos de coque de projeto Krupp Koopers. 31

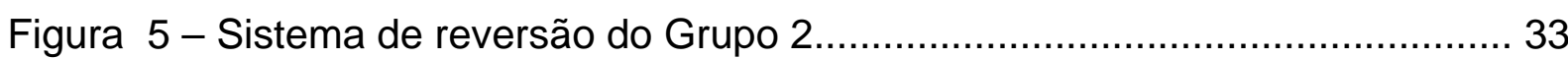

Figura 6 - Sistemas de controle das baterias de fornos de coque da Cosipa........ 37

Figura 7 - Configuração básica do sistema ACC ............................................. 40

Figura 8 - Modelo do Controle de Coqueificação da NSC........................................ 41

Figura 9 - Sistema de controle de coqueificação da Sidmar.................................. 43

Figura 10 - Sistema CETCO de controle do Aquecimento da Corus....................... 44

Figura 11 - Sistema de controle do processo de coqueificação das baterias da Siderúrgica Bhilai, da Índia............................................................... 45

Figura 12 - Forno piloto da Cosipa utilizado nos testes........................................... 54

Figura 13 - Silo de carregamento de carvão do forno piloto................................... 55

Figura 14 - Diagrama de causa e efeito do processo de coqueificação para o consumo de calor e o tempo líquido de coqueificação das baterias de fornos. 57

Figura 15 - Janela de opções de fatorial com 2 níveis do Software Statistica. 60

Figura 16 - Janela de opções do software Statistica para análise dos resultados do fatorial em dois níveis 61

Figura 17 -Temperaturas medidas da carga de carvão e do gás gerado do forno 72 da Bateria 5 da Cosipa... 68

Figura 18 - Consumo de energia e temperaturas medidas para determinação do tempo líquido de coqueificação.do $6^{\circ}$ experimento.. 72

Figura 19 -Média Marginal com seus limites de confiança gerados pelo software Statistica. 74

Figura 20 -Efeitos dos fatores sobre a variável Consumo de Calor. 75 
Figura 21 - Probabilidade Normal dos Resíduos para o Consumo de Calor.

Figura 22 - Significância estatística dos fatores sobre o tempo líquido de

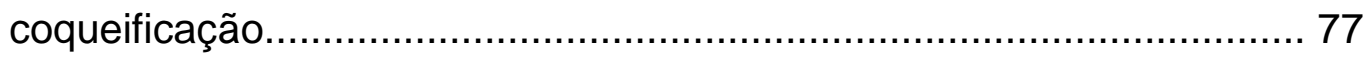

Figura 23 - Probabilidade Normal dos Resíduos para o tempo líquido. 78

Figura 24 -Relação entre a granulometria da mistura de carvões e sua densidade depois de enfornada...... 80 


\section{LISTA DE TABELAS}

Tabela 2.1 - Dados operacionais das baterias de fornos da Cosipa.......................31

Tabela 3.1 - Fatores e níveis do Projeto de Experimentos............................... 59

Tabela 3.2 - Delineamento do Projeto de Experimentos.................................. 59

Tabela 4.1 - Composição da mistura de carvões do experimento......................... 64

Tabela 4.2 - Seleção e identificação do material a ser utilizado nos experimentos. 65

Tabela 4.3 - Seqüência de enfornamento com os dados de densidade................. 66

Tabela 5.1 - Dados dos fatores e resultados dos experimentos......................... 71

Tabela 5.2 - Resultados da ANOVA para o efeito Consumo de Calor................... 73

Tabela 5.3 - Dados reais dos experimentos para o cálculo da regressão múltipla.. 76

Tabela 5.4 - ANOVA para a variável resposta Tempo Líquido............................. 77 


\section{LISTA DE ABREVIATURAS E SIGLAS}

$\begin{array}{ll}\text { ACC } & \text { Automatic Coking Control } \\ \text { ANOVA } & \text { Análise de Variância } \\ \text { AV } & \text { Carvão Alto Volátil } \\ \text { CEC } & \text { Ceramic Enterprise Cokery } \\ \text { CET } & \text { Coke End Temperature } \\ \text { CETCO } & \text { Coke End Temperature Control Coking System } \\ \text { CLP } & \text { Controlador Lógico Programável } \\ \text { CP } & \text { Coque Verde de Petróleo } \\ \text { CTC } & \text { Carro de Transferência de Coque } \\ \text { GAF } & \text { Gás de Alto Forno } \\ \text { GCO } & \text { Gás de Coqueria } \\ \text { GM } & \text { Gás Misto ( GCO + GAF) } \\ \text { LC } & \text { Lado do Coque - lado da bateria de fornos de coque onde sai o coque } \\ & \text { no desenfornamento } \\ \text { LD } & \text { Lado da Desenfornadora - lado da bateria de fornos de coque onde fica } \\ & \text { a máquina desenfornadora } \\ \text { MV1 } & \text { Carvão Médio Volátil } \\ \text { MV2 } & \text { Carvão Médio Volátil } \\ \text { NSC } & \text { Nippon Steel Corporation } \\ \text { PCI } & \text { Poder Calorífico Inferior }\end{array}$




\title{
LISTA DE SÍMBOLOS
}

\author{
$\alpha . \quad$ coeficientes do tempo líquido \\ $\beta \quad$ coeficientes do tempo líquido \\ $\Delta T \quad$ valor estimado do elemento inerente dentro do bloco \\ $T_{H i} \quad$ tempo líquido de coqueificação \\ $\theta \quad$ valor médio das temperaturas \\ $\Delta \theta$ máximo diferença de temperatura máxima para ação de controle \\ $T_{\text {MAX }} \quad$ Tempo entre o enfornamento o momento onde a temperatura do gás \\ gerado atinge seu valor máximo. \\ $\operatorname{Vobj}_{G C O} \quad$ vazão objetivada de GCO \\ V $\quad$ vazão de GAF medida \\ $\mathrm{t}$ tempo de queima por reversão de cada bateria (s) \\ E energia específica por tonelada de carvão seco enfornado (GJ/t) \\ $\mathrm{n} \quad$ número total de desenfornamentos por dia \\ $G_{D} \quad$ carga por forno média ( $t$ ) \\ $\mathrm{H}_{\mathrm{u}} \quad$ poder calorífico do gás de aquecimento $\left(\mathrm{GJ} / \mathrm{Nm}^{3}\right)$ \\ Q fluxo de gás por bateria $\left(\mathrm{Nm}^{3} / \mathrm{h}\right)$ \\ $\mathrm{Cl} \quad$ Índice de Coqueificação \\ $t_{c} \quad$ tempo total de coqueificação ou tempo bruto, em minutos \\ PR tempo de pausa na reversão \\ K constante proporcional (ganho) \\ Treg temperatura do regenerador \\ $\mathrm{Ti} \quad$ constante integral \\ $\Delta T_{c t} \quad$ diferença estimada da temperatura final do coque devido à variação do \\ tempo bruto de coqueificação $\left({ }^{\circ} \mathrm{C}\right)$ \\ c e d funções lineares do tempo de coqueificação e o formato da escala de \\ desenfornamento \\ T média da temperatura final do coque das séries anteriores \\ $\Delta T_{H} \quad$ diferença estimada da temperatura final do coque \\ a \\ função linear do fluxo de calor anterior e posterior a dois ciclos \\ completos de coqueificação
}


b função do tempo de coqueificação das séries

T.cet,pr a temperatura final do coque prevista

Tcet temperatura final de coque medida

$\mathrm{Ht} \quad$ calor total necessário

hd(Fornoi) calor necessário para o forno i

hl.wg perda de calor pela fumaça por forno

Shl perda de Calor pela superfície por forno

$\mathrm{N} \quad$ número total de fornos da bateria.

Tn horário de Desenfornamento do enésimo enfornamento de um forno

Tn-1 horário de Enfornamento do (n-1) enfornamento de um forno

CPD tempo médio de coqueificação

$\mathrm{KCl}$ e Kt constantes

$\mathrm{Cl} \quad$ índice de coqueificação

Cla índice atual de coqueificação

Cld índice desejado de coqueificação

$\mathrm{Ta}$ temperatura atual da massa de coque

Td temperatura desejada da massa de coque.

Fn, fluxo térmico

Fn1 fluxo térmico

Fn2 fluxos térmico previsto pelo modelo

Q consumo de calor em kWh

$\mathrm{T}$ temperatura das paredes do forno piloto em ${ }^{\circ} \mathrm{C}$

U $\quad$ umidade da mistura de carvão enfornada em \%

G granulometria $<3,36 \mathrm{~mm}$ da mistura de carvão enfornada em \%

$t_{\mathrm{L}} \quad$ tempo líquido de coqueificação 


\section{SUMÁRIO}

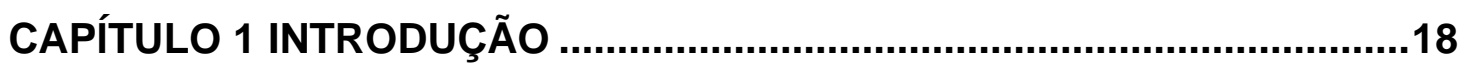

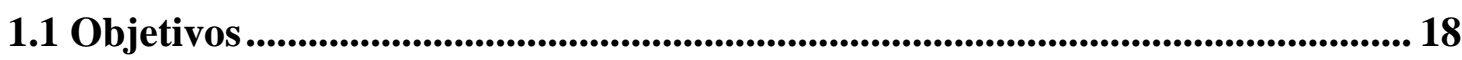

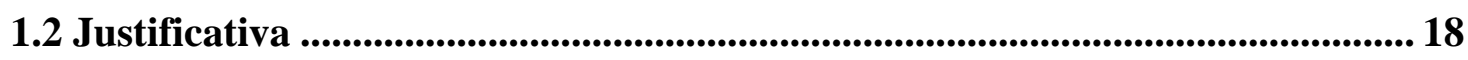

1.3 Metodologia ........................................................................................................................ 19

1.4 Caracterização do Problema ................................................................................... 20

1.5 Organização da Dissertação........................................................................................ 21

CAPÍTULO 2 DESCRIÇÃO DO PROCESSO DE FABRICAÇÃO DO

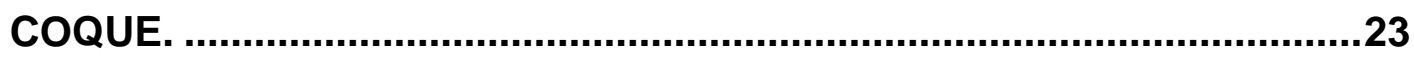

2.1 O processo de Coqueificação .................................................................................. 23

2.1.1 O processo físico-químico da Coqueificação ……………………………….... 23

2.1.2 A dinâmica da transferência de calor no processo de coqueificação................. 25

2.2 As Baterias de Fornos de Coque da COSIPA ....................................................... 29

2.2.1 A Estrutura das Baterias ................................................................................. 29

2.2.2 O sistema de aquecimento dos fornos ............................................................. 32

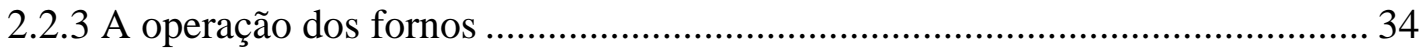

2.3 O sistema de controle das Baterias de Fornos de Coque ....................................... 35

2.3.1 O sistema de controle atual das Baterias da Cosipa ............................................ 35

2.3.2 O sistema de controle existente em outras plantas ............................................ 38

2.3.3 O que é mais viável implantar em automação de controle do processo de aquecimento na planta da Cosipa.............................................................................. 47

CAPÍTULO 3 O PROJETO DE EXPERIMENTOS ......................................51

3.1 Os conceitos básicos do Projeto de Experimentos .................................................. 51

3.2 Preparação dos Equipamentos - o forno piloto ..................................................... 53

3.3 Escolha dos Fatores e dos Níveis do Projeto de Experimentos............................. 55 
4.1 Preparação das misturas para o enfornamento 63

4.2 Enfornamento e desenfornamento das misturas de carvão 66

4.3 Execução do experimento no forno industrial 67

4.4 Análise do desempenho da execução dos experimentos 69

DISCUSSÃO DOS RESULTADOS .70

CAPÍTULO 5 .70

5.1 Apresentação dos resultados dos enfornamentos 70

5.2 As análises feitas através do software Statistica 72

5.2.1 Análise dos dados do Consumo de Calor 72

5.2.2 Análise dos dados do Tempo Líquido de Coqueificação 76

5.3 Análise dos dados do experimento em forno industrial 79

5.4 Discussão dos resultados do projeto de experimentos. 79

5.5 Discussão dos resultados do experimento no forno industrial. 81

5.5 Análise final dos resultados. 82

CAPÍTULO 6 CONCLUSÕES E PROPOSTAS DE PESQUISA 84

6.1 Conclusões do projeto de experimentos no forno piloto 84

6.2 Conclusões do experimento em um forno industrial 84 


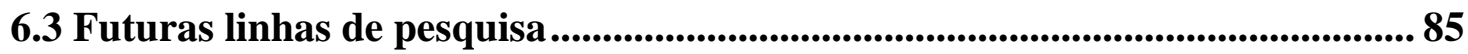

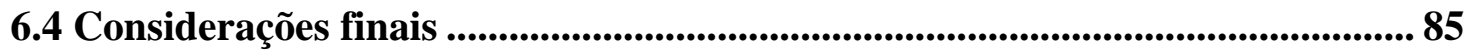

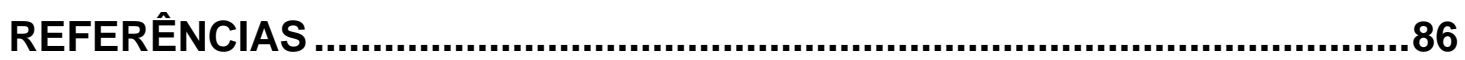




\section{Capítulo 1 INTRODUÇÃo}

\subsection{Objetivos}

O escopo deste trabalho é identificar as principais variáveis do processo de coqueificação das baterias de fornos de coque da Companhia Siderúrgica Paulista Cosipa que possam ser manipuladas ou, quando apenas monitoradas, possam permitir ações de controle sobre o processo para modificar o seu efeito, com o objetivo de controlar o consumo de calor e o tempo de coqueificação.

O método de identificação empregado é o Projeto de Experimentos com fatorial completo de três fatores (temperatura da parede de aquecimento, umidade e a granulometria da mistura de carvões) em dois níveis com repetição. Esse método estatístico vai apontar as influências dos fatores escolhidos e das interações entre eles sobre o consumo de calor e o tempo líquido de coqueificação. Além de apontar a significância estatística, este trabalho também calcula os parâmetros da equação linear de estimativa do processo para cada resposta do experimento.

De posse dessas informações será possível desenvolver um programa de controle de fluxo de calor para atender ao processo de coqueificação das baterias de fornos de coque da Cosipa.

\subsection{Justificativa}

Uma indústria siderúrgica consome grande quantidade de energia para a produção do aço (MINISTÉRIO DAS MINAS E ENERGIA, 2005). Todos os esforços na redução dessa energia, trazem redução de custo e de impacto ambiental. A coqueria é um dos grandes responsáveis pelo consumo de energia na siderurgia e também um gerador de combustível. A busca de maior produtividade da planta, da melhoria da qualidade de seus produtos e da redução do consumo de combustível desencadeia reduções de energia nas plantas clientes da coqueria. Por causa dessa 
característica da coqueria, o controle do processo de fabricação do coque é de importância estratégica para a indústria siderúrgica, tanto na redução de custos, quanto no controle ambiental (LARSSON; WANG; DAHL, 2006).

O controle do aquecimento dos fornos de coque é o principal controle do processo de fabricação do coque. A qualidade do coque e a qualidade do gás de coqueria dependem de uma boa distribuição do calor ao longo das paredes dos fornos. Para que haja uma distribuição otimizada do calor, deve-se ter domínio do controle de aquecimento do processo de coqueificação (STONE et al., 1997). Além disso, um controle otimizado do processo de aquecimento dos fornos garante maior vida útil para a bateria de fornos como um todo (MITRA et al., 2004). Desta forma, o conhecimento das variáveis que influenciam nesse processo é primordial para a sua otimização.

\subsection{Metodologia}

A experimentação é uma das principais ferramentas para conhecer um processo industrial. As dificuldades de identificar e controlar todas as variáveis que influenciam no processo tornam a experimentação uma tarefa bastante complexa, principalmente, na análise dos resultados (LOHMANN; BOCK; SHLÖDER, 1992). Muitas vezes, a quantidade de experimentos que se quer fazer torna o estudo econômica ou tecnicamente inviável. Para minimizar erros e reduzir custos e tempo de experimentação, é necessário um planejamento adequado e conhecimento prévio do processo a ser estudado (MONTGOMERY, 2005). Uma forma de experimentação é analisar um fator de cada vez, mantendo, dentro do possível, os demais fatores constantes. Essa forma é custosa e não consegue detectar, por exemplo, a interação entre os fatores, que em alguns casos chegam a ser mais significativos para o processo do que os fatores da interação individualmente. Já o projeto de experimentos fatorial completo, desenvolvido nesse trabalho, é uma metodologia estatística que analisa todos os fatores e todas as suas interações, obtendo a significância estatística da influência desses fatores e suas interações sobre as respostas do estudo, tanto qualitativamente quanto quantitativamente. O projeto de experimentos é uma metodologia de experimentação que envolve todas as etapas 
do processo do projeto, desde o objetivo do estudo, a escolha das variáveis, tanto os fatores que influenciam o processo em estudo como as suas respostas, até a análise dos erros inerentes a toda experimentação. Essa metodologia é uma abordagem científica para planejar, de forma mais eficiente, um experimento com resultados mais robustos (MONTGOMERY, 2005). O capítulo 3 apresenta maiores detalhes do projeto de experimentos.

Um teste industrial exige uma grande quantidade de material, alteração da seqüência operacional e uma dificuldade de monitorar diretamente fatores do processo de coqueificação como a temperatura das paredes de aquecimento que são medidas na base da câmara de combustão. Um teste em forno piloto também tem suas limitações, mas a flexibilidade e a disponibilidade de realização de testes, o torna mais viável para certos experimentos (LOISON; FOCH; BOYER, 1989). Ele tem a largura de um forno industrial e as outras dimensões bem menores. A geometria desse forno em comparação com o industrial, leva em conta que a transferência de calor ocorre principalmente da parede lateral para o centro do forno, diminuindo a influência da grande diferença da altura e do comprimento (LOISON; FOCH; BOYER, 1989; MAHONEY et al., 2005).

Os experimentos desse trabalho serão realizados no forno piloto da Cosipa, que foi incrementado com algumas melhorias descritas no capítulo 3.

\subsection{Caracterização do Problema}

O processo da coqueria é complexo pela sua particularidade no manuseio de carvão e gases combustíveis. Os riscos de danos ambientais e de explosão determinam a necessidade de controles robustos e de pessoal altamente qualificado. As baterias de fornos de coque são equipamentos de vida útil longa, entre 35 e 50 anos e de investimento de alto valor. Essas características explicam o grande número de baterias com idade acima de 30 anos em operação em todo mundo (CHISTYAKOV; CHISTIAKOVA; BOIKOVA, 1998). Quando se quer implantar automação no controle do processo da coqueria, a complexidade de avaliar os parâmetros é diretamente ligada ao tipo construtivo das baterias, à variação das misturas de carvão utilizadas e até a cultura dos operadores da planta. Essas 
condições da coqueria levam à necessidade de se analisar particularmente cada planta antes de implantar algum modelo de automação.

A Cosipa possui duas baterias de fornos de coque com 31 fornos cada e altura de $4 \mathrm{~m}$ construídas em 1965, projeto CEC (França), outra de mesmo projeto construída em 1972, com 35 fornos que formam o Grupo 1 e duas maiores de 53 fornos cada com $6 \mathrm{~m}$ de altura e projeto Krupp Koppers (Alemanha) construídas em 1976 e 1983 respectivamente, que formam o Grupo 2. O sistema de controle dessas baterias, descrito no capítulo 2, mostra a fragilidade do controle manual do consumo de calor e do tempo de coqueificação. Para automatizar esse processo é necessário primeiro conhecer bem as variáveis mais influentes e determinar os pontos de monitoração e controle. Existem muitos modelos de automação no mercado para controle das plantas de fabricação de coque. Pode-se comprar um modelo ou desenvolver um próprio, mas ambos precisam de um bom domínio das variáveis do processo específico da planta. Assim, a necessidade de se conhecer os parâmetros e seus graus de influência no processo de coqueificação, específicos da coqueria da Cosipa, é essencial para a sua automação e mais ainda, para a otimização do controle de processo.

\subsection{Organização da Dissertação}

Para dar uma visão clara dos problemas e da abordagem das soluções tratadas, o capítulo 2 apresenta uma descrição do processo de coqueificação e da transferência de calor dentro do forno; descreve a planta da Cosipa; apresenta exemplos de controle de outras plantas pelo mundo e faz uma análise da situação atual da planta da Cosipa, comparando-a com as demais. A descrição dos equipamentos que compreendem as baterias de fornos de coque e seus periféricos, bem como o sistema de controle do processo, tem como objetivo situar claramente o problema e, mais especificamente, os fatores e respostas do processo estudado aqui. O estudo físico-químico da carbonização do carvão dentro de um forno, também visa dar uma base mais clara da compreensão do processo de coqueificação. O relato das soluções de outras plantas tem o objetivo de mostrar a diversidade de caminhos encontrados, levando em conta as peculiaridades de cada 
uma e também os pontos convergentes.

O capítulo 3 apresenta a metodologia de experimentação utilizada nesse trabalho. Ele descreve os conceitos básicos do projeto de experimentos, de forma mais específica, o projeto de experimentos com fatorial completo. O objetivo é mostrar a robustez dos resultados obtidos com essa metodologia. O capitulo 3 mostra ainda todas as etapas do projeto de experimentos, os detalhes do forno piloto usado para os testes, o planejamento para o tratamento dos dados obtidos e a forma utilizada para garantir a confiabilidade e exatidão desses dados, ou seja, 0 delineamento do projeto de experimentos. São apresentadas as regras para a análise dos dados, tanto dos fatores quanto das respostas dos experimentos.

A descrição detalhada da execução de todo o projeto de experimentos é apresentada no capítulo 4, desde a coleta das amostras de carvões até a utilização do software Statistica para o tratamento dos dados obtidos em cada experimento e também os problemas ocorridos durante as etapas dos experimentos. Neste capítulo é descrito também o experimento em escala industrial feito em um forno da bateria 5 da Cosipa. O objetivo desse experimento foi mostrar, no forno industrial, como poderá ser feito o controle dos fatores analisados no forno teste.

Os resultados obtidos no forno teste e no forno industrial são analisados e discutidos no capitulo 5. Os gráficos e tabelas gerados pelo software Statistica são mostrados, ilustrando as análises dos números obtidos.

Finalmente, no capítulo 6 são apresentadas as conclusões do projeto de experimentos e do experimento em escala industrial bem como as futuras linhas de pesquisa. Também são relatadas as considerações finais do trabalho. 


\section{Capítulo 2 DESCRIÇÃO DO PROCESSO DE FABRICAÇÃO DO COQUE.}

\subsection{0 processo de Coqueificação}

\subsubsection{O processo físico-químico da Coqueificação}

O carvão betuminoso, chamado comercialmente de carvão metalúrgico, tem características específicas no processo de pirólise que gera o coque, produto utilizado na fabricação do ferro gusa nos altos fornos. Essa característica específica de se transformar em coque é devido a alguns componentes do carvão chamados de macerais. A quantidade desses componentes associados a outros elementos constituintes do carvão dará maior ou menor capacidade do carvão de virar o coque com as propriedades adequadas para uso em altos fornos.

O processo da pirólise do carvão passa por várias etapas que podem ser divididas em três etapas principais. A primeira etapa ocorre durante o aquecimento do carvão até $350^{\circ} \mathrm{C}$. Nessa etapa há a vaporização da umidade e o início da desvolatilização. A segunda etapa, chamada de fase plástica, ocorre entre $350^{\circ} \mathrm{C}$ e $500^{\circ} \mathrm{C}$. A decomposição do carvão em alcatrão e gases forma uma pasta que vai envolvendo as partes ainda sólidas, muitas delas sendo diluídas pelo líquido formado. A terceira etapa ocorre acima de $500^{\circ} \mathrm{C}$ e vai até o final do processo quando a temperatura atinge $1000^{\circ} \mathrm{C}$. Nessa fase a pasta perde mais material volátil e começa a endurecer e a trincar, formando o semicoque e finalmente o coque (JÜNTGEN, 1984; KOCH et al., 1995).

Loison, Foch e Boyer (1989) dividem as reações que ocorrem durante a fase plástica, basicamente, em dois tipos de reações principais. Um primeiro tipo são as reações de craqueamento com o rompimento das ligações C-C produzindo polímeros menores do que o do carvão e muitos deles em estado líquido nessas temperaturas. A saturação dos radicais formados pela ruptura das ligações C-C necessita de hidrogênio, que será suprido pelo segundo tipo de reações. Esse outro 
tipo são as reações de aromatização e condensação, que consistem na formação de cadeias aromáticas mais longas com os anéis saturados, a desidrogenização dos anéis saturados e a recombinação de grupos aromáticos com outros. Essas reações liberam hidrogênio e levam à formação de resíduo de carbono sólido. A figura 1 ilustra as reações descritas acima.

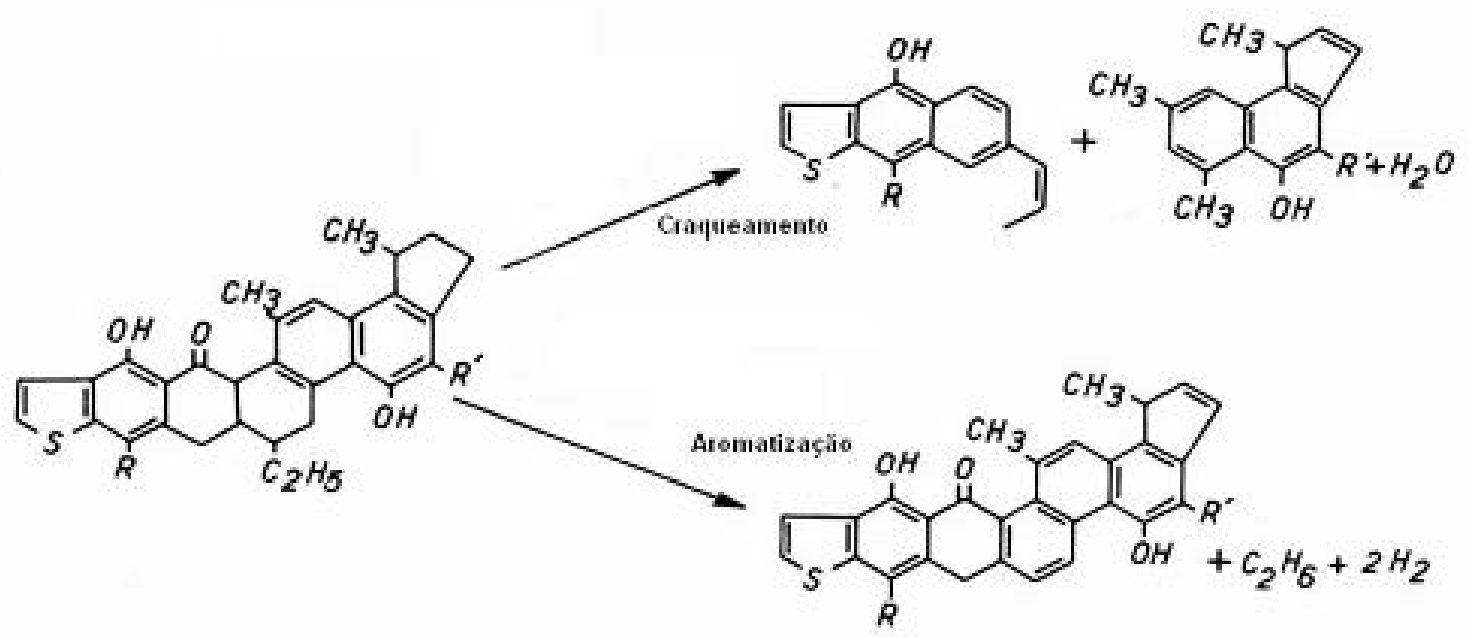

Figura 1 - Esquema dos dois principais tipos de reações de carbonização (LOISON; FOCH; BOYER, 1989).

Ainda na segunda etapa, a descrição do fenômeno de fusão do carvão pode ser dividida em quatro fenômenos elementares: o fenômeno físico de amolecimento; a formação de alcatrão líquido resultante das reações de craqueamento; a volatilização de uma fração do alcatrão formado e a dissolução do carvão durante a carbonização por uma fração do alcatrão não volatilizado (LOISON; FOCH; BOYER, 1989; FURLONG; BALDWIN; BAIN, 1982).

A terceira e última etapa do processo de coqueificação é a solidificação, que começa acima de $500^{\circ} \mathrm{C}$. Nessa etapa ocorrem as volatilizações finais e a formação do semicoque. A composição dos gases gerados vai alterando através do aumento da geração de hidrogênio e a redução da geração de metano. A temperatura vai aumentando e o semicoque se transforma no coque a uma temperatura de $950^{\circ} \mathrm{C} \mathrm{a}$ $1.000^{\circ} \mathrm{C}$. Na etapa da fase plástica há uma expansão da massa, provocando pressão nas paredes e depois, na última etapa, há a contração da massa formada. O bolo de coque, no processo industrial, ainda fica dentro do forno por um tempo, 
após a formação do coque, para homogeneizar a temperatura da massa como um todo e, com isso, equalizar as propriedades físicas e metalúrgicas do coque (KIDENA; MURATA; NOMURA, 1996; KOCH et al., 1996; AMAMOTO, 1997).

\subsubsection{A dinâmica da transferência de calor no processo de coqueificação}

O forno de coque tem o formato de um paralelepípedo nas dimensões descritas no item 2.2.1 que faz com que a transferência de calor das paredes para a carga de mistura de carvões aconteça, preferencialmente, no sentido da parede para o centro da largura do forno, podendo-se desprezar as demais direções de transferência. O processo de coqueificação ocorre de forma dinâmica dentro do forno industrial. Em primeiro lugar, a temperatura da parede de aquecimento não é constante ao longo do tempo de coqueificação. Como o aquecimento dessas paredes é feito com um fluxo constante de calor, ao enfornar uma massa fria dentro do forno, há uma queda da temperatura até chegar a um mínimo e esta volta a aumentar com o final da coqueificação. Outro aspecto importante é a dinâmica de formação da zona plástica e o fluxo do material volátil, do vapor de água e do alcatrão ao longo do processo de coqueificação. Toda essa dinâmica modifica-se ao longo do tempo e da distância da parede do forno. As várias etapas da pirólise da mistura de carvão ocorrem ao mesmo tempo ao longo da largura do forno. A fase plástica forma um envelope que vai fechando com o passar do tempo. Do lado externo do envelope forma-se o semicoque e do lado interno ainda há carvão úmido. Parte dos gases que se formam, saem pelo lado quente, ou seja, o lado externo do envelope plástico e caminham junto à parede aquecida até o topo do forno. A outra parte caminha em direção ao centro do forno e ao encontrar as partículas frias do carvão há a condensação tanto do vapor d'água quanto do alcatrão gerado. Ao final da coqueificação, o envelope se fecha no centro e toda a massa enfornada se transforma em coque. A condutividade da massa de carvão é diferente da condutividade da fase plástica e esta também é diferente da condutividade do semicoque. Como há o deslocamento do envelope plástico, a espessura de cada camada varia com o tempo e assim há uma variação dinâmica da taxa de transferência de calor ao longo do tempo e da distância em relação ao centro do 
forno. As reações de pirólise são endotérmicas até em torno de $600^{\circ} \mathrm{C}$ e exotérmicas a partir dessa temperatura (MERRICK, 1983; OSINSKI; BARR; BRIMACOMBE, 1993). Junto com esses fatores, a transferência de calor ocorre de diversas formas, por condução, convecção e radiação (LOISON; FOCH; BOYER, 1989). A figura 2 mostra um gráfico da distribuição da temperatura ao longo da largura do forno em diversos momentos da coqueificação. Na figura 2 são também identificadas as fases do processo de coqueificação.

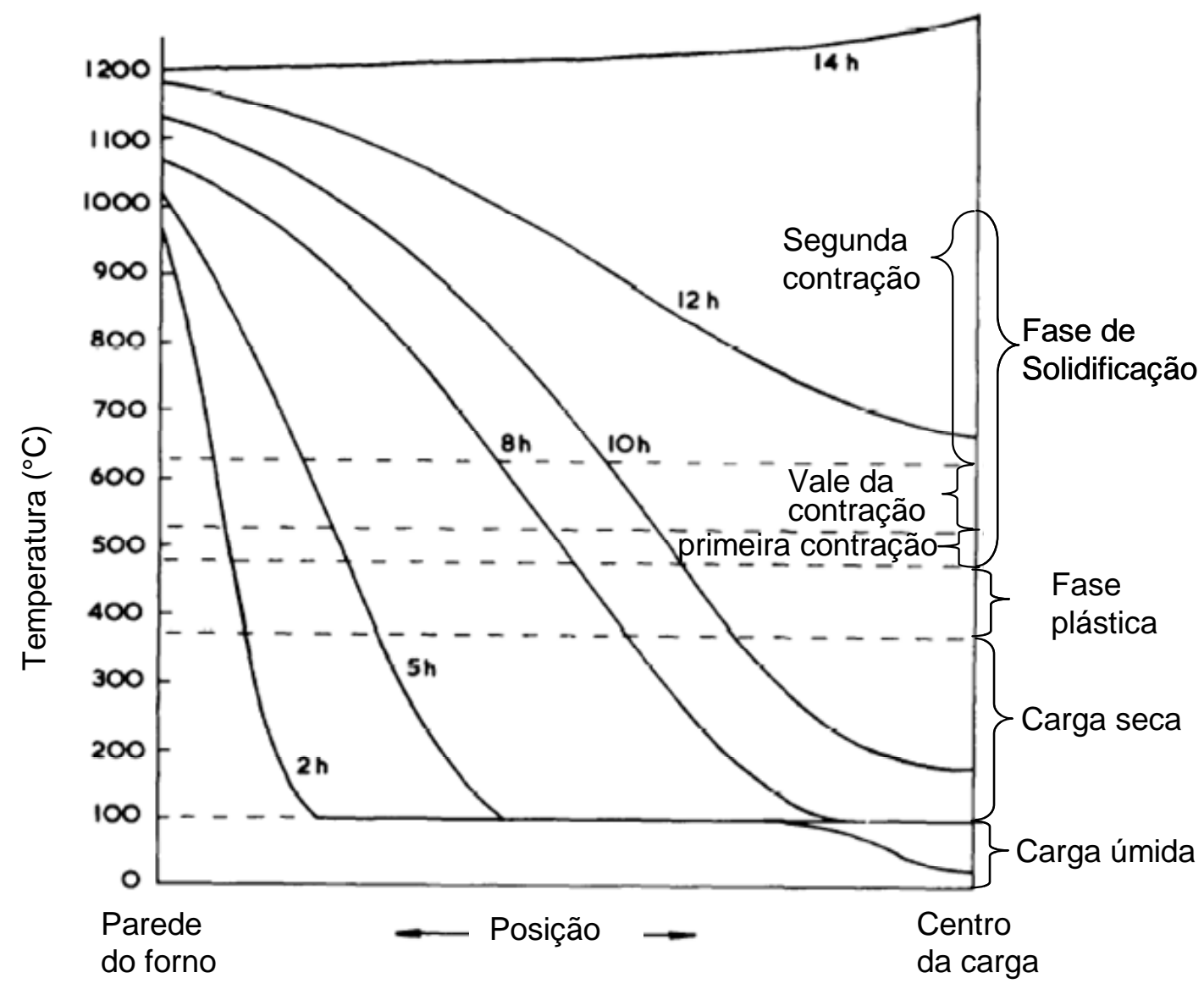

Figura 2 - Perfis de temperatura da massa de carvão enfornada em diversos momentos da coqueificação (MERRICK, 1983).

A taxa de aquecimento do carvão é alta próxima à parede de aquecimento e cai rapidamente em direção ao centro do forno. A constância da temperatura em $100^{\circ} \mathrm{C}$ no centro do forno é devido à migração do vapor d'água vindo condensar no meio do carvão ainda frio, como relatado acima. A figura 3 ilustra um corte da massa de carvão em processo de coqueificação mostrando as três principais fases desse 
processo. Ela mostra também as fissuras e poros por onde há a passagem de gases e também a transmissão de calor por radiação. A curva representa a temperatura ao longo da massa entre $1000^{\circ} \mathrm{C}$ próximo à parede do forno e $100^{\circ} \mathrm{C}$ no centro do forno.

Merrick (1983), em seu artigo, desenvolve modelos matemáticos para prever a transferência de calor da parede do forno até o centro durante todo o processo de coqueificação. Ele constrói modelos desde o desprendimento dos materiais voláteis e sua evolução, os calores específicos dos materiais envolvidos, o calor gerado ou absorvido pelas diversas reações ao longo do processo de coqueificação e as diversas formas de transferência de calor através dos materiais envolvidos e de suas porosidades.

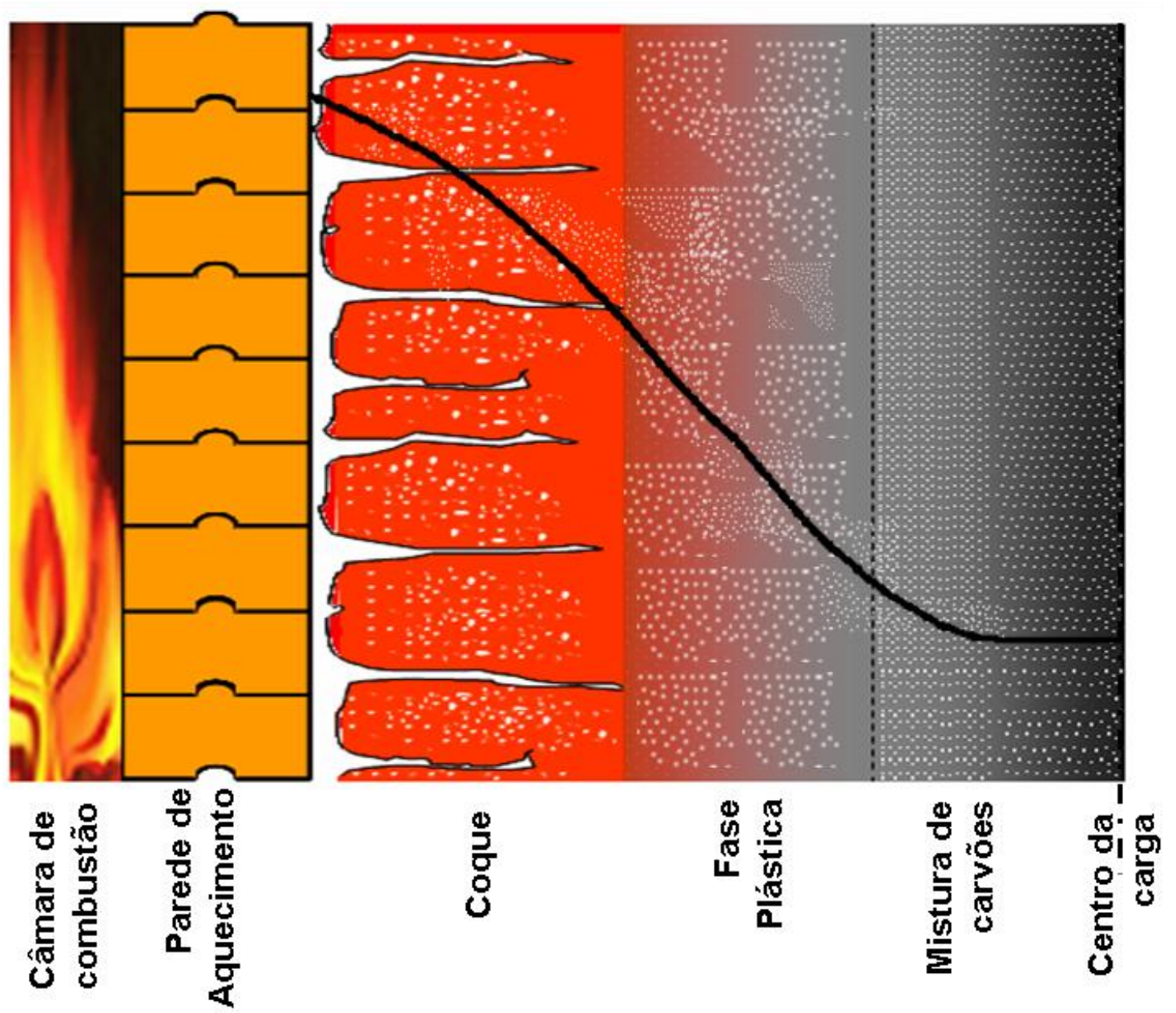

Figura 3 - Processo de coqueificação mostrado esquematicamente num corte do forno carregado e o perfil de temperatura nesse momento da coqueificação.

Para chegar aos resultados dos modelos matemáticos, Merrick (1983) teve 
que fazer várias considerações quanto aos carvões e seus comportamentos dentro do forno. No forno industrial, as variações dessas condições são grandes. No caso das partículas de carvão, há uma variação significativa, pois, a mistura enfornada, geralmente composta de 3 a 10 carvões, tem uma distribuição granulométrica muito diferenciada dependendo do perfil dessa distribuição para cada carvão. Talvez seja possível, através do conhecimento das distribuições granulométricas de cada carvão e da mistura resultante, determinar a densidade prevista e a quantidade de interstícios da carga. Mas esse tipo de análise não é possível fazer de forma rotineira no sistema industrial, que apenas faz análise granulométrica de uma ou duas peneiras devido à necessidade de rapidez nos resultados e à grande quantidade de material manuseado. Outra variação não considerada no estudo é o gradiente de densidade formado durante o carregamento do forno. Uma queda de 8 metros para a região da soleira do forno no início do carregamento e uma queda de 2 metros no final, do topo da carga, aliado ao peso da coluna de carga formada, gera esse gradiente de densidade, de forma que o comportamento da transferência de calor será diferente ao longo da altura do forno. Quanto aos interstícios gerados pelas fissuras do coque, também há uma variabilidade muito grande, pois, essas fissuras dependem de muitos fatores como a velocidade de coqueificação, a qualidade dos carvões envolvidos e a densidade da carga. Em resumo, os modelos matemáticos apresentados por Merrick (1983), apresentam boa representatividade do processo de coqueificação em um forno convencional dentro de determinadas condições específicas a uma região limitada do forno. Ao extrapolar para o restante do forno, será necessário adaptar novas condições de contorno para as diversas regiões e ao longo do tempo de coqueificação. Entretanto o seu estudo apresenta também o grau de influência de alguns fatores principais do processo de aquecimento, como a densidade aparente, a umidade da mistura, a temperatura da parede e a composição da mistura de carvões.

Merrick (1983) apresenta uma relação entre a densidade aparente e a porosidade formada pelos interstícios da fase granular da mistura de carvões antes de iniciar a fase plástica e também apresenta a relação entre essa densidade e a porosidade da fase plástica e do semicoque formado. A porosidade nas três fases da coqueificação, granular, plástica e semicoque, é de vital importância para o fenômeno de transferência de calor, seja através da convecção pelos gases formados, seja através da condução pelas partículas, ou seja pela radiação entre os 
interstícios, as trincas e os poros. Merrick (1983) também mostra uma grande influência da umidade da carga na transferência de calor. Durante toda a coqueificação, o vapor formado escapa, junto com as matérias voláteis, tanto pelo lado interno da carga e nesse caso há a contínua condensação e evaporação enquanto houver carvão frio, quanto pelo lado do semicoque formado e nesse caso há a dissociação do vapor devido às altas temperaturas (VYAS et al., 2004). Mas um fator difícil, nesse caso, é precisar qual a quantidade de vapor seguiu um dos dois caminhos, pois, para cada um o calor transferido será diferente. O mesmo raciocínio pode ser feito para os materiais voláteis formados, pois eles terão comportamento e interferência nas transferências de calor diferentes dependendo do caminho que tomarem para o topo do forno.

Através dos modelos matemáticos de transferência de calor, Merrick (1983), dentro das limitações descritas acima, conseguiu estimar o tempo líquido de coqueificação e quantidade de calor para a coqueificação. Lia (1987), em sua dissertação de mestrado, desenvolve um trabalho de modelamento semelhante ao de Merrick e apresenta algumas equações que serão utilizadas nesse trabalho para comparar com os resultados obtidos pelos experimentos.

\subsection{As Baterias de Fornos de Coque da COSIPA}

\subsubsection{A Estrutura das Baterias}

A Companhia Siderúrgica Paulista, Cosipa, é uma siderúrgica integrada a coque, com produção anual em 2006 de 4,3 milhões de toneladas de aço. A planta de fabricação do coque, a coqueria, produz anualmente 1,6 milhões de toneladas de coque, 620.000 dam $^{3}$ de gás de coqueria, 41.000 ton de alcatrão e 11.400 ton de óleos leves.

Os fornos do Grupo 1 têm volume útil de 22,02 $\mathrm{m}^{3}, 12,23$ metros de comprimento, 4 metros de altura e largura entre 0,42 e 0,48 metros, pois, existe uma conicidade ao longo do comprimento do forno de 0,06 metros para facilitar o desenfornamento. Os fornos têm quatro bocas de carga no topo e um tubo de 
ascensão, por onde são coletados os gases gerados durante a coqueificação. Esses gases são refrigerados de uma temperatura média de $600^{\circ} \mathrm{C}$ para $80^{\circ} \mathrm{C}$ na curva do tubo de ascensão e depois conduzidos por tubulação até a unidade de tratamento carboquímico. As baterias 1 e 2 têm, cada uma, 31 fornos intercalados entre 32 paredes de aquecimento. A Bateria 3 tem 35 fornos entre 36 paredes de aquecimento. A parede de aquecimento é composta de 28 câmaras de combustão, numeradas de 1 a 28 do lado da desenfornadora (LD) para o lado da saída do coque (LC). Essas câmaras têm comunicação com os regeneradores abaixo delas e estes, por sua vez, têm comunicação com as tubulações de gás, com as entradas de ar e com as saídas de fumaça para a chaminé. O canal de fumaça fica situado na parte inferior da bateria no LC e as entradas do gás e do ar ficam situadas num nível acima do canal de fumaça no LD. Uma chaminé de 88 metros de altura recebe a fumaça das três baterias. A torre que abastece as máquinas enfornadoras tem capacidade de armazenar 1.800 ton de carvão. Uma correia transportadora alimenta a torre com a mistura de carvões vinda dos silos dosadores do pátio de carvões. Esse grupo de baterias tem uma torre de extinção do coque depois de desenfornado. A extinção é feita com água que, parte é transformada em vapor e parte retorna para um tanque de decantação, de onde é bombeada de volta para os tanques superiores. Um sistema de reposição de água mantém o tanque de decantação sempre no nível de trabalho.

Os fornos do Grupo 2 têm 6 metros de altura, 15 metros de comprimento e 0,43 metros de largura média com conicidade de 0,06 metros, perfazendo um volume útil de $37,36 \mathrm{~m}^{3}$. O topo dos fornos destas baterias também tem quatro bocas de carregamento e um tubo de ascensão. As paredes de aquecimento têm 30 câmaras de combustão, numeradas de 1 a 30 do LD para o LC. A torre de carvão dessas baterias tem capacidade para 2.000 toneladas de carvão e também é alimentada por correia transportadora dos silos dosadores do pátio de carvões. Existem duas torres de extinção que atendem a esse grupo de baterias. Uma torre, exclusiva desse grupo, ao sul das baterias e uma outra ao norte que também pode ser usada pelas baterias do Grupo 1. Os dados principais das baterias da Cosipa estão detalhados na tabela 2.1. Cada bateria tem uma chaminé de 108 metros de altura e um canal de fumaça que circunda toda a bateria em forma de anel. Tanto do lado do coque quanto do lado da desenfornadora tem caixas de entrada de ar e gás e também para receber a fumaça. Essas caixas fazem a ligação entre os 
regeneradores e o canal de fumaça. A figura 4 ilustra uma bateria típica de projeto igual às baterias do Grupo 2, mostrando em corte os detalhes de uma bateria de fornos de coque.

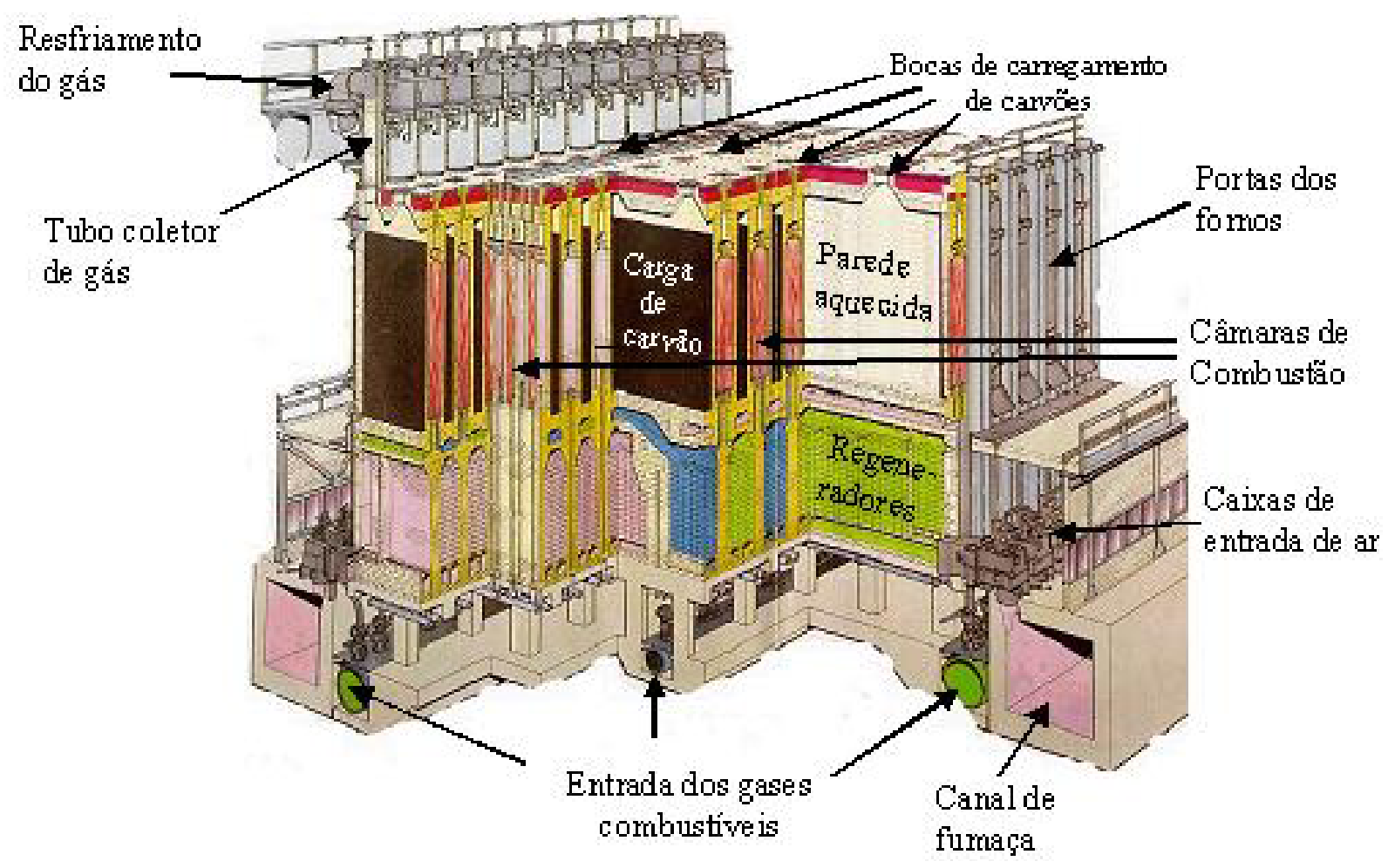

Figura 4 - Bateria de fornos de coque de projeto Krupp Koopers.

Tabela 2.1 - Dados operacionais das baterias de fornos da Cosipa

\begin{tabular}{lccccc}
\hline \multicolumn{1}{c}{ Parâmetro } & Bateria 1 & Bateria 2 & Bateria 3 & Bateria 4 & Bateria 5 \\
\hline Ano Partida & 1965 & 1965 & 1972 & 1976 & 1983 \\
\hline Fabricante & CEC & CEC & CEC & KK & KK \\
\hline Altura & $4 \mathrm{~m}$ & $4 \mathrm{~m}$ & $4 \mathrm{~m}$ & $6 \mathrm{~m}$ & $6 \mathrm{~m}$ \\
\hline Comprim. & $12,2 \mathrm{~m}$ & $12,2 \mathrm{~m}$ & $12,2 \mathrm{~m}$ & $15 \mathrm{~m}$ & $15 \mathrm{~m}$ \\
\hline Largura (m) & $0,42 \mathrm{a} \mathrm{0,48}$ & $0,42 \mathrm{a} \mathrm{0,48}$ & $0,42 \mathrm{a} \mathrm{0,48}$ & $0,40 \mathrm{a} \mathrm{0,46}$ & $0,40 \mathrm{a} \mathrm{0,46}$ \\
\hline N. fornos & 31 & 31 & 35 & 53 & 53 \\
\hline Produção & 500.000 ton/ano & & 1.100 .000 ton/ano \\
\hline
\end{tabular}




\subsubsection{O sistema de aquecimento dos fornos}

Os gases combustíveis utilizados no aquecimento dos fornos das baterias da Cosipa são: o gás de coqueria (GCO), gerado pela própria bateria e limpo na unidade carboquímica e o gás de alto forno (GAF), gerado pelos altos fornos. O GAF tem um poder calorífico inferior $(\mathrm{PCl})$ em torno de 750 a $900 \mathrm{kcal} / \mathrm{Nm}^{3}$ e o GCO, entre 4.000 e $4.500 \mathrm{kcal} / \mathrm{Nm}^{3}$. As baterias utilizam normalmente um gás formado pela mistura desses dois gases com um PCl em torno de 1.000 a 1250 $\mathrm{kcal} / \mathrm{Nm}^{3}$, o gás misto (GM). Quando se queima GCO puro nas baterias, este não entra pelos regeneradores, mas por um duto direto na base da câmara de combustão (baterias do tipo "underjet"). Isto é devido ao fato do gás de coqueria ter hidrocarbonetos (em torno de 30\%) que podem craquear dentro dos regeneradores, deixando resíduos que obstruem os seus tijolos grelhas. Um sistema composto de cilindros hidráulicos, barramentos metálicos, válvulas de gás, caixas de entrada de ar e gás e pistões dos canais de fumaça faz a reversão da queima entre as câmaras de combustão. A figura 5 mostra esquematicamente o funcionamento das reversões operadas por um sistema hidráulico. Nesse desenho esquemático as câmaras impares estão em queima e as câmaras pares estão em circulação de fumaça.

A cada vinte minutos, metade das câmaras de cada parede recebe ar e gás, queimam e a fumaça resultante passa para as câmaras adjacentes por uma comunicação na parte superior das câmaras e esta vai para os canais de fumaça através de orifícios abertos pelos pistões da caixa de fumaça e, finalmente, para a chaminé. Após os 20 minutos, o sistema de reversão inverte a situação e nas câmaras onde havia circulação de fumaça, passa a entrar ar e gás e a queimar e as câmaras que estavam queimando, começam a receber a fumaça. Entre as câmaras de combustão e as entradas de ar e gás e as saídas de fumaça, existem os regeneradores, cuja função é trocar o calor da fumaça com o ar e o gás. Quando a fumaça, a $1.200^{\circ} \mathrm{C}$, passa pelos regeneradores ocorre a transferência de calor e conseqüente aquecimento dos tijolos do regenerador, saindo essa fumaça na chaminé a $220^{\circ} \mathrm{C}$, deixando estes aquecidos. Na próxima reversão, os tijolos grelhas cedem seu calor para o ar e o gás que passam pelos regeneradores no sentido inverso. Nas baterias 1, 2 e 3, abaixo de cada forno tem dois regeneradores paralelos ao longo do comprimento do forno. Esses regeneradores têm dutos de 
comunicação com as paredes de um lado e do outro do forno acima deles. Numa reversão, um par de regeneradores está com ar e gás e os pares adjacentes a este estão com fumaça. Nas baterias 4 e 5, os regeneradores sob cada forno são divididos em dois. Um, do lado da desenfornadora (LD), que vai até a metade do comprimento do forno e continua com um duto menor acima do outro regenerador do lado do coque (LC), que, por sua vez, ocupa a outra metade abaixo do forno e também tem um duto sobre o regenerador do LD. Os regeneradores do LD alimentam as câmaras pares e os do LC alimentam as câmaras ímpares das paredes adjacentes ao forno acima dos regeneradores.

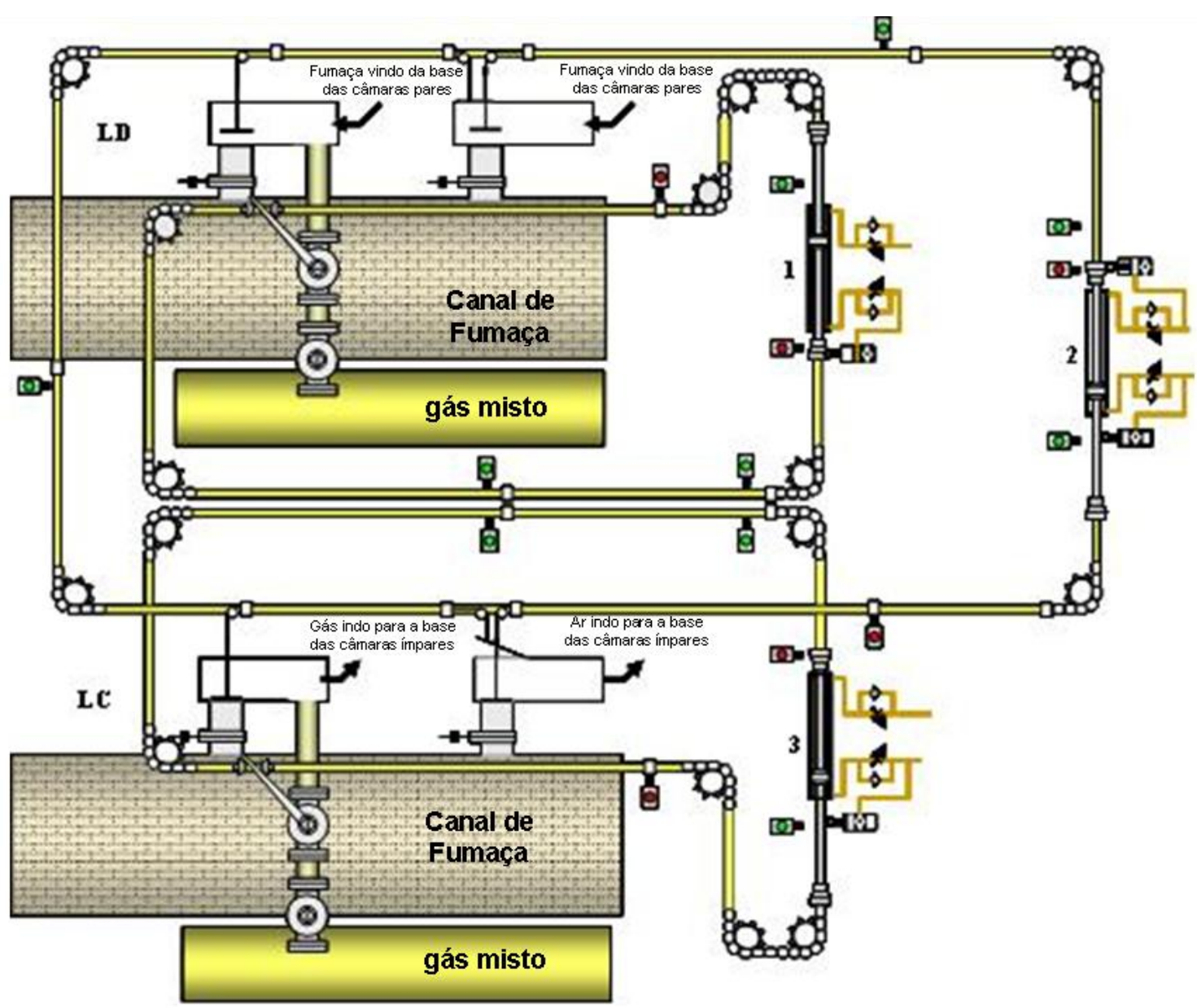

Figura 5 - Desenho esquemático do sistema de reversão do Grupo 2.

O sistema de aquecimento das baterias 1 e 2 é separado do da bateria 3, tendo em comum apenas a chaminé. As baterias 4 e 5 têm um sistema de mistura de gases comum e o controle de fluxo dos gases e a chaminé individualizados. 


\subsubsection{A operação dos fornos}

Cada grupo de baterias tem dois conjuntos de máquinas móveis que fazem a operação de enfornamento, desenfornamento e apagamento do coque. A máquina enfornadora é composta de quatro conjuntos de silo, parafuso alimentador, moega de queda e sistema de abertura e fechamento das bocas de carregamento dos fornos. A capacidade dos silos é pouco maior do que a de um forno, de forma que, ao enfornar, sobra uma quantidade mínima que faz a selagem entre a boca de carga e o silo da máquina, evitando o retorno de gás pelas moegas. Cada silo tem balança que faz o controle da quantidade enfornada. O ciclo operacional da máquina enfornadora compreende o carregamento da máquina na torre de carvão, posicionamento sobre o forno a ser enfornado, abertura das bocas de carga do forno com eletroímãs, encaixe das moegas dos silos sobre as bocas em seqüência de 1 a 4 e o giro dos parafusos provocando a queda do carvão no forno. Durante esse processo, o forno está com pressão negativa provocada por injeção de água amoniacal a alta pressão (30 kgf/cm $\left.{ }^{2}\right)$ na curva do tubo de ascensão, com o objetivo de evitar o vazamento dos gases produzidos no interior do forno. Quando o forno está com $80 \%$ de sua carga enfornada, a máquina enfornadora interrompe 0 carregamento e a máquina desenfornadora introduz, por uma portinhola da porta do LD, uma barra niveladora na região superior do forno. Após a introdução completa da barra, a máquina enfornadora volta a jogar o restante do carvão estipulado para aquele forno, enquanto a barra niveladora fica, num movimento de vai e vem, nivelando a carga de carvão dentro do forno. Ao final do carregamento, a barra niveladora é retirada e a portinhola é fechada. A máquina enfornadora retira as moegas das bocas de carga, recoloca suas tampas e retorna para a torre de carvão. As tampas das bocas de carga são, depois, vedadas com uma massa à base de argila e cal e a água amoniacal a alta pressão que induz a depressão no interior do forno é fechada. Essa massa de carvão fica entre 14 e 24 horas dentro do forno até completar o processo de coqueificação e de estabilização do coque formado.

Ao final da coqueificação o forno é isolado do coletor de gás por uma válvula no tubo de ascensão e está pronto para ser desenfornado. A máquina desenfornadora se posiciona na frente do forno, abre a porta LD, encosta o êmbolo empurrador no coque e aguarda o alinhamento das demais máquinas. O carro de 
transferência de coque (CTC) abre a porta LC e posiciona a gaiola, que conduz 0 coque sobre a plataforma de serviço, até o vagão do carro apagador, sob uma coifa que faz a sucção do pó e gases remanescentes durante o desenfornamento. O carro apagador posiciona-se sob a gaiola e a máquina desenfornadora começa a empurrar o coque. Após a queda de todo coque no vagão, o carro apagador se dirige à torre de extinção, onde é feito o apagamento do coque, e finalmente este é jogado numa rampa para ser transportado por correias até os altos fornos. As máquinas desenfornadora e CTC fazem a limpeza do batente da porta do forno e da própria porta e fecham novamente o forno, que fica pronto para o próximo enfornamento.

A seqüência de desenfornamento é feita em séries de fornos denominada 13524, ou seja, a série 1, que compreende os fornos 1, 6, 11..., vem na frente, seguida da série 3 , que compreende os fornos $3,8,13 \ldots$ e assim sucessivamente até voltar para a série 1 novamente. Cada ciclo de máquina, do desenfornamento de um forno até o início do desenfornamento do próximo forno dentro da série, dura 8 minutos. Para se atingir o número diário de fornos objetivado pelo índice operacional, é ajustado o tempo entre as séries ao longo de um ciclo de coqueificação. O ciclo de coqueificação é o tempo gasto entre o desenfornamento de um forno e o próximo desenfornamento deste mesmo forno. O tempo entre o enfornamento e o desenfornamento de um mesmo forno é chamado de tempo bruto de coqueificação. O tempo líquido de coqueificação é definido como o período entre o enfornamento e o final do processo de coqueificação, ou seja, quando toda fase plástica se transformou em coque. O período restante para completar o tempo bruto de coqueificação, chamado de tempo de supercoqueificação ou stay time, é aquele tempo extra para equalizar toda massa de coque descrita no item 2.1.1.

\subsection{O sistema de controle das Baterias de Fornos de Coque}

\subsubsection{O sistema de controle atual das Baterias da Cosipa}

As baterias recebem o gás de alto forno (GAF) à pressão de 500 mmca e 
reduzem essa pressão para $350 \mathrm{mmca}$ antes de misturar com o GCO. O GCO é injetado a 600 mmca nas baterias 1, 2 e 3 e a 900 mmca nas baterias 4 e 5 . O controle de injeção é feito através de válvula controladora de vazão do GCO a ser injetado cujo valor objetivado é função da vazão de GAF consumida e do PCl dos gases envolvidos, calculado pela seguinte fórmula:

$$
\operatorname{Vobj}_{G C O}=\frac{P C I_{G C O}-P C I_{G A F}}{P C I_{G C O}-P C I_{G M}} \cdot V_{G A F}
$$

onde $\operatorname{Vobj}_{G C O}$ é a vazão objetivada de $\mathrm{GCO}, \mathrm{PCl}_{\mathrm{GCO}}, \mathrm{PCl}_{\mathrm{GAF}}$ e $\mathrm{PCl}_{\mathrm{GM}}$ são o poder calorífico inferior dos gases GCO, GAF e GM, respectivamente, cujos valores são inseridos manualmente no CLP de controle a cada uma hora se houver modificação desses valores e $V_{\mathrm{GAF}}$ é a vazão de GAF medida.

O controle de fluxo térmico das baterias, mostrado na figura 6 , calculado pela vazão de GM (gás misto) multiplicado pelo seu $\mathrm{PCl}$, é feito indiretamente pelo controle da pressão de consumo da tubulação logo abaixo das válvulas do sistema de reversão. Entre essa tubulação e as caixas de gás de entrada nos regeneradores existem duas válvulas, uma de bloqueio, com escala de regulagem de abertura e outra de reversão, que é aberta e fechada pelo sistema de reversão. Para alterar o fluxo térmico objetivado, pode-se alterar a pressão da tubulação, o $\mathrm{PCl}$ do $\mathrm{GM}$ ou a abertura das válvulas de bloqueio. As duas primeiras opções são ações de emergência feitas pelos operadores do turno e a terceira é feita quando há grandes alterações ou regulagem do sistema de queima das baterias.

O controle da combustão é feito pelo controle da tiragem da chaminé e pelo monitoramento do teor de oxigênio na fumaça na base da chaminé. Além do controle dinâmico feito pela válvula controladora de pressão da chaminé, há a rotina de regulagem individual das paredes de aquecimento através de válvulas manuais na interligação da caixa de fumaça com o canal de fumaça. A regulagem é feita com auxílio de manômetro e analisador de gases, que analisa o teor de $\mathrm{CO}, \mathrm{CO}_{2}$ e $\mathrm{O}_{2}$ da fumaça no interior das caixas de reversão.

Para manter a pressão interna dos fornos sempre positiva, o coletor de gás gerado pela bateria é controlado à pressão de 6 mmca nas baterias 1,2 e 3 e 12 mmca nas baterias 4 e 5 . Cada coletor tem uma válvula borboleta que faz essa 
função.

O sistema de controle de todas as baterias é centralizado em uma sala de controle fora das baterias. Ele é constituído de quatro CLPs Hitachi que fazem o controle das baterias 1 e 2, bateria 3, bateria 4 e bateria 5 . Alguns controles comuns estão alocados em dois CLPS, mas o controle é feito apenas a partir de um deles e uma chave pode fazer a comutação desse controle para outro CLP. Os CLPs estão em rede ethernet com 4 estações de trabalho; duas dedicadas aos CLPs das baterias 1,2 e 3 e duas dedicadas aos CLPs das baterias 4 e 5. Essas estações possuem o software supervisório Wiscon que faz a supervisão, interface com o operador e armazenamento dos dados. Uma outra estação coleta dados das estações do supervisório para um banco de dados para confecção de relatórios. Os dados operacionais não incorporados a esse sistema de controle são inseridos manualmente em planilhas numa estação interligada com a rede corporativa da empresa. Estes são os dados de horário de enfornamento e desenfornamento, controle do tempo de coqueificação e controle da carga enfornada, que geram o controle de produção das baterias, e também são inseridos os dados para o controle da temperatura média das baterias medidas manualmente com pirômetro de radiação infravermelho. A figura 6 mostra esquematicamente os diversos instrumentos de controles existentes atualmente nas Baterias da Cosipa.

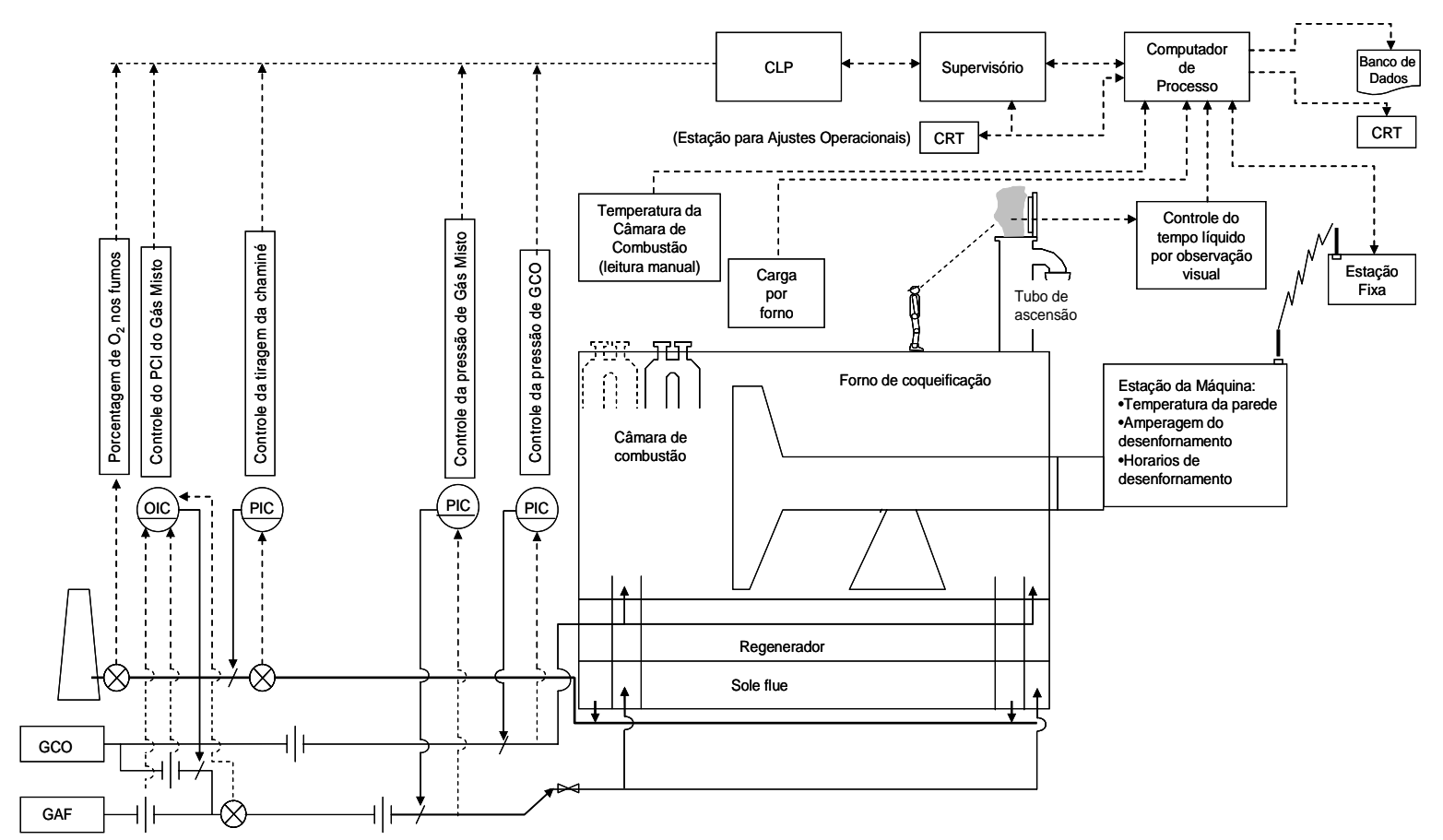

Figura 6 - Sistemas de controle das baterias de fornos de coque da Cosipa. 
O controle do processo de coqueificação na Cosipa é feito por dois parâmetros principais: a temperatura média das baterias e a observação visual dos fornos para determinação do tempo líquido de coqueificação. A temperatura média é obtida pela leitura da temperatura da base das câmaras de combustão piloto. Essa leitura é feita em todas as paredes de aquecimento de cada bateria uma vez por turno através de pirômetro de radiação infravermelho. A observação do tempo líquido é feita abrindo-se o tubo de ascensão no final da coqueificação, após isolá-lo do coletor de gases. A fumaça mais branca e transparente indica o final do processo de coqueificação. Essa observação é feita em todos os fornos. Tanto os dados da temperatura média quanto os do tempo líquido são digitados em planilhas que geram gráficos de controle para auxiliar as tomadas de ações para corrigir os desvios.

O controle da quantidade de calor injetado nas baterias é feito de acordo com o acompanhamento dos gráficos de controle de temperatura e de tempo líquido de coqueificação. Quando há atraso no ciclo operacional, há regras para calcular a quantidade de calor a ser retirada do fluxo térmico de acordo com o tempo de parada. Quando há variação da umidade da mistura de carvões, porém, as ações de gás são feitas pela experiência do operador ou após essa variação da umidade afetar a temperatura média das baterias ou o tempo líquido de coqueificação. Em todas as ações acima, a quantidade de calor a ser retirada é fruto da experiência do operador e este sempre atua com uma margem de segurança para evitar temperatura muito alta ou aumento do tempo líquido de coqueificação que interfira na produção de coque.

\subsubsection{O sistema de controle existente em outras plantas}

A abordagem adotada pelas empresas siderúrgicas para o sistema de controle de coqueificação é diversificada tanto quanto a forma de controle quanto ao modo de sensoriamento do processo. Abaixo são apresentados alguns sistemas que representam de forma geral os vários seguimentos de controle adotado pelas empresas.

a) O sistema ACC da NSC, Japão (NAKAZAKI et al., 1987; SADAKI; 
TANAKA; NAGANUMA, 1993): A Nippon Steel Corporation desenvolveu, na maioria de suas plantas de coqueria, um sistema abrangente de controle da coqueificação que denominaram "Automatic Coking Control" (ACC). A figura 7 mostra de forma esquemática os vários pontos de controle da bateria de fornos de coque, reunidos em três grupos, sendo o controle da temperatura média das câmaras de combustão, o controle do tempo líquido de coqueificação e o controle do fluxo de gás de aquecimento. O sistema compreende a monitoração e controle de vários pontos do processo de coqueificação e do sistema de aquecimento.

O controle de coqueificação é feito com o monitoramento da temperatura do gás de coqueria gerado através de termopar no tubo de ascensão. A temperatura atinge um valor máximo no final da coqueificação e depois cai. O tempo decorrido do momento do enfornamento até atingir essa temperatura máxima é chamado de T $_{\text {MAX }}$. O tempo líquido de coqueificação é obtido pela equação:

$$
\text { Tempo Líquido }=\mathrm{A} \cdot \mathrm{T}_{\mathrm{MAX}}+\mathrm{C}
$$

onde A e C são parâmetros obtidos experimentalmente, através da comparação com o método de determinação do tempo líquido por visualização da coloração do gás gerado na saída do tubo de ascensão e são característicos para cada forno da bateria.

A NSC também desenvolveu uma equação matemática para prever o tempo líquido dos próximos blocos a serem desenfornados e com esses dados fazer a correção da temperatura média objetivada das paredes de aquecimento da bateria.

$$
T_{H i}=\alpha \cdot \theta_{i}+\Delta T_{i}+\beta \cdot P_{i}+D_{i}+C
$$

onde $T_{H i}$ é o tempo líquido de coqueificação, $\theta$ é o valor médio das temperaturas das câmaras de combustão num momento específico após o enfornamento, P é o parâmetro que representa as propriedades físicas da mistura de carvões (umidade, por exemplo), $\Delta T_{i}$ é um valor estimado do elemento inerente dentro do bloco, $\mathrm{D}_{\mathrm{i}}$ é um valor estimado dos elementos que são comuns em toda bateria e muda com o tempo, $\alpha$.e $\beta$ são coeficientes do tempo líquido, C é uma constante e i é cada bloco do plano de desenfornamento. O modelo trabalha com dados históricos de blocos 
anteriores e com os valores da temperatura média obtida para prever o tempo líquido do próximo bloco. A correção da variação da temperatura para atender ao tempo líquido objetivado no caso de desvio da previsão é limitada a um valor $\Delta \theta$ máximo, ou seja, a ação da correção do tempo líquido com a temperatura média das câmaras de combustão é limitada a um valor específico, evitando descontroles inesperados. A figura 8 apresenta o diagrama de blocos para o modelo completo de controle do tempo líquido.

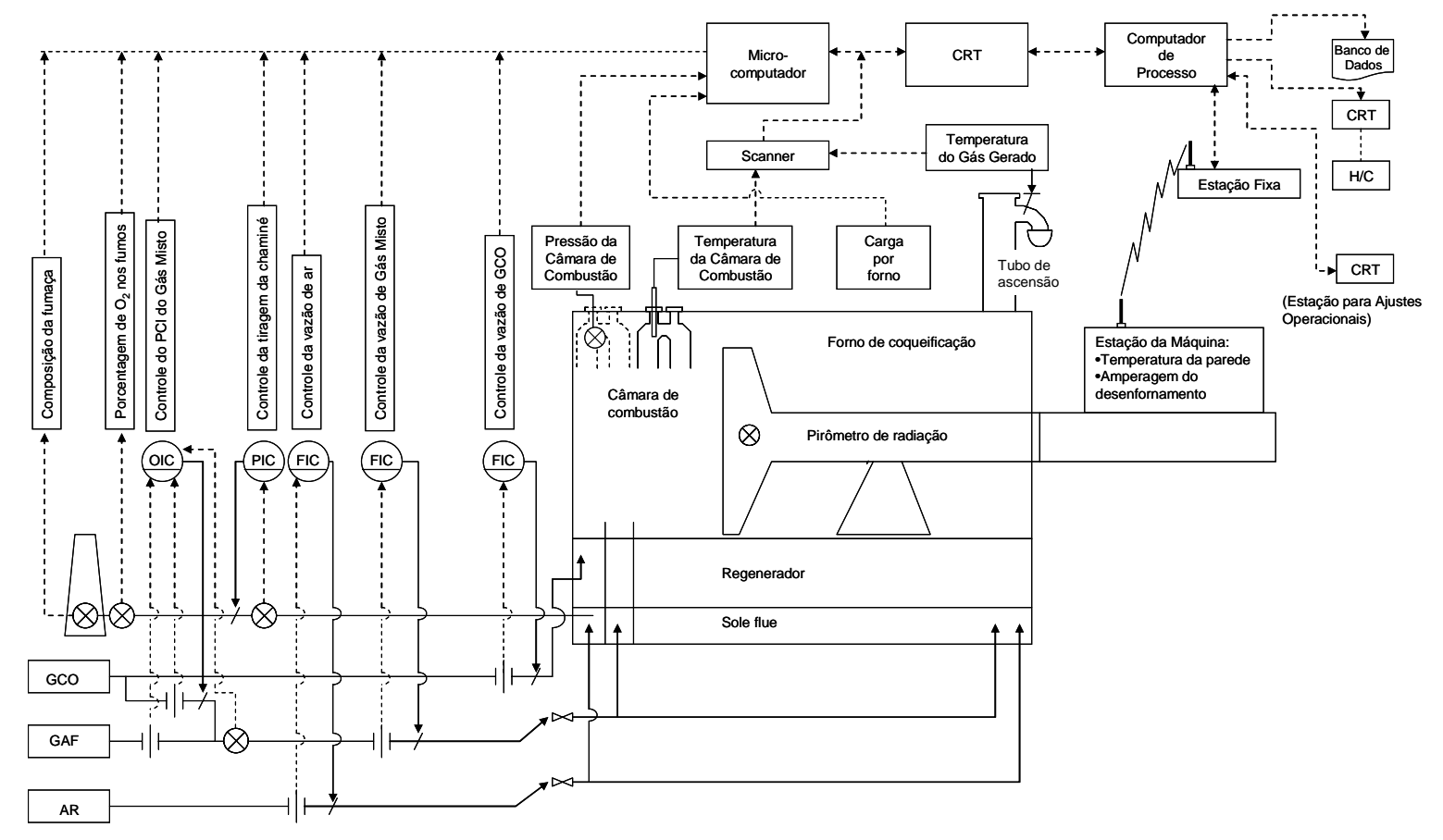

Figura 7 - Configuração básica do sistema ACC.

O controle da temperatura média da bateria é composto de dois sistemas de medição. Um sistema é composto de termopares colocados em câmaras piloto em cada parede de aquecimento, localizado na ligação superior das câmaras de combustão. O outro é a leitura da temperatura das paredes laterais dos fornos durante o desenfornamento através de três pirômetros infravermelhos localizados no êmbolo da barra desenfornadora. Durante o desenfornamento é lida a temperatura continuamente em três níveis de altura da parede. Esse último sistema é utilizado para acerto individual da temperatura em cada câmara de combustão, objetivando a melhor homogeneidade na distribuição de temperatura ao longo da parede, respeitando a diferença de temperatura em função da conicidade do forno. Já o 
primeiro sistema é utilizado no controle da temperatura média das baterias e no sistema de controle do tempo líquido, através da variação do fluxo de calor para o aquecimento das baterias.

O controle do fluxo de calor de aquecimento é composto de controle de mistura de gás de coqueria no gás de alto forno para compor o gás misto num $\mathrm{PCl}$ determinado, do controle de fluxo do gás misto e ar e o controle da combustão. $\mathrm{O}$ controle da combustão é feito com o acerto da tiragem da chaminé, com correção da relação de vazão de entrada de ar e gás, com o monitoramento do teor de oxigênio e monóxido de carbono na fumaça.

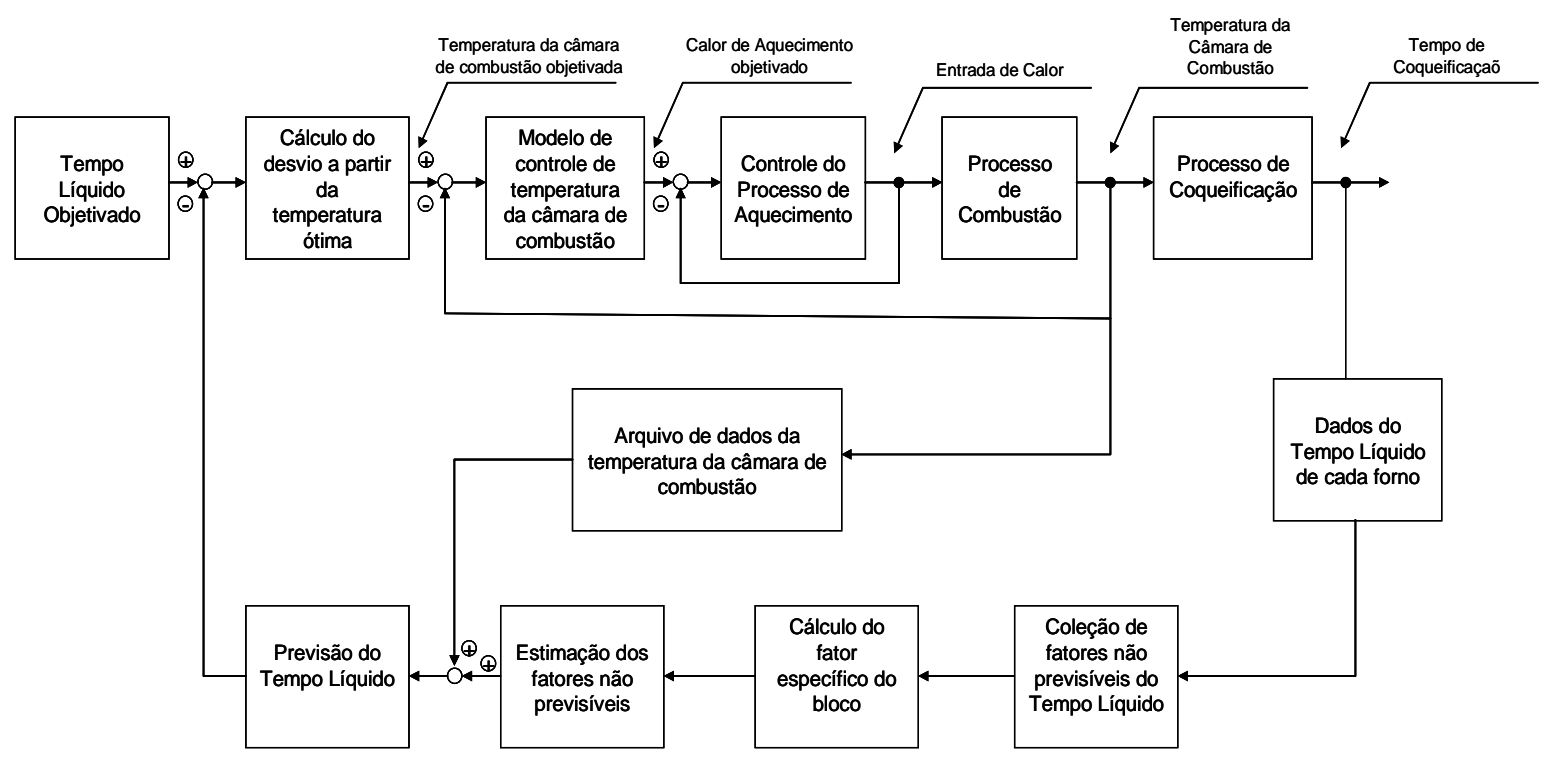

Figura 8 - Modelo do Controle de Coqueificação da NSC.

b) O sistema da Sidmar, Bélgica (HOLLE et al., 1992; MALINA, 1993): O controle de injeção do calor de aquecimento das baterias da Sidmar é feito através do controle de pausa da reversão, ou seja, mantém-se uma vazão constante dos gases combustíveis e varia o tempo de pausa a cada reversão de queima nas câmaras de combustão. Foi desenvolvida uma equação matemática para determinar o tempo de queima em cada reversão que ocorre periodicamente a cada vinte minutos. 


$$
t=25 \cdot \frac{E \cdot n \cdot G_{D}}{H_{u} \cdot Q}
$$

onde $\mathrm{t}$ - tempo de queima por reversão de cada bateria (s), E- energia específica por tonelada de carvão seco enfornado (GJ/t), n - número total de desenfornamentos por dia, $G_{D}$ - carga por forno média (ton), $H_{u}$ - poder calorífico do gás de aquecimento $\left(\mathrm{GJ} / \mathrm{Nm}^{3}\right)$ e $\mathrm{Q}$ - fluxo de gás por bateria $\left(\mathrm{Nm}^{3} / \mathrm{h}\right)$. O fator $E$ foi determinado empiricamente por processamento estatístico de dados coletados pelas experiências históricas. Ele é dado em tabela de acordo com a estação do ano e a umidade da mistura de carvões, principalmente. O controle de coqueificação é feito com o monitoramento da temperatura do gás de coqueria gerado, através do Índice de Coqueificação, cuja fórmula é:

$$
C I=\frac{t_{C}}{t_{\max }}
$$

onde $\mathrm{Cl}$ é o Índice de Coqueificação, $\mathrm{t}_{\mathrm{c}}$ é o tempo total de coqueificação ou tempo bruto, em minutos e $t_{\max }$ é o tempo decorrido entre o enfornamento e momento de máxima temperatura do gás de coqueria gerado em minutos. A figura 9 ilustra 0 sistema de controle da Sidmar, mostrando os controles existentes.

O controle da temperatura média da bateria é feito pelo monitoramento da leitura da temperatura da base das câmaras de combustão, obtida manualmente com pirômetros de radiação infravermelhos e também pelo monitoramento da temperatura da superfície do coque no momento do desenfornamento. Esse monitoramento é feito através de pirômetros colocados na guia de coque e transmitidos via rádio para a sala de controle. Todos os dados obtidos no processo são transmitidos para um computador central $\mu \mathrm{VAX}$. Esse computador produz tabelas e gráficos dos dados que são então analisados pelos engenheiros e supervisores do processo. Caso tenha desvios, toma-se ação de correção no tempo do ciclo de reversão ou no fluxo de gás ou no $\mathrm{PCl}$ do gás ou até numa combinação dessas ações.

c) O sistema CETCO da Corus, Holanda (VANDER; Van BALLEGOOIE; VOS, 1990): O sistema CETCO da Corus é baseado na temperatura final do coque, por isso o nome CET (coke end temperature). Outra característica do controle de 
aquecimento das baterias desse sistema é o uso de termopares na massa refratária sobre os regeneradores como sensores da temperatura da bateria, ao invés da temperatura da câmara de combustão, mais comumente utilizada.

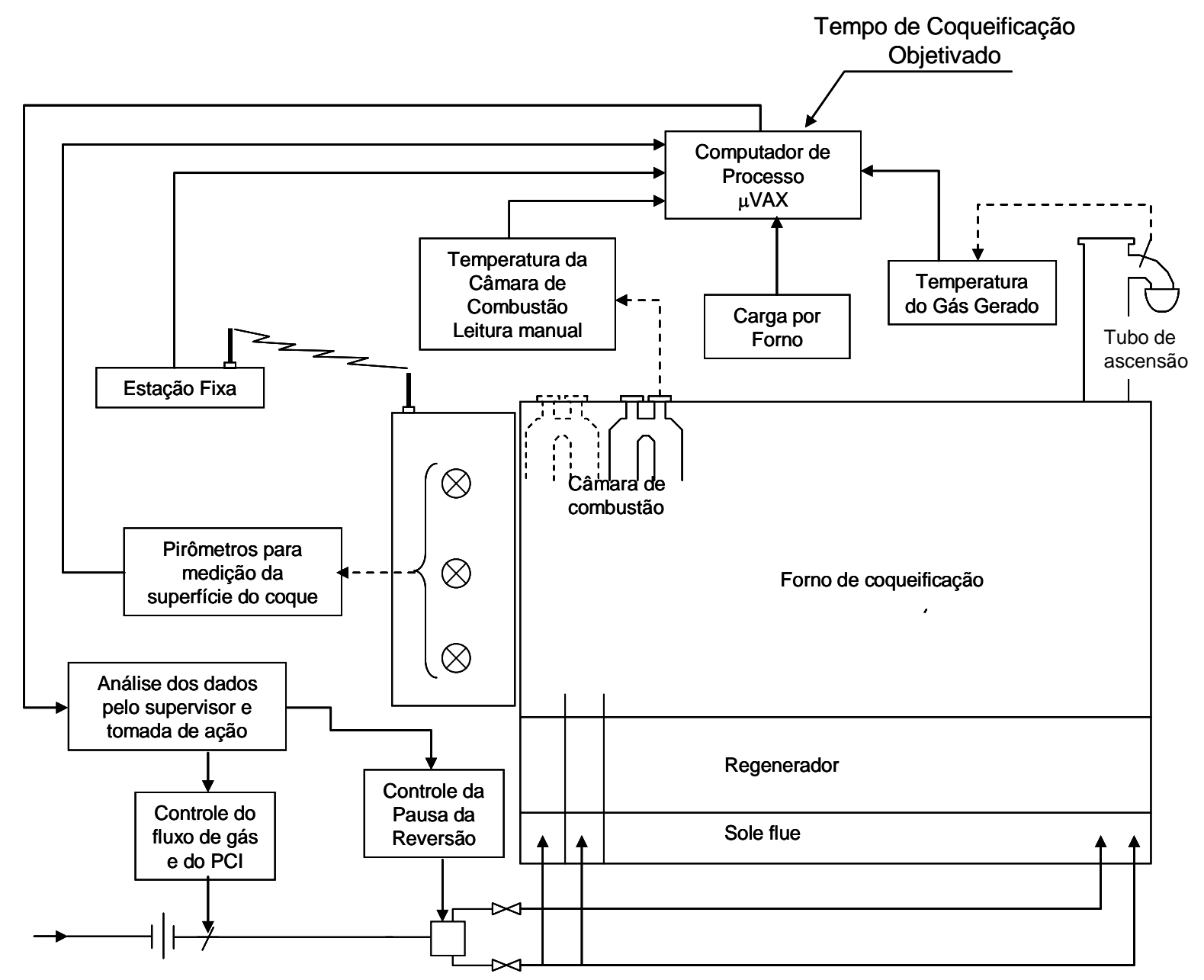

Figura 9 - Sistema de controle de coqueificação da Sidmar.

O controle do fluxo de calor é feito alterando a pausa da reversão dos gases. O sistema compreende um circuito secundário de controle da temperatura do regenerador atuando na pausa da reversão e um circuito principal de controle antecipatório. Esse circuito principal utiliza um modelo matemático de previsão baseado na temperatura final do coque para a determinação da temperatura objetivada do controle de temperatura do regenerador. A figura 10 ilustra os dois controles. A região delimitada pelo retângulo pontilhado inferior é o controle secundário, onde tem um circuito de controle PI da temperatura do regenerador atuando na pausa da reversão, cujo modelo de controle é baseado na seguinte 
equação:

$$
P R_{n}=P R_{n-1}+K \cdot\left(\Delta T_{\text {reg }, n}-\Delta T_{\text {reg }, n-1}\right)+\left(\frac{K}{T_{i}}\right) \cdot T_{\text {reg }}
$$

onde PR é o tempo de pausa na reversão, K é a constante proporcional (ganho), $\mathrm{T}_{\text {reg }}$ é a temperatura do regenerador, $\mathrm{T}_{\mathrm{i}}$ é a constante integral e $\mathrm{n}$ é a ordem da variável lida.

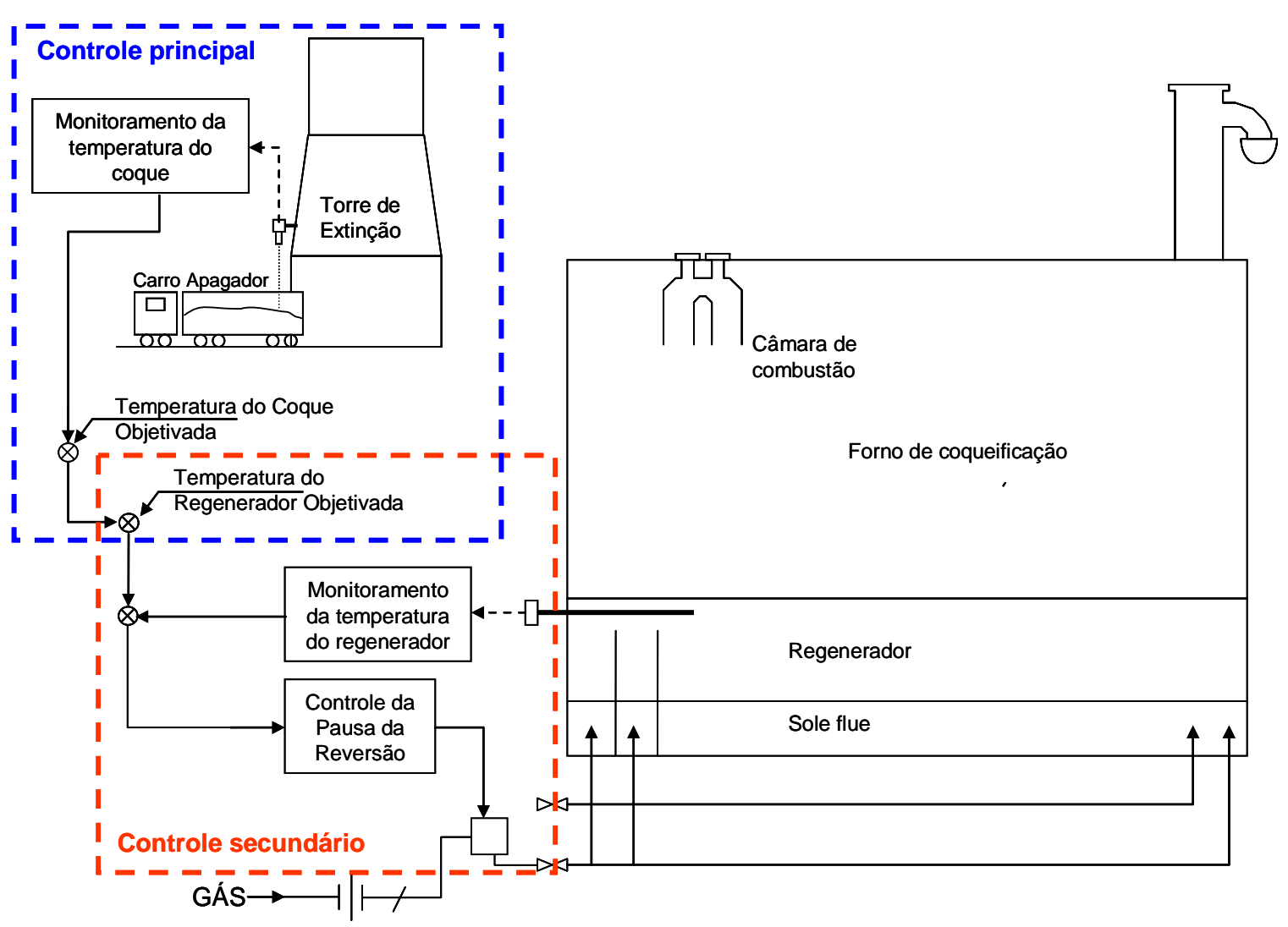

Figura 10 - Sistema CETCO de controle do Aquecimento da Corus.

A região delimitada pelo retângulo pontilhado superior é o controle principal que faz correções da temperatura objetivada do regenerador de acordo com modelo matemático dinâmico baseado nas seguintes equações matemáticas:

$$
\begin{aligned}
& \Delta T_{c t}=c \cdot T \cdot\left(1-e^{-d}\right) \\
& \Delta T_{H}=a \cdot T \cdot\left(1-e^{-b}\right)
\end{aligned}
$$




$$
\text { T.cet, } p r=\text { Tcet }+\Delta T_{H}+\Delta T_{c t}
$$

onde $\Delta T_{c t}$ é a diferença estimada da temperatura final do coque devido à variação do tempo bruto de coqueificação $\left({ }^{\circ} \mathrm{C}\right)$, c e d são funções lineares do tempo de coqueificação e o formato da escala de desenfornamento, $T$ é a média da temperatura final do coque das séries anteriores, $\Delta T_{H}$ é a diferença estimada da temperatura final do coque devido à variação do fluxo de calor injetado na bateria, $a$ é função linear do fluxo de calor anterior e posterior a dois ciclos completos de coqueificação, T é a média da temperatura final do coque das três últimas séries $\left({ }^{\circ} \mathrm{C}\right)$, b é função do tempo de coqueificação das séries, T.cet,pr é a temperatura final do coque prevista e Tcet é a temperatura final de coque medida.

d) O sistema da Siderúrgica Bhilai da Índia (Mitra et al., 2004): A coqueria da Bhilai utiliza um modelo matemático baseado em três componentes básicos: um módulo para a necessidade de calor para as baterias; um módulo para o calor em consumo pelas baterias e um módulo dinâmico para o ritmo operacional das baterias. Esses componentes trabalham interagindo entre si para prever o fluxo térmico das baterias.

A necessidade de calor é obtida através de um balanço térmico. A equação básica desse balanço é descrita abaixo:

$$
\mathrm{Ht}=\sum_{i=1}^{i=N}\left[h_{d}\left(\text { Forno }_{i}\right)+h_{l} \cdot w g+S_{h l}\right]
$$

onde: Ht é o calor total necessário; $\quad h_{d}\left(F_{0 r n o}\right)$ é o calor necessário para o forno i; $h_{1}$.wg é a perda de calor pela fumaça por forno; $S_{h l}$ é a perda de Calor pela superfície por forno e $\mathrm{N}$ é o número total de fornos da bateria. O ritmo operacional, fator que influencia no consumo de calor, é obtido pela equação:

$$
\operatorname{Tn}=\mathrm{Tn}-1+\mathrm{CPD}
$$

onde Tn é o horário de desenfornamento do enésimo enfornamento de um forno; Tn-1 é o horário de enfornamento do (n-1) enfornamento de um forno e CPD é o tempo médio de coqueificação. A figura 11 mostra esquematicamente o sistema de 
controle da coqueria indiana. O tempo líquido real de coqueificação é determinado pela temperatura máxima do gás bruto, obtida na curva do tubo de ascensão. Existe uma correlação entre o tempo de coqueificação e o tempo que essa temperatura máxima é atingida a partir do horário de enfornamento. Mitra (2004) apresenta um índice para esse fator, $\mathrm{Cl}$, que é a razão entre o Tempo de Coqueificação e o Tempo até atingir a temperatura máxima dos gases. A correlação entre o $\mathrm{Cl}$ e a temperatura da massa de coque medida dentro do carro apagador na entrada da torre de extinção através de um pirômetro de radiação infravermelho, é representado pelas seguintes equações:

$$
\begin{aligned}
& \mathrm{Fn} 1=\mathrm{Fn}-\mathrm{KCl}[\mathrm{Cla}-\mathrm{Cld}] \\
& \mathrm{Fn} 2=\mathrm{Fn} 1-\mathrm{Kt}[\mathrm{Ta}-\mathrm{Td}]
\end{aligned}
$$

onde $\mathrm{KCl}$ e Kt são constantes, Cla e Cld são respectivamente o atual e desejado índice de coqueificação $(\mathrm{Cl})$, Ta e Td são a temperatura atual e a temperatura desejada da massa de coque, Fn, Fn1 e Fn2 são fluxos térmicos, sendo o último o fluxo previsto pelo modelo.

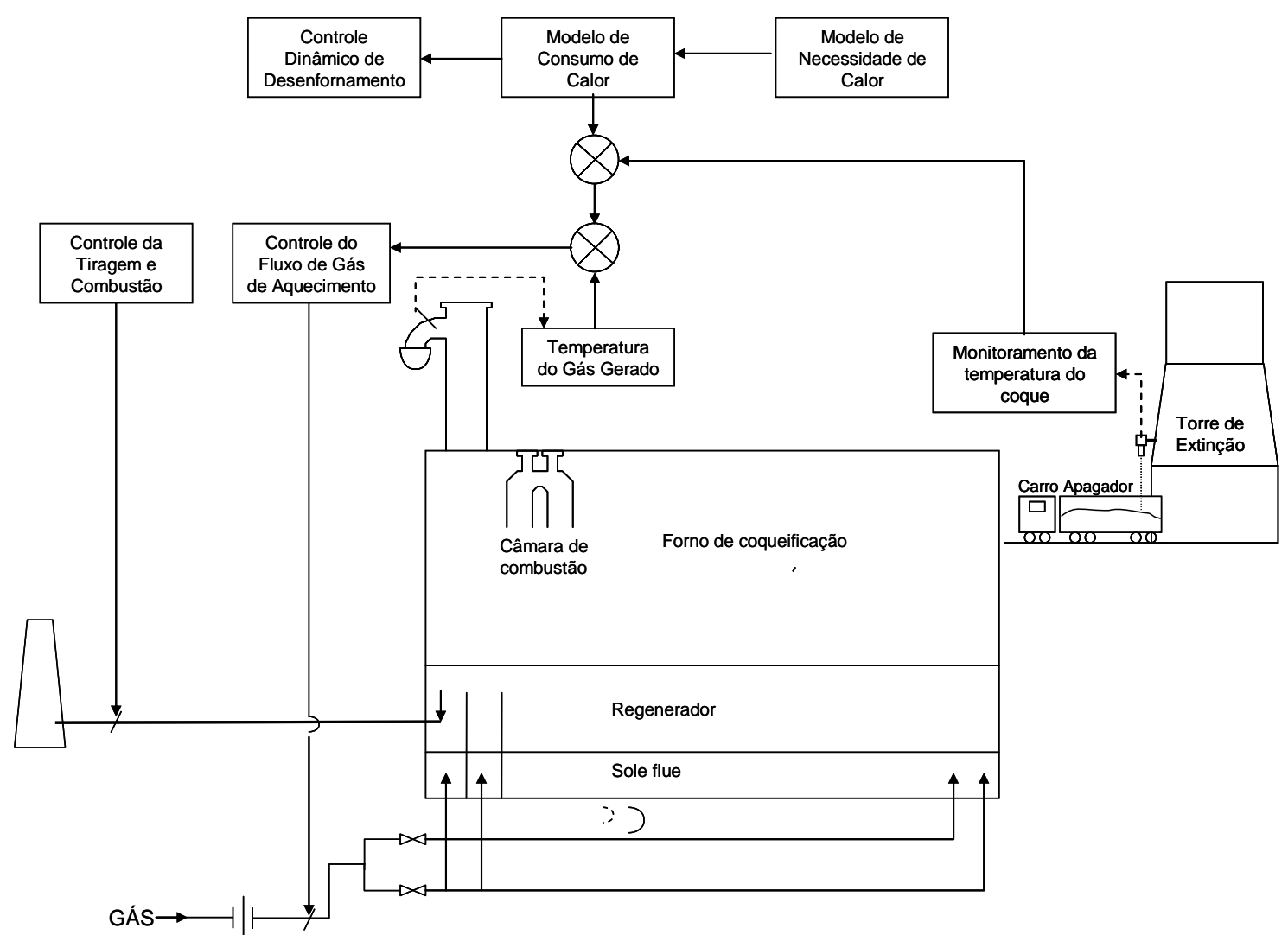

Figura 11 - Sistema de controle do processo de coqueificação das baterias da Siderúrgica Bhilai, da Índia. 
Outras usinas com controle automático utilizam basicamente uma combinação dos controles descritos acima, diferenciando-se nos sensores e nos modelos de controle utilizados, como os citados por Battle e Chen (1997). Alguns autores como Bulnova et al. (2003) e Gao et al. (2002) relatam modelos de controle considerando as paradas operacionais e fatores não controláveis.

\subsubsection{O que é mais viável implantar em automação de controle do processo de aquecimento na planta da Cosipa}

A princípio, qualquer dos sistemas apresentados acima é viável para a planta da Cosipa, mas o que será discutido nesse item é o mais adequado do ponto de vista do montante de investimentos e retorno do investimento, levando-se em conta os fatores mais significativos de cada sistema e como se comportaria na planta da Cosipa.

Os exemplos descritos acima foram escolhidos por representar diferentes formas de controle do aquecimento das baterias. Eles baseiam-se em pelo menos dois de três princípios de controle: tempo de coqueificação, temperatura do coque no desenfornamento e temperatura das paredes refratárias do forno. As diferenças estão na forma de obter esses dados e nos modelos de controle do fluxo de calor de injeção em função dos dados obtidos. Outra diferença é a forma de controle de injeção de calor. Enquanto uns controlam vazão e $\mathrm{PCl}$ dos gases combustíveis, os outros sistemas utilizam vazão e PCl constantes e variam a pausa da reversão, ou seja, variam o tempo de interrupção de fluxo de gás durante as mudanças de ponto de queima nas câmaras de combustão. A vantagem desse último é manter toda a regulagem de queima, controle da combustão, injeção de ar e a tiragem da chaminé, constantes durante as ações de gás, enquanto que o primeiro tem que, a cada variação do fluxo de gás, alterar a quantidade de ar e a tiragem da chaminé para garantir uma combustão otimizada. Por outro lado, alguns projetos de baterias têm problemas para trabalhar com pausa na reversão devido ao formato de seus regeneradores ou da composição dos gases combustíveis utilizados, que, ao ficar um tempo acima do previsto em pausa na reversão, pode-se ter mistura explosiva no interior dos regeneradores. No caso da Cosipa, a metodologia do tempo de pausa 
não é utilizada atualmente, mas será feito estudo para analisar se esse método de controle de fluxo de gás é possível de ser implantado em suas baterias.

O controle do tempo de coqueificação através do termopar no tubo de ascensão, apresentado em alguns sistemas, é simples e pode ser implantado na Cosipa. O modelo da Corus trabalha com o tempo bruto de coqueificação e não com o tempo líquido, isto é, esse modelo considera o tempo de supercoqueificação constante para as faixas de temperaturas da bateria que trabalha e também considera constantes as influências da mistura de carvão nesse tempo. Essa consideração é viável apenas quando se tem pouca variação das características da mistura de carvões e bom ritmo operacional, pois, do contrário, esses fatores irão afetar significativamente o processo.

Outra variável importante é a temperatura da parede do forno de coqueificação. Ela pode ser medida de várias formas, direta ou indiretamente. $\mathrm{O}$ modelo ACC da NSC utiliza dois sistemas de monitoração, um contínuo, indiretamente, utilizando termopares em câmaras pilotos de algumas paredes ao longo da bateria de fornos, e outro diretamente através de pirômetros no embolo da máquina desenfornadora, nesse caso, obtendo, ao longo do dia, a temperatura de todas as paredes, mas apenas a temperatura no final da coqueificação nos fornos. $O$ sistema da Sidmar utiliza a temperatura do coque na saída do desenfornamento e a leitura manual, uma vez por turno, de câmaras piloto das paredes de aquecimento. O sistema CETCO da Corus, leva em conta a temperatura da massa refratária sobre os regeneradores e a temperatura final do coque dentro do carro apagador. $O$ sistema da NSC de medição das paredes com pirômetro é mais representativo, tanto na temperatura da parede de aquecimento diretamente, quanto no volume de dados obtidos, porém é um sistema caro com sensores em regiões altamente agressivas. O pirômetro do êmbolo desenfornador opera em um ambiente de temperatura acima de $1000^{\circ} \mathrm{C}$ necessitando de um sistema de refrigeração sofisticado. Outra desvantagem desse sistema é ter a temperatura da parede apenas ao final da coqueificação. A NSC não utiliza esse sistema para controle de aquecimento ou coqueificação, utiliza-o para monitoramento das câmaras de combustão das paredes de aquecimento. O pirômetro na saída do coque do sistema da Sidmar fica num ambiente menos agressivo do que o da NSC, mas com as mesmas outras desvantagens para controle do aquecimento. O sistema da Corus com pirômetro na entrada da torre de extinção é mais simples, mas é bem menos representativo, pois 
mede a superfície do coque incandescente distribuído no vagão, dependendo de vários fatores como a distância do forno à torre de extinção e a homogeneidade da distribuição do coque no vagão. A vantagem econômica do sistema da Corus esbarra na baixa precisão das medidas da temperatura. Todas as medições têm suas vantagens e desvantagens, tanto na representatividade da temperatura da face da parede de aquecimento durante toda a coqueificação, quanto da sua durabilidade e facilidade de manutenção e também no custo de implantação e manutenção. A escolha deve ser um equilíbrio dessas vantagens e desvantagens. Dentro desses quesitos, o modelo de medição da NSC no topo das câmaras de combustão apresenta-se mais adequado às instalações da Cosipa por sua boa representatividade do processo e maior semelhança com o controle atual da operação da Cosipa.

Os modelos matemáticos apresentados estão intimamente ligados aos tipos de controles e sensores utilizados, mas sempre baseados em dados do sistema e das características de cada usina. Os modelos foram obtidos em análises estatísticas dos dados do processo. Dentro do formato do modelo de controle, cada um desenvolveu suas equações matemáticas para controle antecipatório e de retro alimentação. A proposta para a planta da Cosipa é, num primeiro momento, investir no controle de coqueificação através de termopar no tubo de ascensão para medir a temperatura do gás gerado e controle da temperatura média das baterias através de termopares no topo das câmaras de combustão como na NSC. O controle da temperatura de todas as câmaras de cada parede das baterias continuará sendo manual duas vezes por mês. Dentro dessas condições, será necessário desenvolver um modelo matemático para correlacionar os itens monitorados, tempo líquido de coqueificação e temperatura média das baterias, com a necessidade de calor de aquecimento.

Ao definir as variáveis de controle temperatura média das paredes de aquecimento das baterias e o tempo líquido de coqueificação baseado na medição da temperatura dos gases gerados, necessita-se de correlacionar essas variáveis com o fluxo de calor inserido pelos gases combustíveis e pelas características e ritmo de enfornamento da carga de mistura de carvões carregada. O estudo de transferência de calor no processo de coqueificação de um forno convencional, mencionado acima neste capítulo, mostra a influência, principalmente, da porosidade, da temperatura da parede do forno, da umidade da mistura de carvões e 
da constituição dos carvões dessa mistura na estimação do tempo líquido de coqueificação e do consumo de calor para esse processo. O escopo deste trabalho é escolher e analisar as variáveis que poderão auxiliar no controle automático do processo de coqueificação dos fornos de coque da Cosipa através de análise estatística em um projeto de experimentos em forno piloto de coque. Para análise das variáveis mencionadas acima num forno piloto, a umidade e a temperatura da parede são de simples manipulação e medição. Já os fatores porosidade e constituição dos carvões são mais difíceis de mensurar. No caso da porosidade, um método de controle utilizado industrialmente que pode ter uma correlação é a granulometria dos particulados do carvão, medida através da porcentagem de material passante numa peneira de 3,36 mm. Essa correlação não é muito boa porque a distribuição granulometria é bastante heterogênea entre os carvões envolvidos, mas ela tem a vantagem de ser utilizada industrialmente onde tem condições de ser controlada. Quanto à constituição e características dos carvões, a quantidade de dados existentes sobre condutividade térmica, porosidade interna e calor específico, além da quantidade de calor gerada ou consumida durante a coqueificação são pequenas e o número de carvões utilizados torna proibitivo o levantamento desses valores de todos os carvões utilizados. No capitulo 4 será detalhada a forma de escolha das variáveis para delineamento do projeto de experimentos.

O objetivo da automação do processo de coqueificação é a redução do consumo de calor e o aumento da produtividade. O controle do tempo líquido de coqueificação atual da Cosipa através da observação visual exige um tempo de supercoqueificação mais alto para garantir a qualidade do coque por causa da baixa confiabilidade desse método. Com uma medição mais precisa do tempo líquido de coqueificação, pode-se garantir a qualidade necessária com um tempo de supercoqueificação menor. Nesse caso pode-se ou aumentar a produtividade ou reduzir o consumo de calor ou até as duas coisas ao mesmo tempo. O presente trabalho pressupõe um tempo de supercoqueificação constante dentro dos valores que garantam a qualidade do coque para os altos fornos e trabalha com a variação do tempo líquido de coqueificação através da manipulação de variáveis do processo como mostrados nos capítulos a seguir. 


\title{
Capítulo 3 O PROJETO DE EXPERIMENTOS
}

\begin{abstract}
A análise dos parâmetros de um processo industrial requer grande conhecimento e domínio desse processo e a capacidade de fazer experimentos representativos do sistema em estudo como um todo, incluindo suas condições de contorno. A metodologia do projeto de experimentos descrita nesse capítulo vem atender a esses requisitos. Essa metodologia é ainda mais adequada quando o experimento é realizado em escala piloto, devido ao maior controle das variáveis envolvidas. Entretanto, os experimentos realizados em escala piloto perdem em representatividade para o processo industrial. Para obter uma comparação com o processo industrial, devem-se buscar parâmetros de comparação com aquele em escala piloto. Um experimento em escala industrial foi executado para, exatamente, buscar esses parâmetros de comparação.
\end{abstract}

\subsection{Os conceitos básicos do Projeto de Experimentos}

Montgomery (2005) cita que um projeto de experimentos estatístico se refere a um processo de planejamento de um experimento para que dados apropriados, que podem ser analisados por métodos estatísticos, sejam devidamente coletados e se possam obter conclusões válidas e objetivas. Os três princípios básicos do projeto de experimentos são: a aleatorização, a repetição ou replicação e a blocagem ou agrupamento. O planejamento do projeto de experimentos segue um guia bem estruturado de forma a se obter respostas robustas aos estudos em questão, comumente chamado pelos estatísticos de delineamento. Esse guia se resume em sete tópicos a seguir:

1- Reconhecimento e definição clara do problema;

2- Seleção das variáveis respostas de solução do problema;

3- Escolha dos fatores, dos níveis de cada fator e da amplitude entre os níveis;

4- Escolha de qual projeto de experimento utilizar;

5- Execução dos experimentos; 
6- Análise estatística dos dados;

7- Conclusões e recomendações.

A metodologia de projeto de experimentos apresentada nesse trabalho é um fatorial completo, que consiste na análise das variâncias das respostas dos experimentos ordenados de forma a obter todas as interações possíveis, que busca maior precisão estatística e menor custo de experimentação. É uma ferramenta auxiliar na solução de problemas na fabricação e otimização de processos com baixo custo e maior rapidez. Como ferramenta auxiliar, ele necessita ser conduzido por especialistas do processo em estudo. O bom conhecimento do processo aliado ao método permitirá um planejamento adequado da experimentação na obtenção de respostas confiáveis na análise do processo (LUNDBERG, 2003).

Uma das vantagens dessa metodologia é a análise das interações das variáveis do processo, que, muitas vezes, tem efeito mais significativo do que as variáveis individualmente, o que é difícil de observar em experimentos simples.

O projeto de experimentos para análise de significância dos fatores de uma variável resposta pode ser feito através de um fatorial completo ou de variações desse fatorial como o fatorial fracionado, métodos de confundimento, quadrado latino e outros. A vantagem do fatorial completo sobre os demais é que ele analisa todas as interações possíveis dos fatores, ou seja, das variáveis manipuladas do experimento, mas necessita de mais experimentos para um mesmo número de fatores e a mesma quantidade de níveis, que são a quantidade de valores de cada fator no experimento. Para muitos fatores, é mais adequado o fatorial fracionado ou outros que possam analisar os dados, sem quantidades proibitivas de experimentos. Geralmente, quando se tem muitos fatores a analisar, faz-se primeiro um projeto de fatorial fracionado, eliminam-se os fatores não significativos e faz-se novo projeto com menor número de fatores, este sim com um fatorial completo, podendo analisar todas as interações possíveis. Nota-se que a escolha do tipo de projeto de experimentos a ser utilizado depende muito do conhecimento do processo que se quer analisar, da profundidade da análise que se quer fazer e das viabilidades técnicas e econômicas de sua execução (MONTGOMERY, 2005).

A notação do projeto de experimento é feita tendo o número de níveis como base e a quantidade de fatores como expoente. Para um fatorial completo de 2 níveis e 3 fatores, a notação é $2^{3}$ e corresponde a 8 experimentos. Se o projeto é com repetição, então o total de experimentos fica em 16. 


\subsection{Preparação dos Equipamentos - o forno piloto}

O forno piloto, atualmente utilizado para testar os carvões recebidos pela Cosipa, é mostrado num desenho esquemático na figura 12. As dimensões do forno piloto da Cosipa são: de $465 \mathrm{~mm}$ de largura média, $1.260 \mathrm{~mm}$ de comprimento e $1025 \mathrm{~mm}$ de altura, sendo $825 \mathrm{~mm}$ de altura útil. O forno foi preparado para a realização dos experimentos, recebendo uma manutenção preventiva para evitar problemas ao longo dos trabalhos. Além dos medidores normais do forno, foi acrescentado um medidor da energia consumida pelas resistências elétricas de aquecimento do forno. O forno é controlado por um CLP, que controla a temperatura das paredes de aquecimento e monitora, além dessa temperatura, a temperatura da carga enfornada através de termopares colocados pela porta. São utilizados três termopares na carga. Um no centro do forno, outro a $112 \mathrm{~mm}$ da parede do forno e um encostado na parede do forno. O supervisório permite inserir dados objetivados nos controles de aquecimento e visualizar, através de gráficos, o comportamento das temperaturas das paredes de aquecimento e da carga enfornada, além de gerar um banco de dados. O forno também tem sensores que medem a pressão da carga e a sua contração durante a coqueificação. O forno possui equipamentos auxiliares como o êmbolo desenfornador que tem a função de desenfornar o coque depois de coqueificado, uma caçamba para receber esse coque, um silo sustentado por uma monovia que transporta a mistura de carvões ou carvão individual a ser enfornado. Há também um misturador com rosca sem-fim para homogeneizar a carga, um sistema de chuveiros para resfriar o coque desenfornado, uma balança para pesar os carvões e vários tambores, onde ficam estocados os carvões e misturas de carvões. A balança de pesagem e os medidores de temperatura e energia foram devidamente aferidos e ajustados antes de iniciar os trabalhos. 


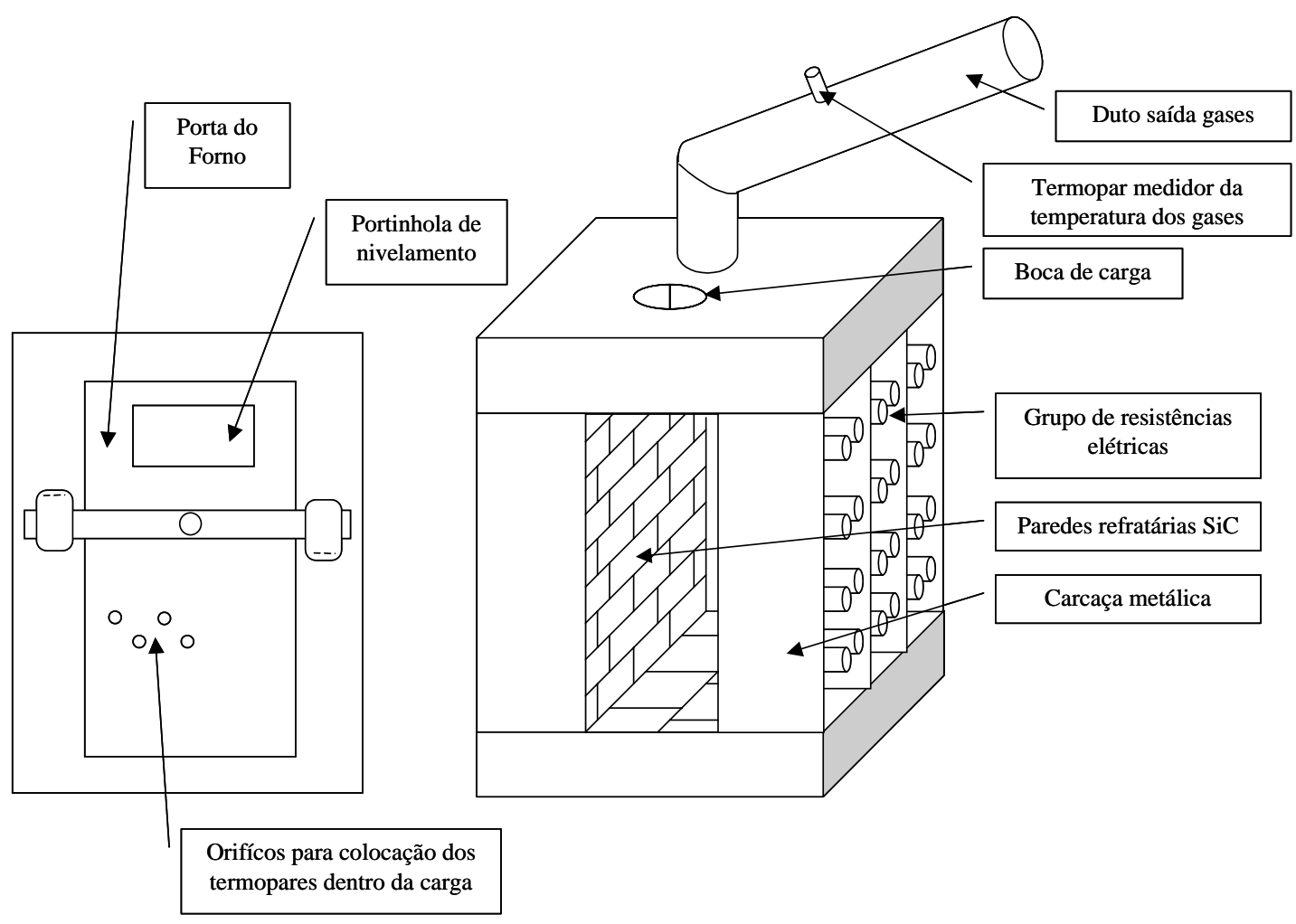

Figura 12 - Forno piloto da Cosipa utilizado nos testes.

Foram enfornados vários carvões individuais para analisar o comportamento dos sistemas de medição de temperatura e de consumo de calor. Os enfornamentos possibilitaram o acerto de parâmetros e situações como vazamentos de gás e imprecisão de alguns termopares, que foram trocados. O volume útil do forno é de 483 litros. O volume carregado pelo silo é de 488 litros. O volume interno do forno é acertado pelo nivelamento da carga, após o enfornamento, com um rodo introduzido por uma portinhola de uma das portas do forno. Caso haja excesso de material esse é retirado por essa portinhola, pesado e descontado do peso inicial. A diferença de volume entre o material no silo e o enfornado é porque houve uma compactação do material durante o enfornamento. A figura 13 ilustra o formato e o volume do silo utilizado para enfornar a mistura de carvões no forno piloto. A marca pontilhada do silo representa uma marca pintada dentro do silo onde o operador utiliza como referência do nível de material carregado no silo. Esse nível foi estipulado de forma que o volume enfornado não sobre nem falte dentro do forno.

Os termopares preparados para serem inseridos na carga enfornada são utilizados para acompanhar o processo de coqueificação dentro do forno, como mostrado pela teoria no capitulo 2. A determinação do tempo de coqueificação será obtida pelo comportamento das curvas das temperaturas medidas por esses 
termopares e também pela comparação com a temperatura das paredes de aquecimento medidas pelos termopares que fazem o controle das resistências elétricas. No forno piloto da Cosipa, os termopares de controle das resistências são instalados dentro da câmara onde ficam as resistências, mas não encostados na parede interna do forno. Devido a isso, a temperatura medida na câmara de combustão pode ser menor do que a temperatura da parede interna do forno medida pelo termopar mais próximo da parede. Esse fato ocorre devido à circulação de ar na câmara de resistências elétricas.

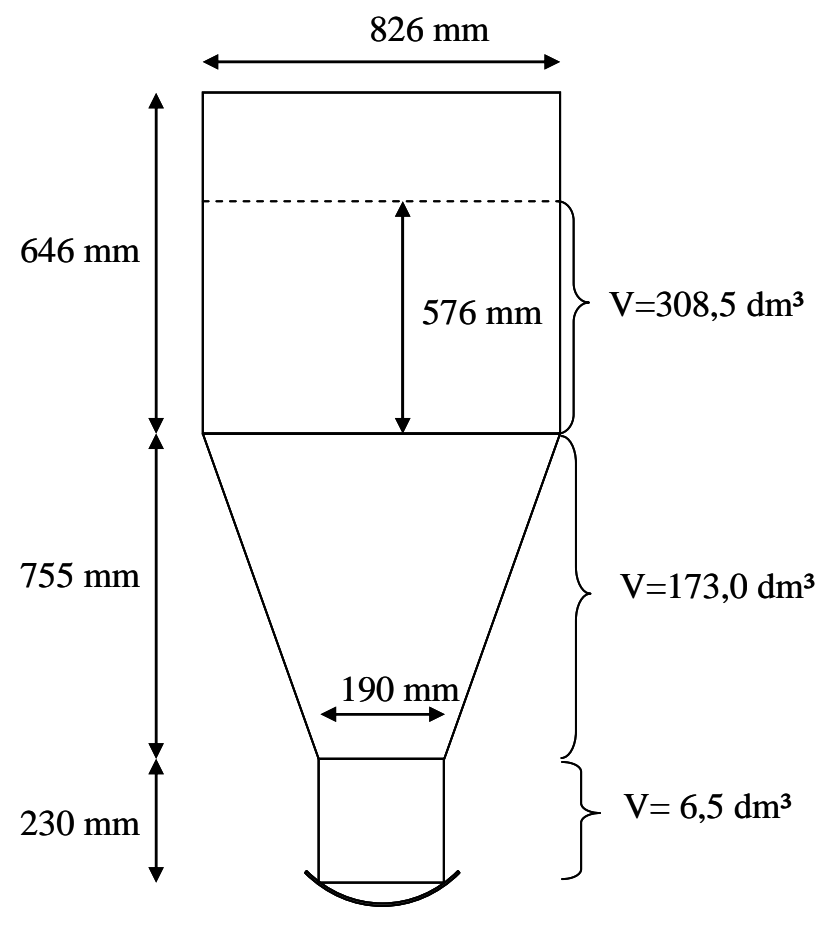

Total: $488 \mathrm{dm}^{3}$

Figura 13 - Silo de carregamento de carvão do forno piloto.

\subsection{Escolha dos Fatores e dos Níveis do Projeto de Experimentos}

A escolha dos fatores e dos níveis do projeto de experimento foi determinada pelas condições indicadas a seguir, conforme reportado por Lundberg (2003): 
a) Nível de influência no processo, informação obtida através da experiência do processo industrial;

b) Facilidade de controle no experimento com o forno piloto, ou seja, a possibilidade de se ter repetibilidade dos níveis escolhidos em cada experimento;

c) Acurácia e precisão das medições;

d) Viabilidade operacional no laboratório onde ocorrerão os experimentos;

e) O tempo total do experimento, visto que os carvões têm suas características alteradas por oxidação com o tempo. Apesar das amostras estarem devidamente embaladas, ainda assim há risco de alteração por período acima de 3 meses;

f) O grau de repetibilidade do forno piloto, torna necessário pelo menos uma repetição de cada experimento.

Levando em conta as razões descritas no item 2.3.3, o problema que se pretende resolver é a análise dos fatores que influenciam no processo de coqueificação, mais precisamente, a quantidade de calor para o processo e o tempo líquido de coqueificação. Desta forma, têm-se as duas variáveis respostas do projeto de experimento. Falta agora identificar quais os fatores mais significativos e em que níveis influenciam significativamente essas variáveis. O diagrama de causa e efeito apresentado na figura 14 dá uma dimensão dos principais fatores do processo de coqueificação que influenciam no consumo de calor e no tempo líquido de coqueificação conforme discutido no capítulo 2. Os destaques nos quadros em cinza são as variáveis escolhidas para o experimento, pois, são as variáveis mensuráveis que mais afetam o processo em questão. Os demais fatores, apesar de, potencialmente, poderem influenciar no consumo de calor, são variáveis que não atenderam a um dos critérios citados acima. Analisando cada fator do diagrama, a temperatura da parede é o fator que atende a todos os quesitos da escolha das variáveis, assim como a umidade e a granulometria. A densidade aparente, até é melhor do que a granulometria para inferir a medida da porosidade, mas há dificuldade de se obter a repetibilidade dentro do forno piloto. A forma de carregamento da mistura de carvões influencia muito nessa densidade pelo fato do carregamento ser manual e do silo apresentar constantes agarramentos de material durante a queda. Existem formas de controlar a densidade carregada, mas o forno piloto da Cosipa não tem os recursos necessários para isso. A distribuição granulométrica foi preterida em relação à granulometria menor do que 3,36 mm 
devido a não se ter esse tipo de controle de forma contínua na planta industrial. Todos os subfatores da mistura de carvões, exceto a umidade, foram descartados pela dificuldade de medição. As fissuras do coque se formam em função de vários fatores da mistura de carvões e do processo de coqueificação tendo baixa repetibilidade e também dificuldade de medição. Para não ter variação dos fatores relativos à mistura de carvões, exceto a umidade, foi programada apenas uma mesma mistura para todos os experimentos.

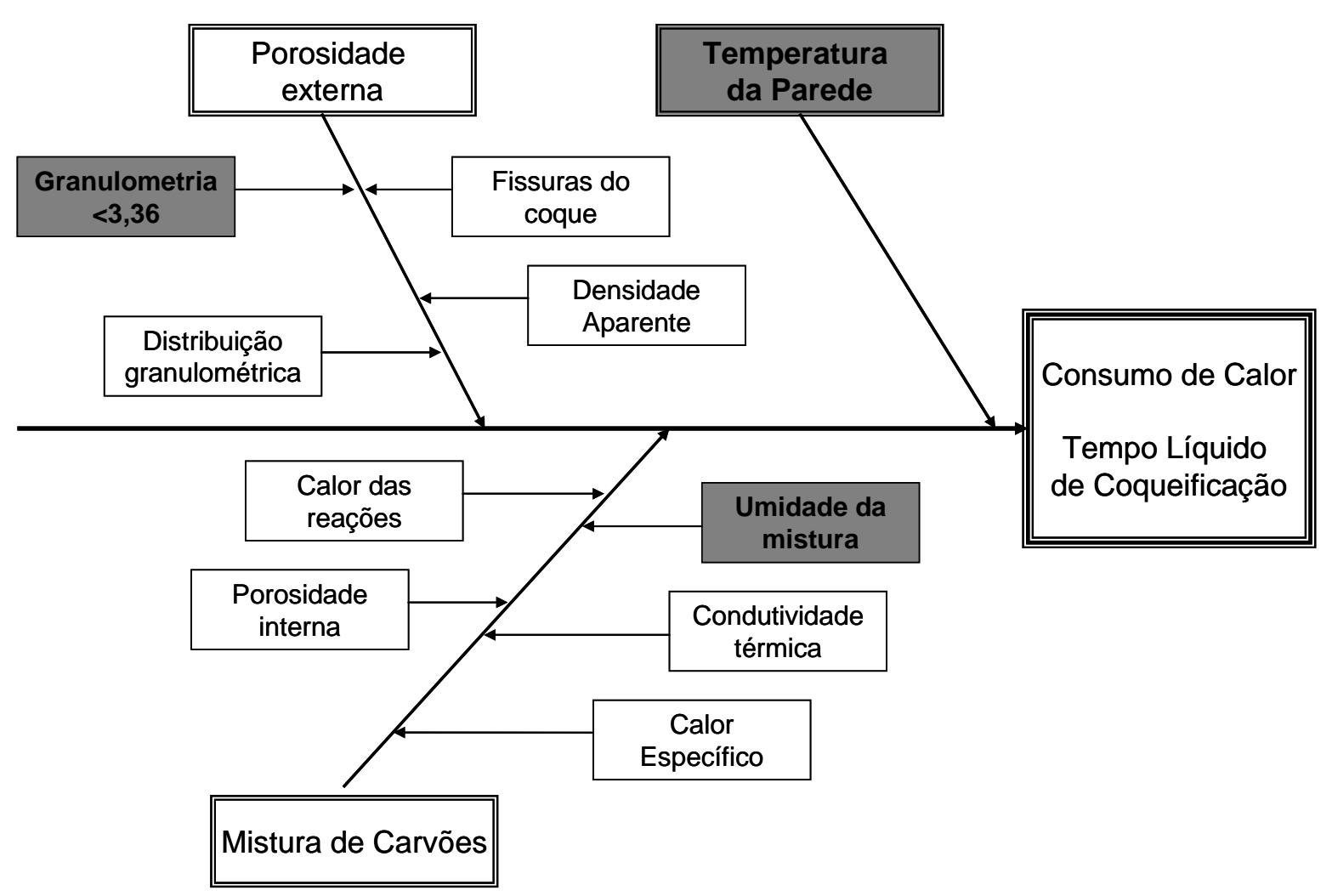

Figura 14 - Diagrama de causa e efeito do processo de coqueificação para o consumo de calor e o tempo líquido de coqueificação das baterias de fornos.

Escolhidos os fatores, umidade, temperatura e granulometria; é necessário agora definir o tipo de projeto de experimentos, os níveis e a amplitude de cada nível. Como é importante saber não somente a influência dos fatores, mas também a de suas interações, o fatorial completo se torna o projeto mais aplicável para este estudo. Partindo dessa definição, deve-se analisar, agora, a capacidade de 
execução dos experimentos. Um experimento é um enfornamento do lote selecionado no forno piloto de utilização rotineira no laboratório da unidade da Coqueria na Cosipa, ou seja, esse experimento deverá ser feito intercalando-o com a rotina da área. A duração normal de um enfornamento é de 18 a 20 horas, que se enforna na tarde de um dia e desenforna na manhã do dia seguinte. Na semana de cinco dias úteis, consegue-se fazer quatro enfornamentos. Partindo dessas premissas, há uma limitação de quantidade de experimentos, tanto na disponibilidade do forno piloto quanto no tempo de duração de todo o projeto.

Para um fatorial completo com três fatores, utilizando dois níveis e uma repetição, teremos 16 experimentos a serem executados. Considerando que se consiga utilizar a metade do tempo do forno piloto com os experimentos, teremos oito semanas para executar todos os experimentos, sem contar o tempo de coleta e preparação dos lotes, que leva pelo menos 1 mês para todo o serviço. Para esse estudo, três níveis seriam ideais, pois, poderiam apresentar correlações não lineares entre as variáveis, mas o número de experimentos subiria para 54, com a repetição, que é inviável de ser executado. Se diminuir o número de fatores para dois, o total de experimentos com três níveis iria para 18 com repetição, mas perder-se-ia a abrangência do projeto quanto aos possíveis fatores significativos. Dentro dessas razões, foi escolhido o fatorial com três fatores e dois níveis, como sendo o mais exeqüível e com maior abrangência de representatividade do processo.

A definição da amplitude do nível de cada fator foi feita de acordo com o que mais representa o processo industrial e o que é mais adequado à execução dos experimentos. No caso da granulometria, a amplitude foi definida pela coleta de material britado e não britado, resultando numa amplitude média de $6 \%$ menor de que 3,36 mm. A temperatura da parede está relacionada diretamente com o tempo de coqueificação total. O tempo máximo possível para o experimento é de 20 horas, pois, as restantes 4 horas do dia são necessárias para o desenfornamento e apagamento do coque e o processo de novo enfornamento. Assim, pela experiência da operação com o forno piloto a temperatura mínima possível da parede é de $900^{\circ} \mathrm{C}$ e considerando o processo industrial, a temperatura mais alta ficou definida em $1.000^{\circ} \mathrm{C}$. A umidade da mistura de carvões foi definida como sendo a menor, igual à menor média mensal do processo industrial nos anos de 2005 e 2006, no caso, $7 \%$ e a maior média mensal no mesmo período, 10\%. A tabela 3.1 apresenta os fatores e seus respectivos níveis definidos. 
Tabela 3.1 - Fatores e níveis do Projeto de Experimentos.

\begin{tabular}{cccc}
\hline Nível & $\begin{array}{c}\text { Fator } \\
\text { Temperatura }\end{array}$ & $\begin{array}{c}\text { Fator } \\
\text { Umidade }\end{array}$ & $\begin{array}{c}\text { Fator } \\
\text { Granulometria }\end{array}$ \\
\hline+ & Alta $\left(1.000^{\circ} \mathrm{C}\right)$ & Úmido $(10 \%)$ & Grossa (Sem Britar) \\
- & Baixa $\left(900^{\circ} \mathrm{C}\right)$ & Seco $(7 \%)$ & Fina (Britada) \\
\hline
\end{tabular}

A tabela 3.2 faz a composição dos experimentos variando a granulometria, depois a umidade e por último, a temperatura de forma que todas as combinações dos três fatores estejam presentes. Assim fica estabelecida a ordem dos experimentos que será executada duas vezes cada totalizando 16 experimentos. Essa ordem, chamada de ordem original, durante a execução dos experimentos foi mudada para uma ordem aleatória gerada pelo software Statistica, como será relatado a frente no capítulo 4. A aleatorização é importante para evitar seqüências viciosas que poderão interferir nos resultados.

Tabela 3.2 - Delineamento do Projeto de Experimentos

\begin{tabular}{cccc}
\hline Ordem & Granulometria & Umidade & Temperatura \\
\hline 1 & Fina & Seco & Baixa \\
2 & Grossa & Seco & Baixa \\
3 & Fina & Úmido & Baixa \\
4 & Grossa & Úmido & Baixa \\
5 & Fina & Seco & Alta \\
6 & Grossa & Seco & Alta \\
7 & Fina & Úmido & Alta \\
8 & Grossa & Úmido & Alta \\
\hline
\end{tabular}

\subsection{Descrição do software estatístico utilizado}

O software utilizado para os cálculos e análises do projeto de experimentos desse trabalho é o Statistica da StatSoft versão 5.1-97. O software auxilia no 
desenvolvimento de, praticamente, todas as etapas do projeto de experimentos, no que diz respeito a planejamento, cálculos, gráficos e estatísticas auxiliares. A figura 15 apresenta uma janela do software Statistica para fatorial com 2 níveis. Essa janela leva a uma tabela onde são montadas todas as interações entre os diversos fatores e também determina uma ordem aleatória para a execução dos experimentos. O software monta a tabela ANOVA ou análise de variância, o quadro de médias e desvios dos experimentos repetidos, gráficos ilustrativos dos resultados apresentados e também gráficos de análise dos resíduos como a reta da normalidade apresentada no capítulo 4.

Design of an Experiment with Two-Level Factors

DESIGN SUMMARY (standard design): $2^{* t}(3-0)$ design of resolution R $=$ FULL*

Number of factors (independent variables): 3

Number of runs (cases, experiments): 8

Number of blocks: 2

Fractional replications: 1

\begin{tabular}{|c|c|c|c|c|c|}
\hline \multicolumn{5}{|c|}{ Display/Edit/Save Design } & \multirow{3}{*}{ 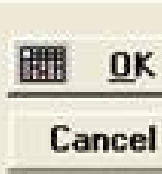 } \\
\hline 湱 & \multicolumn{2}{|c|}{ Display/print/save design } & \multicolumn{2}{|c|}{ if Factor names, yalues, etc. } & \\
\hline \multirow{4}{*}{\multicolumn{2}{|c|}{$\begin{array}{l}\text { Denote factors } \\
\text { C by Numbers } \\
\text { Cy Letters } \\
\text { by Names }\end{array}$}} & \multirow{4}{*}{\multicolumn{2}{|c|}{$\begin{array}{l}\text { Order of runs } \\
\text { \% Standard order } \\
\text { Random } \sim \text { by blocks } \\
\text { Seed: } 12512\end{array}$}} & \multirow{4}{*}{$\begin{array}{l}\text { Show [in Scrollsheet] } \\
(\text { Numbers }[+1,-1] \\
C \text { Mini/maxima } \\
\subset \text { Text values }\end{array}$} & \\
\hline & & & & & \\
\hline & & & & & \\
\hline & & & & & \\
\hline \multicolumn{5}{|c|}{ Add to the design } & \\
\hline \multirow{2}{*}{\multicolumn{3}{|c|}{$\begin{array}{l}\text { 10 genuine replicates } \\
\Gamma \text { Foldover (enhance resolution) }\end{array}$}} & \multirow{2}{*}{\multicolumn{2}{|c|}{$\begin{array}{l}\sqrt{0}-1 \text { center points (per block] } \\
0 \text { blank columns (dep. vars) }\end{array}$}} & \\
\hline & & & & & \\
\hline 䀳 & \multicolumn{2}{|c|}{ Aliasing of effects } & \multicolumn{2}{|c|}{ Generators of fractional design } & \\
\hline 瞳 & \multicolumn{2}{|c|}{ Alias matrix } & \multicolumn{2}{|c|}{ Generators of blocking variable } & \\
\hline
\end{tabular}

Figura 15 - Janela de opções de fatorial com 2 níveis do Software Statistica.

Após rodar todos os experimentos, coletar os resultados e inserir todos os dados na planilha do Statistica, este oferece várias opções de análise como mostra a figura 16. Os resultados podem ser apresentados de várias maneiras e formatos das análises tanto dos fatores e suas interações, quanto dos resíduos. Alguns gráficos e tabelas oriundos desse software serão apresentados no capítulo 4. 
DESIGN SURMARY (standard design): $2^{* \star}(3-0)$, Resolution R=FULL

Number of factors (independent variables): 3

Number of runs (standard experiment): 8

Total number of runs in experiment: 16

Number of blocks: 1

Fractional replications: Full factorial

Number of replications: 1

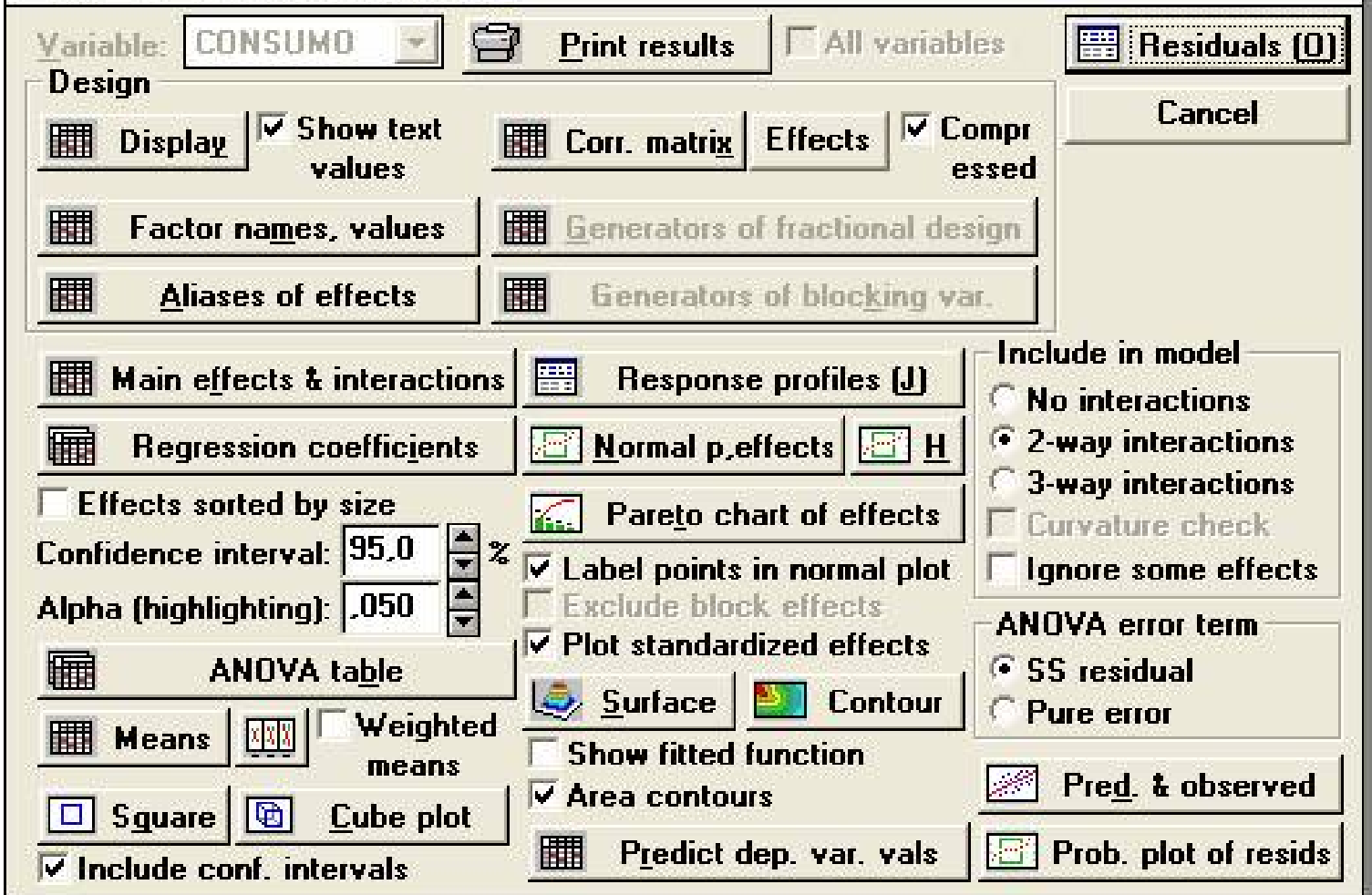

Figura 16 - Janela de opções do software Statistica para análise dos resultados do fatorial em dois níveis.

\subsection{Experimentos em fornos industriais}

Um experimento com o forno industrial é interessante para buscar a maior correspondência com o forno piloto, principalmente, com os parâmetros utilizados, com a finalidade de se estudar a possibilidade de fazer um projeto de experimentos a nível industrial. No forno piloto, a medida do consumo de calor é feita através do consumo de energia elétrica das suas resistências. No caso do forno industrial esse 
consumo é medido através da vazão de gás de aquecimento injetada nos fornos, mas não para um forno apenas e sim para todas as paredes de aquecimento da bateria de fornos. Para apenas um forno poderá ser utilizado um valor aproximado através de uma estimativa de consumo de cada parede de aquecimento. Quanto à medição do tempo líquido, no forno piloto é determinado no momento que a temperatura da carga no centro do forno se aproxima da temperatura da região da parede e começa a estabilizar. Para o forno industrial, há a dificuldade de inserir termopar na carga, como no forno piloto. A solução é inserir em um forno, esses termopares e buscar outro parâmetro correlato para essa medição do tempo líquido de coqueificação. A temperatura do gás gerado, quando atinge a sua temperatura máxima próximo ao final da coqueificação pode ser comparada com a temperatura obtida no centro da carga. Assim, é possível obter uma maneira mais fácil de medir o tempo líquido de coqueificação num forno industrial. O experimento executado num forno industrial descrito nesse trabalho tem exatamente esse objetivo.

\subsection{A importância da metodologia e da preparação}

A metodologia apresentada e todos os passos iniciais para a execução dos experimentos e os cuidados na preparação de cada etapa têm como objetivo buscar os melhores resultados dos experimentos e a melhor representatividade do processo das instalações industriais da Cosipa. O embasamento estatístico apresentado vem assegurar uma maior robustez dos valores obtidos nos experimentos. A preparação para o experimento no forno industrial também teve seus cuidados especiais para garantir que seus resultados possam realmente servir de referência para novos experimentos em fornos industriais, que são quase sempre difíceis de serem executados com sucesso. O capítulo 4 descreve a execução desses experimentos e apresenta os seus resultados. 


\section{Capítulo 4 EXECUÇÃO DOS EXPERIMENTOS}

As limitações dos experimentos para estudar os parâmetros do processo devem ser compensadas pela maior rigidez na sua condução e, nesse caso, o cuidado com cada etapa do projeto de experimentos é fundamental para o sucesso do trabalho. Este capítulo descreve os detalhes da execução dos experimentos com os cuidados necessários. Como sempre há os fatores inesperados, os cuidados em se ter reservas ou se buscar novos caminhos para contornar os problemas, são sempre necessários. Também essas situações são apresentadas abaixo e discutidas no capítulo 5.

\subsection{Preparação das misturas para o enfornamento}

Para facilitar a execução dos experimentos e manter uma boa representatividade do processo industrial, foi escolhida uma mistura de quatro tipos de carvões que corresponde, aproximadamente, a média da qualidade da mistura utilizada normalmente no processo industrial. Para perfazer 16 experimentos e mais algumas amostras de reserva, planejou-se coletar $7.200 \mathrm{~kg}$ de carvões. Para definir os níveis de granulometria foi coletado metade do material de cada carvão no pátio de recebimento de carvões e a outra metade após o sistema de britagem de carvões. Esse sistema brita os carvões individualmente e os envia para os silos dosadores da mistura, onde os carvões britados para o teste foram coletados. Cada carvão foi coletado na proporção indicada pela mistura determinada como é mostrado na tabela 4.1. Uma amostra de cada material foi coletada onde foram analisados os teores de cinzas e matéria volátil para se certificar de que cada carvão era exatamente aquele determinado para a mistura. 
Tabela 4.1 - Composição da mistura de carvões do experimento.

\begin{tabular}{cccccc}
\hline Material & $\begin{array}{c}\text { Participação } \\
(\%)\end{array}$ & $\begin{array}{c}\text { Cinzas } \\
(\%)\end{array}$ & $\begin{array}{c}\text { M. Volátil } \\
(\%)\end{array}$ & $\begin{array}{c}\text { Não britado } \\
(\mathrm{kg})\end{array}$ & $\begin{array}{c}\text { Britado } \\
(\mathrm{kg})\end{array}$ \\
\hline AV & 15,0 & 6,29 & 31,68 & 540 & 540 \\
MV1 & 35,0 & 8,48 & 21,84 & 1260 & 1260 \\
MV2 & 30,0 & 7,59 & 25,89 & 1080 & 1080 \\
CP & 20,0 & 0,58 & 11,82 & 720 & 720 \\
\hline
\end{tabular}

Os carvões foram acondicionados em tambores, identificados e levados para o laboratório de preparação de mistura para o forno piloto. Primeiro, foram separados 24 latões para receber a mistura, sendo que cada dupla de latões compôs uma carga de enfornamento; depois, para garantir uma boa homogeneização da mistura, ela foi montada de acordo com o seguinte procedimento:

a) Todo carvão AV foi colocado no misturador, misturado por 30 minutos e 0 material foi distribuído igualmente nos 24 tambores, de modo que cada tambor recebeu 22,5 kg de carvão $A V$;

b) $420 \mathrm{~kg}$ de carvão MV1 foram colocados no misturador por 30 minutos e depois foram distribuídos $17,5 \mathrm{~kg}$ desse material em cada um dos 24 tambores. Isto foi repetido mais duas vezes até completar os $1260 \mathrm{~kg}$ do material;

c) $540 \mathrm{~kg}$ de carvão MV2 foram colocados no misturador por 30 minutos e depois foram distribuídos $22,5 \mathrm{~kg}$ desse material em cada um dos 24 tambores. Isto foi repetido mais uma vez para completar os $1080 \mathrm{~kg}$ do material;

d) $360 \mathrm{~kg}$ do material $\mathrm{CP}$ foram colocados no misturador por 30 minutos e depois foram distribuídos $15 \mathrm{~kg}$ desse material em cada um dos 24 latões. Isto foi repetido mais uma vez para completar $720 \mathrm{~kg}$ do material;

e) em cada etapa acima, foi coletado um incremento de 250 gramas de material em cada tambor para compor uma amostra por tambor de todo material colocado dentro desse tambor;

f) foi feito análise das cinzas, da matéria volátil e da granulometria do material amostrado.

O mesmo procedimento foi seguido para os carvões britados em outros 24 latões. Cada dupla de latões foi etiquetada e recebeu uma numeração como está 
mostrado na tabela 4.2. Nessa tabela estão os resultados das análises feitas em cada tambor. Entre o material britado e o não britado, houve uma variação de 6 a 8 $\%$ da granulometria. Esperava-se uma granulometria mais fina do material britado, mas a forma de coletar esse material provocou segregação de material mais grosso devido à dificuldade de acesso para a coleta. A matéria volátil das misturas obtidas teve uma variação de 1\%, dentro do esperado. Quanto ao teor de cinzas, este ficou praticamente igual entre os dois lotes, assegurando a homogeneidade das misturas quanto ao teor de cada tipo de carvão. A tabela 4.2 mostra também uma seleção nas oito primeiras linhas com valores de granulometria mais próximos. Os latões com materiais mais discrepantes ficaram como lotes reservas dos experimentos. Essa seleção foi necessária para aumentar a homogeneidade dos níveis do fator granulometria.

Tabela 4.2 - Seleção e Identificação do material a ser utilizado nos experimentos.

\begin{tabular}{|c|c|c|c|c|c|c|c|}
\hline \multicolumn{4}{|c|}{ MATERIAL SEM BRITAR } & \multicolumn{4}{|c|}{ MATERIAL BRITADO } \\
\hline Lotes & Cinza & MV & $\begin{array}{c}\text { Granulometria } \\
\%<3,36 \mathrm{~mm}\end{array}$ & Lotes & Cinza & MV & $\begin{array}{c}\text { Granulometria } \\
\%<3,36 \mathrm{~mm}\end{array}$ \\
\hline $2 S$ & 6,4 & 21,9 & 68,6 & 1B & 6,5 & 20,8 & 74,2 \\
\hline $3 S$ & 6,6 & 21,9 & 70,4 & 2B & 6,7 & 21,0 & 75,3 \\
\hline $7 S$ & 6,4 & 22,1 & 66,6 & 4B & 7,2 & 21,0 & 75,4 \\
\hline $8 S$ & 6,5 & 22,2 & 69,4 & $5 B$ & 6,6 & 21,6 & 74,2 \\
\hline 9S & 6,5 & 22,1 & 66,8 & 7B & 6,8 & 21,4 & 75,3 \\
\hline $10 S$ & 6,6 & 22,0 & 68,9 & 10B & 6,3 & 21,0 & 74,1 \\
\hline $11 S$ & 6,7 & 22,2 & 70,7 & 11B & 6,4 & 21,1 & 74,4 \\
\hline $12 S$ & 6,8 & 22,5 & 68,9 & $12 B$ & 6,3 & 21,2 & 74,9 \\
\hline Média & 6,5 & 22,1 & 68,8 & Média & 6,6 & 21,1 & 74,7 \\
\hline $1 S$ & 6,23 & 22,04 & 72,8 & $3 B$ & 6,61 & 21,22 & 77,3 \\
\hline $4 S$ & 6,93 & 21,83 & 61,5 & $6 \mathrm{~B}$ & 6,49 & 21,26 & 75,9 \\
\hline $5 S$ & 6,74 & 21,91 & 74,2 & $8 B$ & 6,37 & 21,08 & 77,5 \\
\hline $6 S$ & 6,45 & 21,52 & 62,4 & $9 B$ & 6,35 & 21,24 & 76,5 \\
\hline
\end{tabular}

O acerto da umidade foi feito no momento de preparação de cada lote de mistura para o enfornamento. Na seqüência descrita a frente, cada lote foi colocado no misturador e dele foi retirada uma amostra para analisar a umidade. Com o resultado dessa análise, fez-se a correção para o valor objetivado, $7 \%$ ou $10 \%$ conforme o plano do experimento, colocando água ou deixando o material rodando 
dentro do misturador para provocar a sua secagem. Esse procedimento de acerto foi feito imediatamente antes do enfornamento, para evitar alteração da umidade com o tempo. A cada etapa de enfornamento também foi retirado uma amostra para análise de cinzas, matéria volátil, umidade e granulometria.

\subsection{Enfornamento e desenfornamento das misturas de carvão}

Através do software Statistica, o projeto de experimento foi delineado numa ordem conforme a tabela 3.2 e depois o software Statistica atribuiu uma ordem aleatória para a execução dos experimentos. A seqüência aleatória dos enfornamentos é mostrada na tabela 4.3. Durante a execução dos experimentos houve dois deles que tiveram problemas e foram repetidos com os lotes reservas.

Tabela 4.3 - Seqüência de enfornamento com os dados de densidade.

\begin{tabular}{ccccc}
\hline $\begin{array}{c}\text { Data do } \\
\text { Enfornamento }\end{array}$ & Granulometria & Umidade & Temperatura & $\begin{array}{c}\text { Densidade } \\
\text { Aparente }\left(\mathrm{kg} / \mathrm{m}^{3}\right)\end{array}$ \\
\hline 20/06 16:10 & Grosso & Úmido & Baixa & 594,2 \\
21/06 16:00 & Fino & Úmido & Alta & 569,4 \\
22/06 15:20 & Grosso & Seco & Alta & 590,1 \\
26/06 14:10 & Grosso & Seco & Alta & 603,5 \\
27/06 16:00 & Grosso & Úmido & Baixa & 619,0 \\
28/06 16:00 & Fino & Úmido & Baixa & 596,3 \\
03/07 16:00 & Fino & Úmido & Baixa & 584,9 \\
11/07 16:00 & Fino & Úmido & Alta & 592,1 \\
12/07 15:00 & Grosso & Úmido & Alta & 600,4 \\
13/07 16:00 & Grosso & Seco & Baixa & 612,8 \\
18/07 16:00 & Fino & Seco & Alta & 607,7 \\
19/07 16:00 & Grosso & Úmido & Alta & 596,3 \\
20/07 16:00 & Grosso & Seco & Baixa & 590,1 \\
24/07 14:00 & Fino & Seco & Baixa & 594,2 \\
25/07 16:00 & Fino & Seco & Baixa & 610,8 \\
26/07 16:00 & Fino & Seco & Alta & 607,7 \\
\hline
\end{tabular}

Em cada experimento, o lote de mistura de carvões foi colocado dentro do misturador, acertado sua umidade como descrito no item 4.1 e colocado no silo de enfornamento. Esse silo foi pesado e encaminhado através de uma monovia com 
guincho até o topo do forno piloto. O forno foi previamente aquecido à temperatura objetivada em cada experimento, de forma que a temperatura da parede estivesse no valor correto no momento do enfornamento. Sobre a boca de carregamento do forno aberta, abriu-se a comporta do silo e iniciou o enfornamento da mistura de carvão. Para facilitar a queda do carvão, foi utilizada uma barra introduzida por um orifício na lateral do silo. Após ser todo esvaziado, o silo foi retirado do topo do forno e a boca de carregamento foi fechada. Através de uma portinhola no alto de uma das portas do forno, nivelou-se a carga do forno com um rodo metálico numa altura estabelecida de forma que todos os enfornamentos ficassem com o mesmo volume enfornado. Com o valor do peso do material enfornado, calculou-se a densidade aparente dentro do forno. Imediatamente após o nivelamento, foram colocados os

três termopares na porta do forno, sendo um termopar próximo à parede, um no meio entre o centro do forno e a parede e o último exatamente no centro do forno. A tiragem do gás de coqueria gerado foi regulada para manter o forno sempre com pressão positiva, o que não foi possível nos momentos finais do tempo do experimento. Passadas as vinte horas determinadas para o experimento, foram retirados os termopares, abertas as duas portas do forno e desenfornado o coque com um êmbolo empurrado por um cilindro hidráulico, fazendo o coque cair dentro de uma caçamba. A caçamba foi levada para o chuveiro e o coque foi extinto com água. Após resfriado, o coque foi encaminhado para análises de qualidade.

\subsection{Execução do experimento no forno industrial}

Com o objetivo de estudar uma correlação dos experimentos em forno piloto com a planta industrial, foi feito um experimento com um enfornamento em um forno industrial da Bateria 5 da Cosipa. Na porta do forno foram feitos 6 furos em duas alturas. Uma a 1,5 metros e outra a 4 metros da soleira do forno. Em cada altura os furos ficaram alinhados de forma que um ficasse próximo de uma parede de aquecimento do forno, o segundo, próximo da outra parede de aquecimento e o terceiro no centro do forno. Após o enfornamento desse forno, foram introduzidos termopares nesses furos a uma distância, para dentro da carga de carvão enfornada, de 2,5 metros em relação ao batente da porta do forno. Nesse forno 
também foi instalado um termopar na curva do tubo de ascensão para medir a temperatura dos gases gerados e determinar o tempo em que a temperatura do gás atingiu ao seu valor máximo no terço final da coqueificação. Os dados dessas temperaturas foram coletados e plotados em gráfico como mostra a figura 17 . Um dos termopares teve problemas e não se conseguiu a medida da temperatura nesse ponto. A dificuldade de introduzir os termopares na carga de carvão foi grande e não se conseguiu saber se cada termopar ficou na posição que se desejava, ou seja, um no centro do forno e os outros dois, próximos às paredes. O gráfico da figura 17 mostra a tendência das temperaturas tanto da carga de carvão como dos gases gerados. A temperatura do gás gerado atingiu um ponto máximo de $634^{\circ} \mathrm{C}$ em 11 horas e 56 minutos após o enfornamento. As temperaturas da carga medida pelos termopares inferiores começaram a ter a mesma taxa de elevação 3 horas e 32 minutos após a temperatura dos gases gerados terem atingido o seu máximo. A temperatura medida pelos termopares superiores também começaram a ter a mesma taxa de elevação de temperatura próximo do tempo dos termopares inferiores.

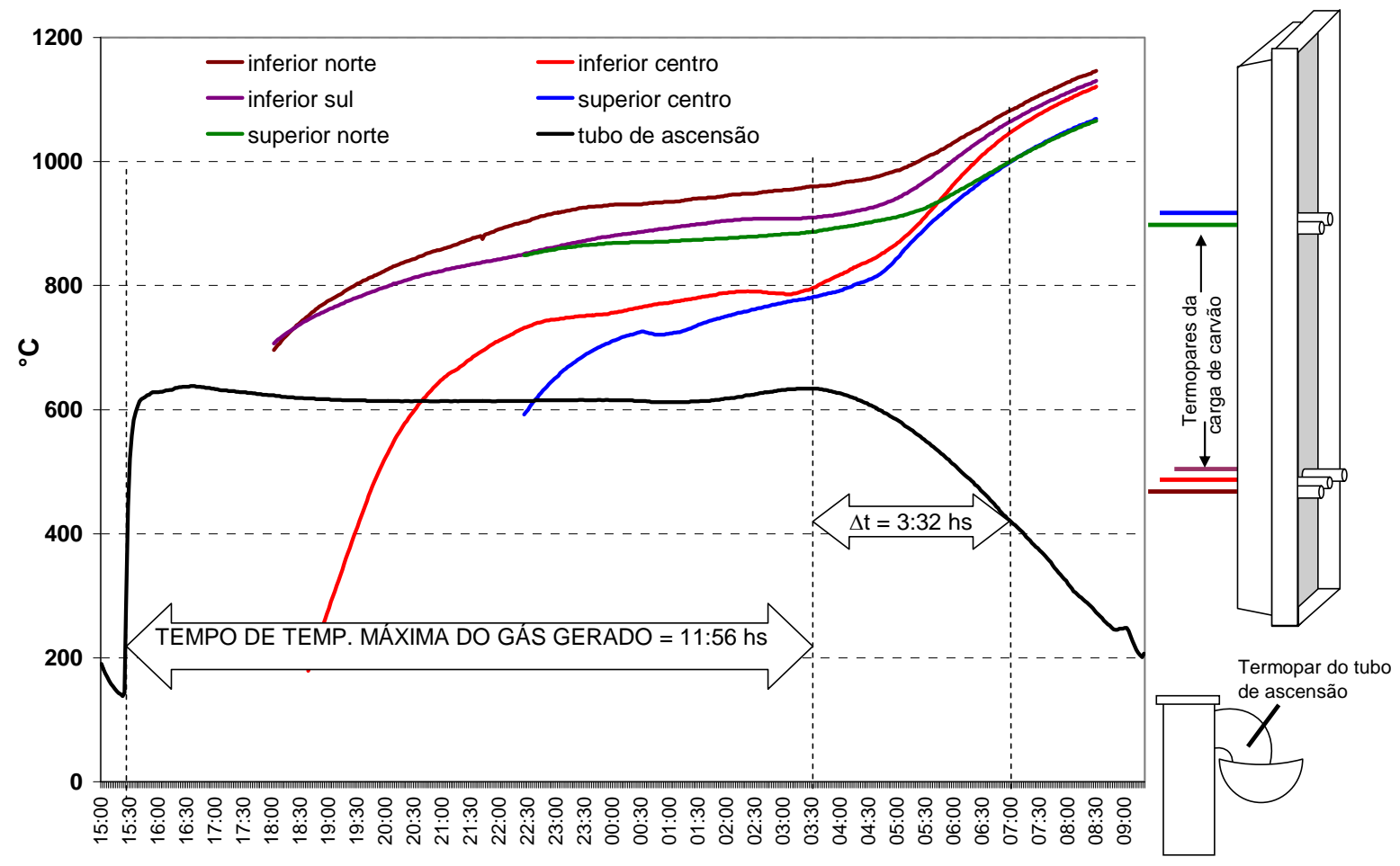

Figura 17 - Temperaturas medidas da carga de carvão e do gás gerado do forno 72 da Bateria 5 da Cosipa. 


\subsection{Análise do desempenho da execução dos experimentos}

No que se refere aos procedimentos e a execução dos experimentos, estes ficaram dentro das expectativas. Cada enfornamento foi feito dentro do programado e as medidas de temperatura, peso e consumo de energia foram tomadas dentro do esperado e armazenadas no banco de dados do supervisório do forno teste. Os valores contínuos foram armazenados de segundo em segundo e curvas em função do tempo foram plotadas para análise e determinação dos resultados pretendidos como o tempo líquido de coqueificação e o consumo de energia. Tanto os resultados de cada enfornamento no forno piloto quanto aqueles obtidos no forno industrial se apresentaram conforme mostrado na literatura ( $\mathrm{CHOI}$ et al,1997; LIA, 1987; MERRICK, 1993). 


\section{Capítulo 5 DISCUSSÃO DOS RESULTADOS}

\subsection{Apresentação dos resultados dos enfornamentos}

Após o final dos experimentos, os dados foram organizados para serem analisados estatisticamente através do Software Statistica. Os dados do experimento em forno industrial, por ter sido apenas um, teve apenas uma análise gráfica dos valores de temperatura obtidos.

A tabela 5.1 apresenta os resultados do consumo de calor e do tempo líquido de coqueificação obtidos em cada experimento. Nessa tabela, diferente da tabela 4.3, os dados estão dispostos na ordem original do delineamento do projeto de experimentos, conforme a tabela 3.2 , acrescentadas as repetições. A temperatura objetivada pelos controladores do CLP era de $900^{\circ} \mathrm{C}$ e $1000^{\circ} \mathrm{C}$, de acordo com cada experimento, mas, em função de algumas deficiências das resistências, os valores ficaram um pouco abaixo desse valor objetivado. Os valores obtidos de consumo de energia são os valores medidos das resistências elétricas de aquecimento do forno piloto. Nesse valor estão incluídas todas as perdas de calor do sistema que integra o forno.

O tempo líquido de coqueificação foi definido como o tempo entre o enfornamento da mistura de carvões no forno piloto e o momento em que a temperatura do termopar do centro do forno atinge uma diferença de mais ou menos $5^{\circ} \mathrm{C}$ em relação à temperatura média dos termopares das zonas de aquecimento centrais das paredes do forno. Esse tempo líquido definido é um pouco maior do que o tempo do momento final do envelope plástico dentro do forno, mas é o mais preciso de ser medido, o que é muito importante para comparação dos diversos experimentos. 
Tabela 5.1 - Dados dos fatores e resultados dos experimentos.

\begin{tabular}{cccccc}
\hline $\begin{array}{c}\text { Ordem } \\
\text { Original }\end{array}$ & Granulometria & Umidade & Temperatura & $\begin{array}{c}\text { Tempo } \\
\text { Líquido }\end{array}$ & $\begin{array}{c}\text { Consumo de } \\
\text { Calor (kWh) }\end{array}$ \\
\hline 1 & Fino & Seco & Baixa & $17: 16$ & 183,02 \\
2 & Grosso & Seco & Baixa & $17: 15$ & 193,42 \\
3 & Fino & Úmido & Baixa & $17: 27$ & 222,49 \\
4 & Grosso & Úmido & Baixa & $17: 08$ & 214,49 \\
5 & Fino & Seco & Alta & $14: 46$ & 181,70 \\
6 & Grosso & Seco & Alta & $14: 21$ & 182,68 \\
7 & Fino & Úmido & Alta & $14: 39$ & 192,97 \\
8 & Grosso & Úmido & Alta & $14: 21$ & 184,96 \\
9 & Fino & Seco & Baixa & $16: 55$ & 170,81 \\
10 & Grosso & Seco & Baixa & $17: 45$ & 203,55 \\
11 & Fino & Úmido & Baixa & $17: 49$ & 217,30 \\
12 & Grosso & Úmido & Baixa & $17: 53$ & 216,69 \\
13 & Fino & Seco & Alta & $14: 14$ & 171,18 \\
14 & Grosso & Seco & Alta & $14: 28$ & 178,33 \\
15 & Fino & Úmido & Alta & $14: 17$ & 186,02 \\
16 & Grosso & Úmido & Alta & $14: 12$ & 181,21 \\
\hline
\end{tabular}

O gráfico da figura 18 apresenta as medições de temperatura média das paredes do forno medida por termopares dentro de cada zona de aquecimento onde ficam as resistências elétricas, identificado na legenda como Resistências. Apresenta também as medições de temperatura dos três termopares colocados dentro da carga, sendo um próximo à parede, identificado como Parede na legenda; um a $112 \mathrm{~mm}$ da parede em direção ao centro do forno, identificado como Meio e o termopar do centro do forno, identificado como Centro. Além das temperaturas, o gráfico apresenta também a energia consumida pelas resistências das zonas de aquecimento em kWh, identificado na legenda como Consumo, cujos valores são apresentados no eixo do lado direito do gráfico. 
Experimento 6 Temperatura $900^{\circ} \mathrm{C}$, Umidade 10\%, Mistura Britada

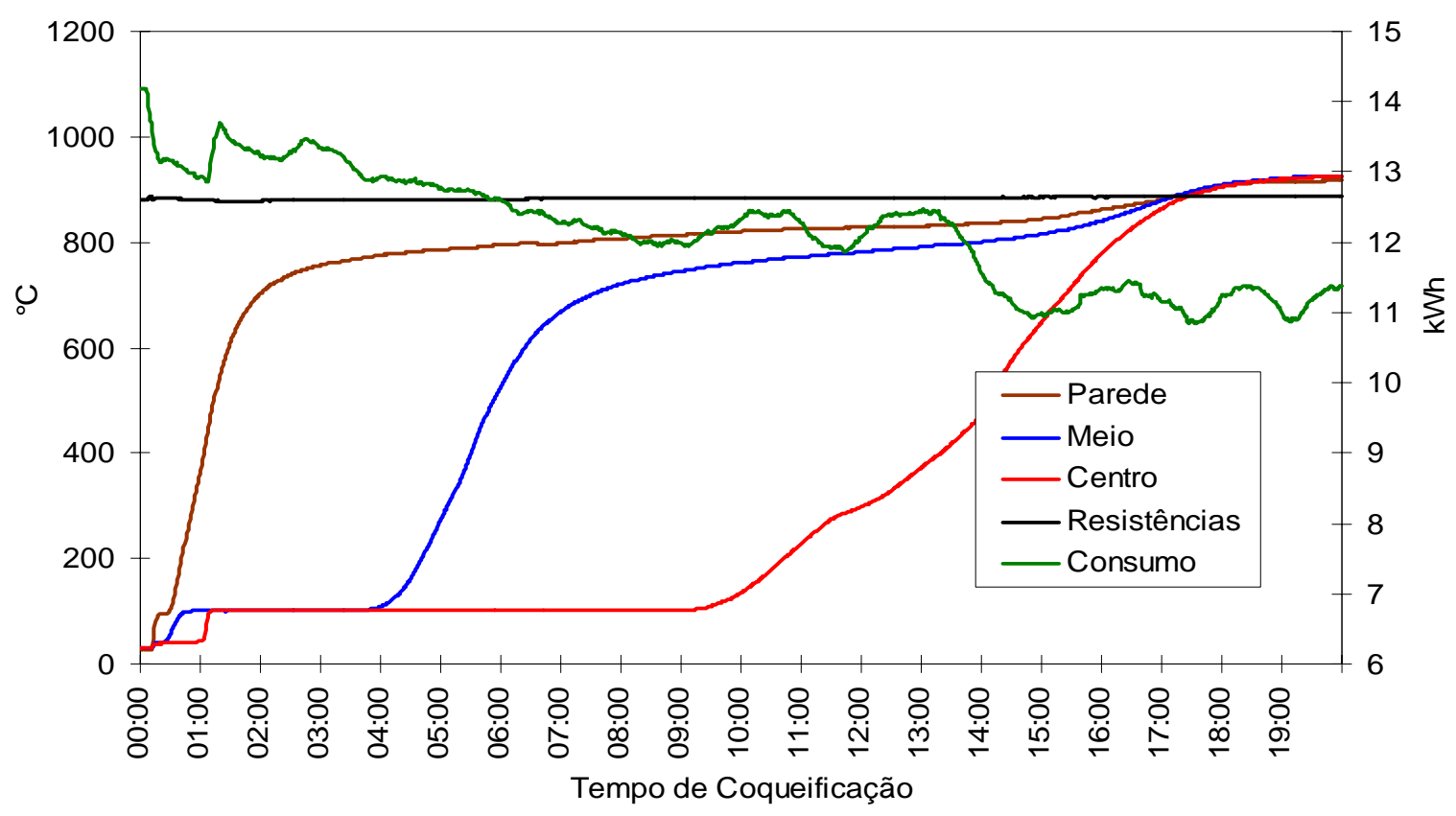

Figura 18 - Consumo de energia e temperaturas medidas para determinação do tempo líquido de coqueificação do $6^{\circ}$ experimento.

\subsection{As análises feitas através do software Statistica}

Os dados dos fatores e os resultados de consumo e tempo líquido de coqueificação da tabela 5.1 foram inseridos no software Statistica e este fez as análises dos resultados e dos resíduos para cada variável resposta.

\subsubsection{Análise dos dados do Consumo de Calor}

A tabela 5.2 apresenta o resultado da análise de variância (ANOVA) para o Consumo de Calor. $O$ valor do fator $F$, da distribuição Fisher-Snedecor, em comparação com sua curva de distribuição mostra que os fatores temperatura e umidade são significativos para o consumo de calor. Também é mostrada a significância estatística para as interações entre umidade e granulometria e entre 
umidade e temperatura.

Tabela 5.2 - Resultados da ANOVA para o efeito Consumo de Calor.

\begin{tabular}{|c|c|c|c|c|c|}
\hline Fatores e Interações & SQ & $\begin{array}{l}\text { graus } \\
\text { liberdade }\end{array}$ & MQ & $\begin{array}{c}F \\
F_{0,05 ; 1 ; 9}=5,12\end{array}$ & $\mathrm{p}$ \\
\hline TEMPERATURA & 1654,5949 & 1 & 1654,595 & 50,1498 & 0,0001 \\
\hline UMIDADE & 1433,3728 & 1 & 1433,373 & 43,4447 & 0,0001 \\
\hline GRANULOMETRIA & 55,5936 & 1 & 55,5936 & 1,6850 & 0,2265 \\
\hline TEMPERxUMID & 494,1696 & 1 & 494,1696 & 14,9780 & 0,0038 \\
\hline TEMPERxGRANUL & 96,2058 & 1 & 96,2058 & 2,9159 & 0,1219 \\
\hline UMIDxGRANUL & 330,4483 & 1 & 330,4483 & 10,0157 & 0,0115 \\
\hline Erro & 296,9375 & 9 & 32,9931 & & \\
\hline Total SQ & 4361,3224 & 15 & & & \\
\hline
\end{tabular}

Quanto ao fator granulometria, não foi apresentado para ele, significância estatística nesse teste. Numa consulta somente nos dados do projeto de experimentos, uma causa para esse resultado é a maior variabilidade dos resultados em relação à diferença dos níveis desse fator, ou seja, não foi possível afirmar através dos dados que a diferença dos níveis de granulometria é suficientemente significativa para alterar o resultado de consumo de calor. Os gráficos da figura 19 apresentam a variabilidade da granulometria com os outros fatores. Observa-se que, para a mistura úmida em temperatura baixa e para tanto mistura úmida quanto seca, em temperatura alta, os valores dos limites de confiança para o consumo se entrelaçam. Isso mostra que a grande variabilidade do fator granulometria, nesse projeto, não permite que a análise de variância afirme com grau de certeza de 95\% que esse fator é significativo para a variável resposta consumo de calor. Nesse caso, o fator granulometria deve ser considerado relevante, mesmo porque sua interação com a umidade apresentou-se significante pela análise de variância.

O gráfico de Pareto da figura 20 ilustra os resultados da análise de variância. Esse gráfico é traçado pelo software Statistica e dá uma boa dimensão do grau de significância da influência de cada fator na variável resposta Consumo de Calor. Ele é a visualização gráfica da análise de variância, mostrando os níveis de significância dos fatores e interações. 


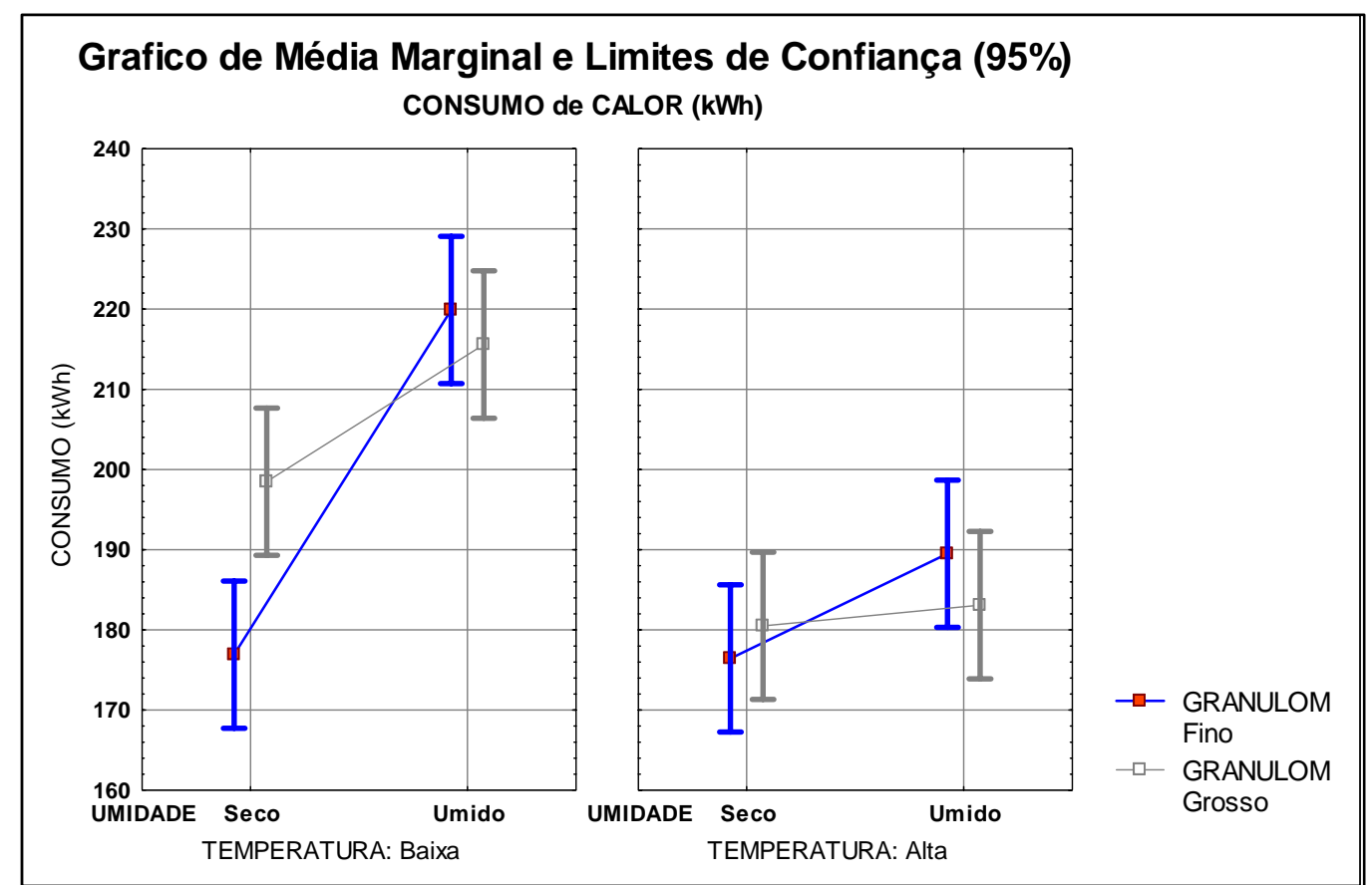

Figura 19 Média Marginal com seus limites de confiança gerados pelo software Statistica.

Uma análise importante num projeto de experimentos é saber se outros fatores não abordados estão interferindo nos resultados. Essa análise é feita através da análise dos resíduos do experimento. O comportamento desses resíduos tem uma distribuição próxima da reta normal quando não há outros fatores influenciando significativamente nos resultados do Consumo de Calor. A figura 21 apresenta um gráfico que ilustra a aproximação da normalidade dos resíduos deste experimento para a variável resposta Consumo de Calor, podendo-se afirmar que, estatisticamente, não existem fatores não considerados atuando significativamente no sistema em estudo.

Após conhecer os fatores significativos do consumo de calor, podem-se utilizar esses fatores e os resultados obtidos para gerar uma equação matemática dessas relações através da regressão múltipla. A tabela 5.3 apresenta os dados para a regressão múltipla. Nessa tabela estão os valores medidos de cada experimento. 


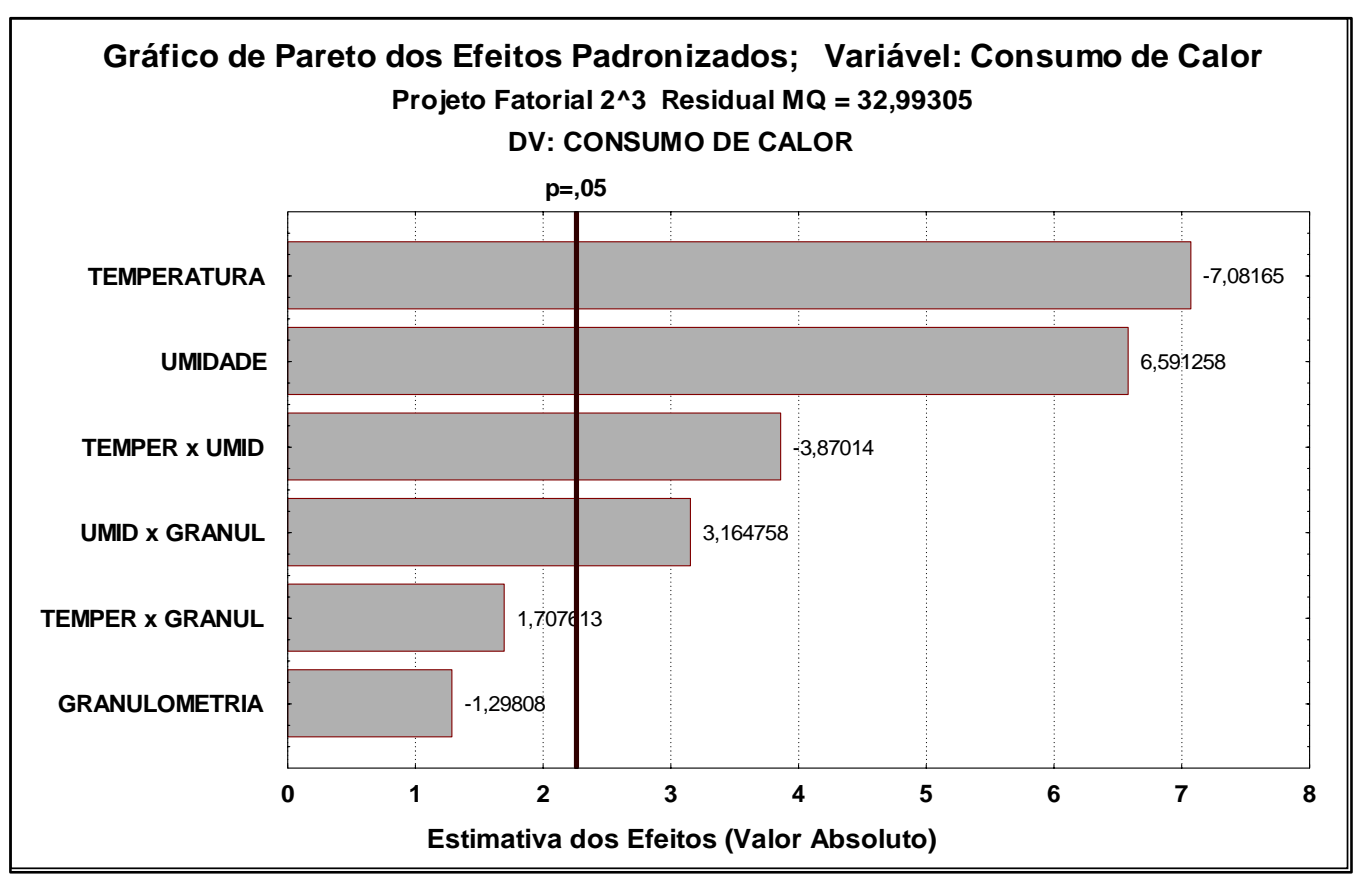

Figura 20 - Efeito dos fatores sobre a variável Consumo de Calor.

Há duas opções para a equação. A primeira é utilizar os três fatores e as interações duplas e nesse caso pode-se ter uma imprecisão na variação da granulometria. A segunda é considerar apenas os fatores temperatura e umidade e sua interação, reconhecendo a granulometria como fator não significativo e desprezando sua influência. Como não há certeza de qual equação utilizar, devemse escolher as duas para experimentações a nível industrial como ponto de partida.

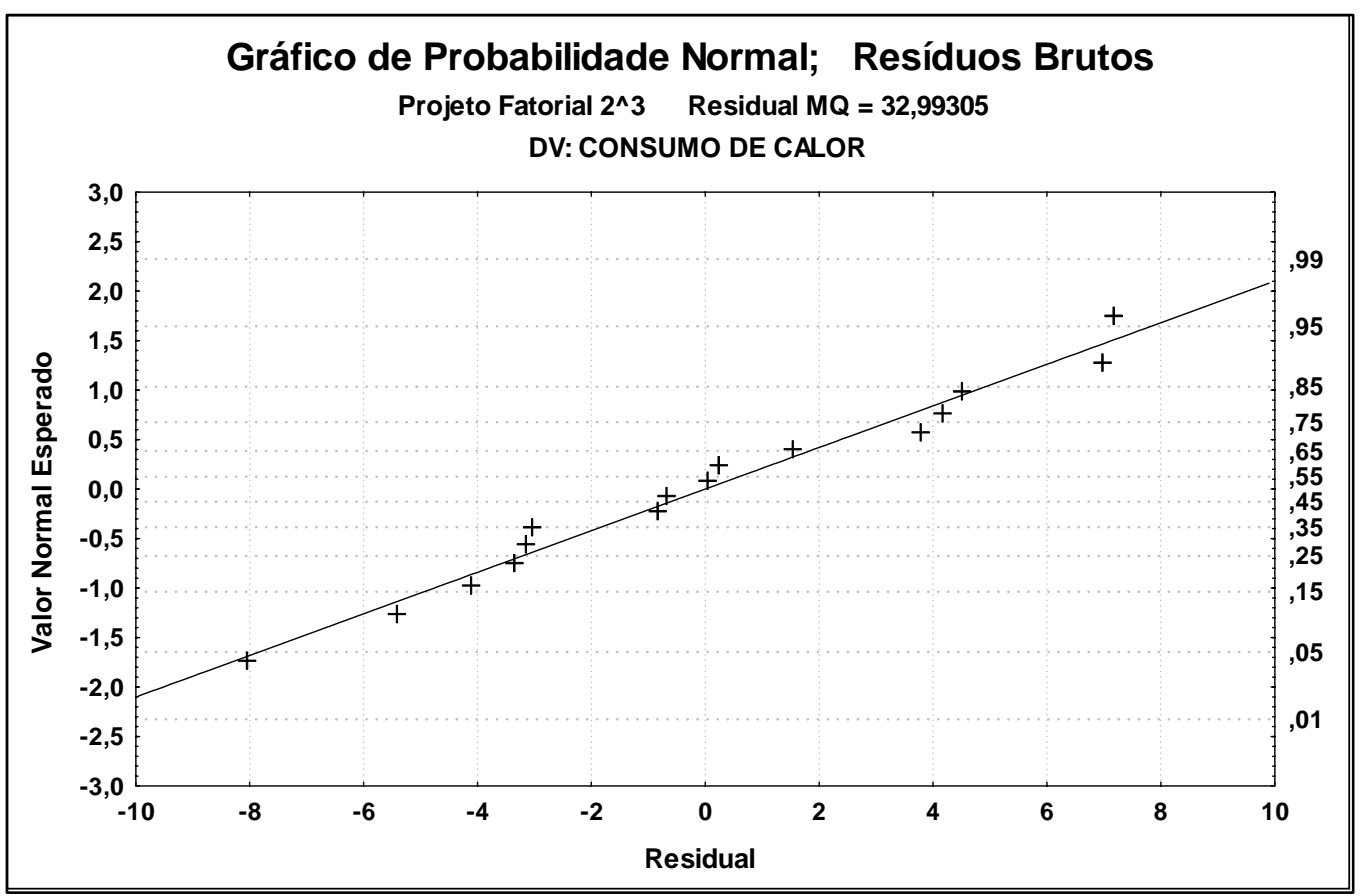

Figura 21 - Probabilidade Normal dos Resíduos para o Consumo de Calor 
A equação 5.1 foi obtida através da regressão múltipla dos três fatores e suas interações duplas e a equação 5.2 foi obtida através da regressão múltipla dos fatores Temperatura e Umidade e sua interação dupla apenas.

$$
\begin{aligned}
& \mathrm{Q}=1441,6-0,64735 . \mathrm{T}-5,3278 . U-23,193 . \mathrm{G} \\
& -0,068948 . T . U+0,014261 . T . G+1,0823 . U . G \\
& \mathrm{Q}=-307,1087+0,46438 \cdot T+82,1864 \cdot U-0,079352 \cdot T \cdot U
\end{aligned}
$$

onde Q é o consumo de calor em kWh, T é a temperatura das paredes do forno piloto em ${ }^{\circ} \mathrm{C}, \mathrm{U}$ é a umidade da mistura de carvão enfornada em \%, e G é a granulometria $<3,36 \mathrm{~mm}$ da mistura de carvão.

Tabela 5.3 - Dados reais dos experimentos para o cálculo da regressão múltipla.

\begin{tabular}{cccccc}
\hline $\begin{array}{c}\text { Ordem } \\
\text { Original }\end{array}$ & Granulometria & Umidade & Temperatura & $\begin{array}{c}\text { Tempo } \\
\text { Líquido }\end{array}$ & $\begin{array}{c}\text { Consumo de } \\
\text { Calor (kWh) }\end{array}$ \\
\hline 1 & 73,7 & 7,0 & 888 & $17: 16$ & 183,02 \\
2 & 70,7 & 7,1 & 887 & $17: 15$ & 193,42 \\
3 & 75,3 & 9,7 & 885 & $17: 27$ & 222,49 \\
4 & 68,5 & 10,2 & 883 & $17: 08$ & 214,49 \\
5 & 73,6 & 7,2 & 983 & $14: 46$ & 181,70 \\
6 & 66,6 & 7,8 & 976 & $14: 21$ & 182,68 \\
7 & 73,6 & 10,4 & 974 & $14: 39$ & 192,97 \\
8 & 68,0 & 9,8 & 975 & $14: 21$ & 184,96 \\
9 & 74,4 & 6,7 & 889 & $16: 55$ & 170,81 \\
10 & 68,6 & 7,5 & 885 & $17: 45$ & 203,55 \\
11 & 74,2 & 10,0 & 884 & $17: 49$ & 217,30 \\
12 & 66,9 & 9,9 & 884 & $17: 53$ & 216,69 \\
13 & 76,7 & 7,3 & 980 & $14: 14$ & 171,18 \\
14 & 66,8 & 7,2 & 977 & $14: 28$ & 178,33 \\
15 & 72,7 & 10,2 & 973 & $14: 17$ & 186,02 \\
16 & 67,7 & 10,1 & 977 & $14: 12$ & 181,21 \\
\hline
\end{tabular}

\subsubsection{Análise dos dados do Tempo Líquido de Coqueificação}

A tabela 5.4 apresenta os resultados da análise de variância para a variável resposta Tempo Líquido. Os valores de F da distribuição Fisher-Snedecor apontam 
para a significância estatística apenas para o fator Temperatura. Todos os demais fatores e interações, segundo esse teste, não exercem influência estatisticamente significativa na variável Tempo Líquido para o processo de coqueificação em forno piloto. O gráfico de Pareto da figura 22 dá a dimensão da significância dos fatores e interações para o Tempo Líquido, onde a temperatura se destaca dos demais fatores e interações.

Tabela 5.4 - ANOVA para a variável resposta Tempo Líquido

\begin{tabular}{lccccc}
\hline Fatores e Interações & SQ & $\begin{array}{c}\text { graus } \\
\text { liberdade }\end{array}$ & $\mathrm{MQ}$ & $\begin{array}{c}\mathrm{F} \\
\mathrm{F}_{0,05 ; 1 ; 9}=5,12\end{array}$ & $\mathrm{p}$ \\
\hline TEMPERATURA & 0,06337 & 1 & 0,06337 & 405,99253 & 0,00000 \\
UMIDADE & 0,00006 & 1 & 0,00006 & 0,40860 & 0,53861 \\
GRANULOMETRIA & 0,00000 & 1 & 0,00000 & 0,00000 & 1,00000 \\
TEMPERxUMID & 0,00022 & 1 & 0,00022 & 1,42817 & 0,26260 \\
TEMPERXGRANUL & 0,00014 & 1 & 0,00014 & 0,89289 & 0,36937 \\
UMIDXGRANUL & 0,00017 & 1 & 0,00017 & 1,11535 & 0,31845 \\
Erro & 0,00140 & 9 & 0,00016 & & \\
\hline Total SQ & 0,06538 & 15 & & & \\
\hline
\end{tabular}

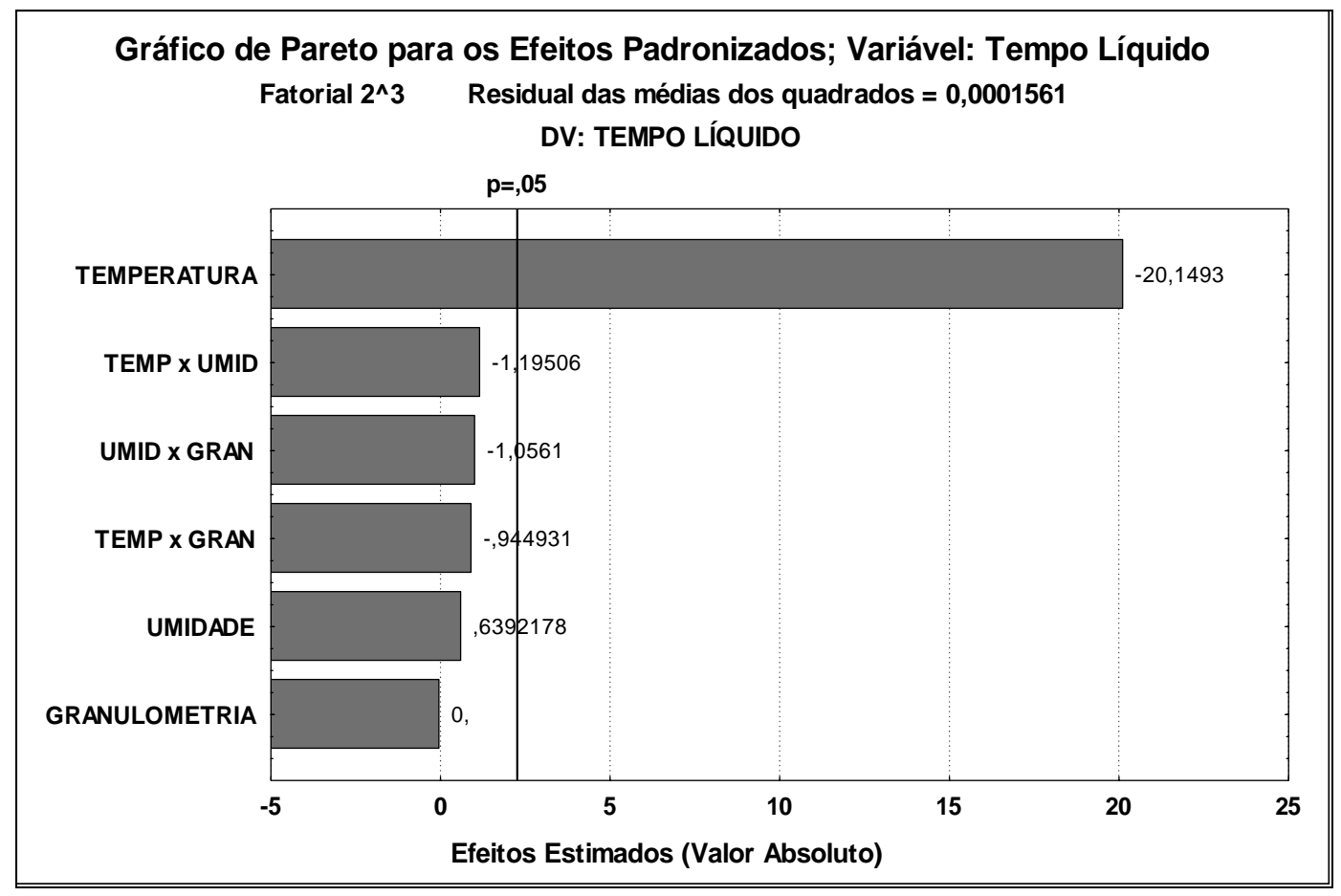

Figura 22 - Significância estatística dos fatores sobre o tempo líquido de coqueificação

A análise dos resíduos do Tempo Líquido é mostrada nos gráficos da figura 23. Aqui também, os resíduos se comportam próximos da reta normal, sinalizando boa performance dos resultados, quanto aos fatores não abordados no projeto. 


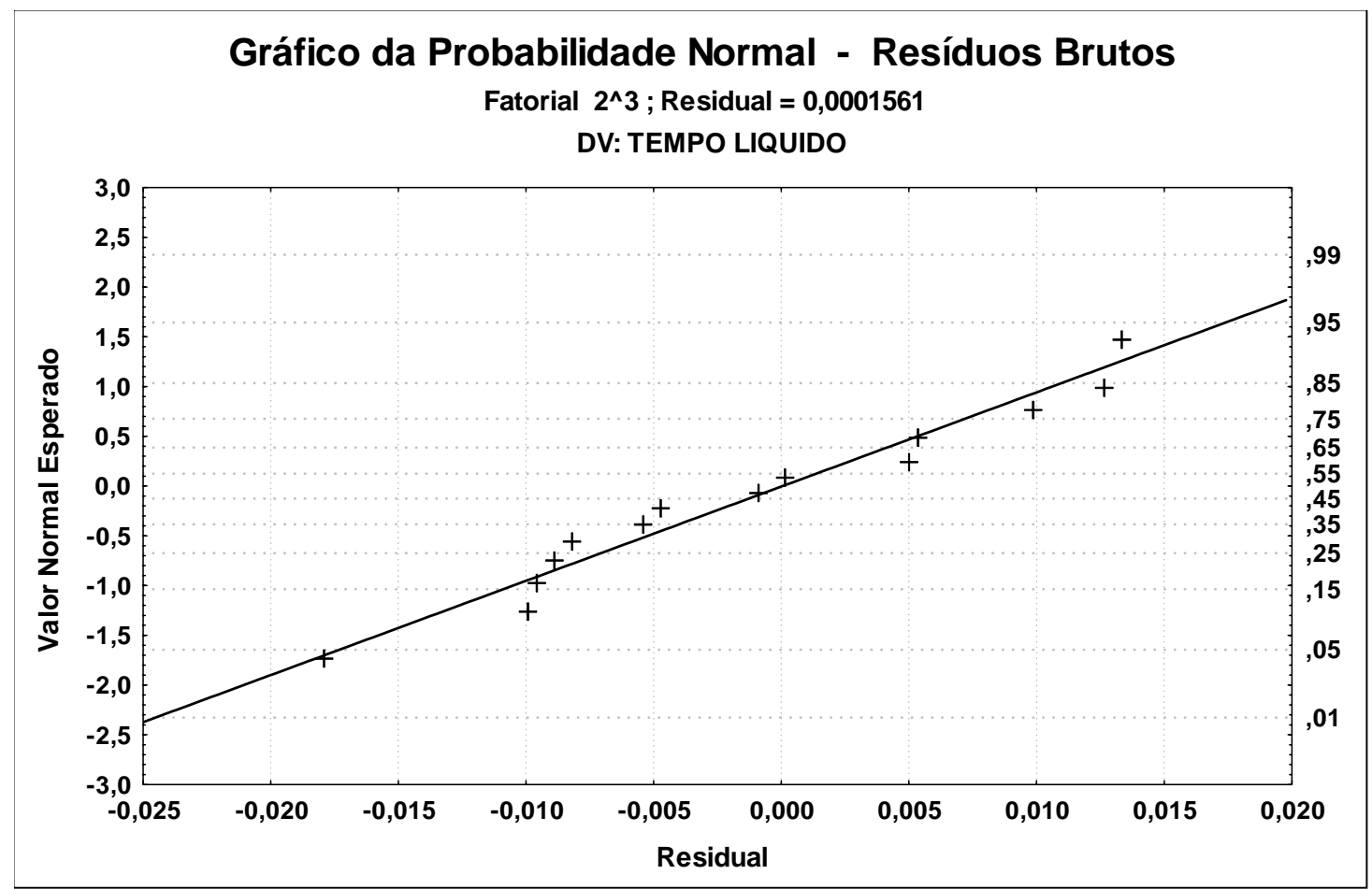

Figura 23 - Probabilidade Normal dos Resíduos para o Tempo Líquido.

A equação 5.3 foi obtida através de regressão múltipla de todos os fatores e interações e a equação 5.4 foi obtida através de regressão linear com os mesmos dados, mas considerando apenas o fator temperatura.

$$
\begin{aligned}
t_{L}= & 97,63-0,06751 \cdot T-0,90056 \cdot U-0,87089 . G \\
& -0,00112 \cdot T \cdot U+0,000655 \cdot T \cdot G+0,027794 \cdot U \cdot G \\
t_{L}= & 44,66-0,0303 \cdot T
\end{aligned}
$$

onde $\mathrm{t}_{\mathrm{L}}$ é o Tempo Líquido, $\mathrm{T}$ é a temperatura das paredes do forno piloto em ${ }^{\circ} \mathrm{C}, \mathrm{U}$ é a umidade da mistura de carvão enfornada em \% e G é a granulometria < 3,36 mm da mistura de carvão. Aqui também, serão utilizadas as duas equações como base para experimentos industriais. 


\subsection{Análise dos dados do experimento em forno industrial}

O comportamento da temperatura medida do gás gerado no tubo de ascensão foi como previsto. A elevação da temperatura atingindo um ponto máximo e depois caindo até o momento do desenfornamento é como mostrado por Sadaki; Tanaka e Naganuma (1993), onde o controle a partir do ponto máximo é descrito no capítulo 2. As temperaturas medidas nos termopares inseridos na porta do forno tinham a finalidade de repetir a mesma medição do forno piloto e definir o tempo líquido de coqueificação. Mas a incerteza da posição correta dos termopares na carga de carvão impediu uma mesma definição de tempo líquido. Nesse caso, a forma de definição do tempo líquido pode ser obtida quando as temperaturas medidas pelos três termopares inferiores e pelos dois superiores começam a subir na mesma velocidade, conforme indicado pela linha pontilhada da figura 17. A diferença entre as temperaturas dos termopares inferiores em relação aos superiores é devido ao gradiente de temperatura das paredes do forno que diminui com a altura. Essa forma de definição de tempo líquido em teste em forno industrial também é relatada por Choi et al. (1997). Esse teste mostra que é possível fazer experimentos em escala industrial para determinar o $\Delta \mathrm{t}$, ou seja, o tempo entre o momento de temperatura máxima do gás gerado e o tempo líquido de coqueificação. No teste o valor do $\Delta t$ foi de 3 horas e 32 minutos e o tempo líquido foi de 15 horas e 28 minutos, que corresponde a soma do tempo da temperatura máxima do gás gerado com o $\Delta \mathrm{t}$, como ilustra a figura 17.

\subsection{Discussão dos resultados do projeto de experimentos}

Conforme os estudos de Merrick (1983), a densidade da mistura, a temperatura da parede e a umidade da mistura têm grande influência na transferência de calor e consequentemente no consumo. O fator granulometria era esperado ter significância no consumo de calor. Uma das causas desse resultado inesperado é a fragilidade da granulometria como indicadora da densidade da 
mistura, mas esse é o único parâmetro de controle industrial para a densidade. $\mathrm{Na}$ planta industrial a granulometria média varia menos e tem maior desvio padrão do que o testado. Os gráficos da figura 24 mostram a relação da granulometria com a densidade aparente da mistura de carvões depois de enfornada. Nota-se uma grande variação da densidade para um mesmo valor de granulometria, principalmente, para umidade de $7 \%$.
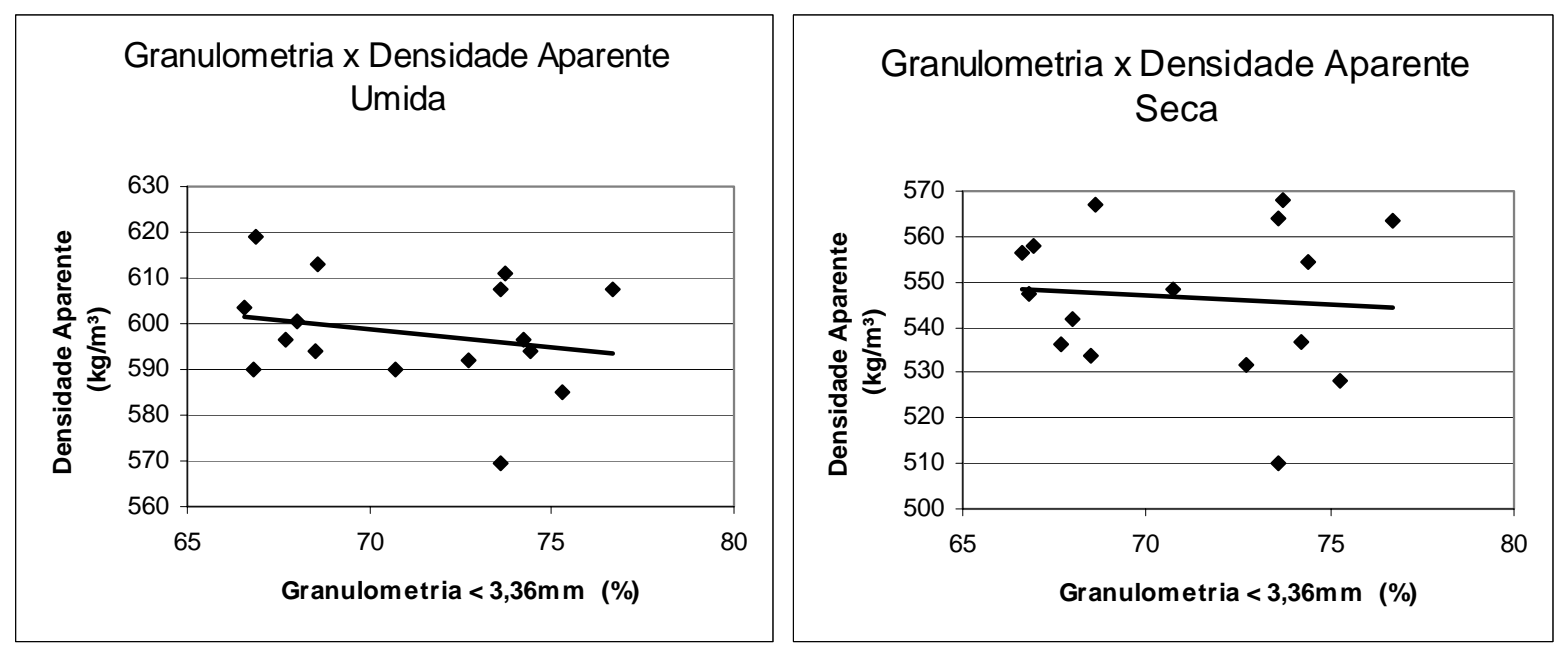

Figura 24 - Relação entre a granulometria da mistura de carvões e sua densidade depois de enfornada.

Os fatores como agarramento no silo durante o enfornamento, a abertura da comporta do silo e a própria maneira do operador manusear a barra de auxílio da queda do carvão podem ter influenciado na densidade da carga. Essa variabilidade maior da densidade e da granulometria afetou os resultados da análise estatística. Isso mostra uma fragilidade da equação obtida com o projeto de experimentos, mas os resultados dos demais fatores podem superar essa deficiência e com maior número de dados no processo industrial, esse ponto frágil poderá ser superado. $\mathrm{Na}$ planta industrial, a densidade ainda é mais imprecisa, pois, além de depender da distribuição granulométrica e da umidade, depende da forma de enfornamento pela máquina enfornadora, como a velocidade de queda, o contra-fluxo dos gases gerados e a densidade do material nos silos das máquinas. Assim, nos experimentos no forno industrial, a densidade será um desafio a ser enfrentado. Esses experimentos deverão ter maneiras ou dispositivos para minimizar os efeitos da variabilidade da densidade.

Segundo os dados obtidos por Lia (1987) em seu modelo matemático, o 
tempo líquido de coqueificação depende também da umidade da mistura de carvões e da porosidade do meio e os valores obtidos por sua equação foram $12 \%$ menores, em média, em relação aos valores medidos nos experimentos do forno piloto. $O$ valor da porosidade utilizada foi baseado em uma equação utilizada por Lia, a partir da densidade aparente. Não foi encontrado um motivo claro porque o fator umidade não afetou o tempo líquido de coqueificação. Uma hipótese é o fato de o forno piloto ter controle para manter a temperatura da parede constante, mantendo, assim, a velocidade da frente de coqueificação e consequentemente, o tempo líquido, consumindo-se mais energia. No processo industrial, o fluxo de calor é constante ao longo do processo de coqueificação e, nesse caso, uma variação da umidade pode afetar o tempo líquido de coqueificação.

Quanto ao consumo de calor a equação de Lia apresenta, em média, valores 26\% menor do que as equações 5.1 e 5.2, mas nesse caso, a diferença está nas perdas, principalmente, através do gás gerado e pela superfície do forno para o ambiente, já que o valor medido nos experimentos foi o total consumido pelas resistências elétricas do forno piloto. Loison; Foch e Boyer (1989), em seu balanço térmico de um forno de coque, apresentaram um valor de $23,1 \%$ de perdas pela superfície e pelos gases gerados.

\subsection{Discussão dos resultados do experimento no forno industrial}

O teste no forno industrial, apesar das dificuldades de execução, apresentou bons resultados, comparando com os testes no forno piloto. A intenção de utilizar a porta como ponto de introdução dos termopares na carga, foi tentar obter uma precisão maior de atingir o centro da carga. Mas a necessidade de medir mais distante da porta, pois a temperatura das paredes nas duas primeiras câmaras de combustão é bem menor do que a média, utilizaram-se poços de termopar mais longos. Ao introduzir esses poços na carga enfornada, não se conseguiu o esperado. Apesar disso, foi possível visualizar a convergência das curvas de temperatura dos termopares introduzidos na carga a partir de um determinado tempo e então ter um ponto de controle. Essa convergência foi também observada em todos os experimentos do forno piloto e também por Choi et al. (1997). Sadaki; 
Tanaka e Naganuma (1993) relatam a utilização da observação visual para definir o $\Delta \mathrm{t}$, para a determinação do tempo líquido. Esse método é muito impreciso, pois, depende da habilidade do operador e também da luminosidade ambiente, embora seja simples e pode ser repetido sem muito trabalho. Os experimentos com termopares na carga, são mais trabalhosos, mas podem dar maior precisão aos resultados, principalmente para analisar os fatores do projeto de experimentos no forno piloto. Como a precisão de acertar o centro da carga não é tão necessária para esse experimento, podem-se introduzir os termopares pelas bocas de carga como foi apresentado por Choi et al. (1997). Nesse caso, a execução do experimento em forno industrial é menos trabalhosa e um projeto de experimentos para determinação do $\Delta \mathrm{t}$ pode ser delineado.

Resolvido o problema da medição do tempo líquido de coqueificação para o forno industrial, resta equacionar a medição do consumo de calor. Teoricamente, todas as paredes de uma bateria recebem uma mesma quantidade de fluxo térmico, mas devido às obstruções dos regeneradores e dutos, há sempre diferenças entre elas. Como a medida de fluxo é feita para a bateria toda, não é possível saber, com boa precisão, qual é o fluxo de calor que cada parede recebe. No caso de um projeto de experimentos com o forno industrial, esse fluxo de calor deverá ser estimado. Outra diferença do consumo de calor entre o forno piloto e o forno industrial que precisa ser levada em conta é que, no forno piloto, o fluxo de calor não é constante, ele varia de acordo com a necessidade de manter a temperatura da parede. Já no forno industrial o fluxo térmico é constante e a temperatura da parede é que varia ao longo do tempo de coqueificação. Essa é uma diferença que deverá ser levada em conta na interpretação dos dados e na comparação com os resultados do forno piloto.

\subsection{Análise final dos resultados}

O objetivo de se conhecer os parâmetros do processo de coqueificação das baterias da Cosipa, como já descrito do capítulo 2, é de se buscar a automação do controle de aquecimento dos fornos. Com as equações obtidas através dos 
experimentos no forno piloto e com o formato do experimento no forno industrial, será possível obter os parâmetros mais próximos da realidade do processo em escala industrial. Pelos dados apresentados nos experimentos do forno piloto, é possível projetar um controle automático, que, utilizando-se a equação do consumo de calor, pode-se fazer o controle da temperatura da parede de aquecimento. E com a equação do tempo líquido de coqueificação é possível obter o valor objetivado dessa temperatura para um determinado tempo de coqueificação.

Alem dos desafios já relatados acima, a própria obtenção de uma equação representativa que venha a compor o controle do processo de aquecimento, existem os desafios de influências não abordadas neste trabalho, como a falta de ritmo operacional de desenfornamento, as variações comportamentais dos carvões utilizados, os erros de medição e até as interferências humanas no processo. Assim, a obtenção dos parâmetros do processo percorre um grande caminho no domínio da automação do processo, mas não deixa de ser o início da caminhada, que ainda terá muitas pedras para serem removidas. 


\section{Capítulo 6 CONCLUSÕES E PROPOSTAS DE PESQUISA}

\subsection{Conclusões do projeto de experimentos no forno piloto}

As análises estatísticas mostraram que os resultados obtidos através da metodologia do projeto de experimentos por fatorial completo são robustos o suficiente para ser usado como base de um modelo matemático de controle do processo de aquecimento das baterias da Cosipa. Foi possível verificar a influência dos fatores temperatura, umidade e granulometria para o consumo de calor e para o tempo líquido de coqueificação. $O$ fator granulometria, em função de sua baixa representatividade para com a densidade, não apresentou significância estatística no projeto, mas pelas análises e pela significância da interação desse fator com a umidade, mostrou-se que é um fator importante para o controle do consumo de calor.

\subsection{Conclusões do experimento em um forno industrial}

O experimento executado num forno da bateria 5 da Cosipa, para identificação do tempo líquido de coqueificação, mostrou-se adequado para aferir os dados obtidos com o forno piloto e correlaciona-lo com a temperatura máxima dos gases gerados. A determinação do valor de $\Delta t$ para o controle do tempo líquido de coqueificação em escala industrial é primordial e aferi-lo com medições mais representativas e sensíveis ao processo irá tornar o controle mais efetivo. Essa determinação do tempo líquido é necessária para a comparação com os testes realizados no forno piloto e também para o futuro controle do processo de coqueificação. 


\subsection{Futuras linhas de pesquisa}

A primeira ação após a obtenção dos resultados acima é fazer um estudo de correlação entre os resultados do forno piloto com um forno industrial através de um projeto de experimentos semelhante ao desenvolvido neste trabalho. Ao definir o $\Delta t$ para o controle do tempo líquido, será possível monitorar esse tempo instalando termopares na curva dos tubos de ascensão. E instalando termopares no topo como na NSC (SADAKI; TANAKA; NAGANUMA, 1993), para monitorar a temperatura média das paredes dos fornos das baterias, poderão ser desenvolvidas equações de correlações do controle de aquecimento e do tempo líquido de coqueificação no processo industrial.

\subsection{Considerações finais}

As variações do processo numa planta industrial será o grande desafio para a implantação do sistema automático de controle de aquecimento. Os experimentos em forno piloto têm as facilidades do controle dos parâmetros. Na planta industrial, a variabilidade dos fatores e até a dificuldade dos pontos de medição representar adequadamente os parâmetros que se quer monitorar, serão obstáculos que exigirão cuidados especiais para se obter equações que reflitam, com boa fidelidade, o processo de coqueificação de uma bateria de fornos de coque. 


\section{REFERÊNCIAS}

AMAMOTO, K. Coke strength development in the coke oven: 1 . Influence of maximum temperature and heating rate. Fuel, v. 76, n. 1, p. 17-21, 1997.

ARENDT, P. et al. Semi-technical carbonization tests: correlation to industrial-scale technology. Cokemaking International, v.10, n.1, p.41-42, 44-47, 1998.

BATTLE, E. T.; CHEN, K.L. Automatic coke oven heating control system at Burns Harbor for normal and repair operation. Fuel and Energy Abstracts, v. 38, n. 6, p. 429-429, 1997.

BULNOVA, A; KOSTÚR, K. Development of control system by Studgard neural network simulator. Acta Montanistica Slovaca, v. 8, p. 217-219, 2003.

CHISTYAKOV, A.N.; CHISTYAKOVA, T.B.; BOIKOVA, O.G. An integrated intellectual system for control of coking processes. Coke and Chemistry, v.8, p.3037, 1998.

$\mathrm{CHOI}, \mathrm{K} . \mathrm{I}$. et al. A mathematical model for the estimation of flue temperature in a coke oven. In: IRONMAKING CONFERENCE, 56., Chicago, 1997. Proceedings. Chicago: AIME Iron \& Steel Society, 1997. p.107-113.

FURLONG, M. W.; BALDWIN, R. M.; BAIN, R. L. Reactivity of coal towards hydrogenation-ranking by kinetic measurements. Fuel, v.61 p.116-120, 1982.

GAO, J. et al. Intelligent switching system methodology and its application in complex process control system. In: 2002 IEEE INTERNATIONAL CONFERENCE ON ARTIFICIAL INTELLIGENCE SYSTEMS, Divnomorskoe, Russia. 2002. Proceedings. Los Alamitos, CA.: IEEE Computer Society, 2002. p.12-17.

HOLLE, P.; VERFAILLE, J.;MUNNIX, R.; BORLEE, J. Heating and process control at the Sidmar coking plant. In: INTERNATIONAL COKEMAKING CONGRESS, 2., London, 1992. Proceedings. London: Institute of Materials, 1992. v.2, p.294-310,

JENKINS, D. R. Plastic layer permeability estimation using a model of gas pressure in a coke oven. Fuel, v. 80, n. 14 , p.2057-2065, 2001. 
JÜNTGEN, H. Review of the kinetics of pyrolysis and hydropyrolysis in relation to the chemical constitution of coal. Fuel, v. 63, n.6, p.731-737, 1984

KIDENA, K.; MURATA, S.; NOMURA, M. Studies on the chemical structural change during carbonization process. Energy \& Fuels, n.10 p. 672-678, 1996.

$\mathrm{KOCH}, \mathrm{A}$. et al. A physicochemical study of carbonization phases: part I. Tars migration and coking pressure. Fuel Processing Technology, n.45, p.135-153, 1995.

$\mathrm{KOCH}, \mathrm{A}$. et al. A physicochemical study of carbonization phases: part III. A method of predicting wall pressure by extraction with $\mathrm{N}$-methyl-2-pyrrolidinone. Fuel Processing Technology, n. 48, p. 39-50, 1996.

LARSSON, M.; WANG, C.; DAHL, J. Development of a method for analyzing energy, environmental and economic efficiency for an integrated steel plant. Applied Thernal Engineering, n. 26, p. 1353-1361, 2006.

LIA, L. R. B. Modelo matemático unidimensional do processo de coqueificação. 1987. 173p. Dissertação (Mestrado) - Departamento de Ciências dos Materiais e Metalurgia, Pontifícia Universidade Católica do Rio de Janeiro, Rio de Janeiro, 1987.

LOISON, R.; FOCH, P.; BOYER, A. Coke: quality and production. 2. ed. London: Butterworths, 1989.

LOHMANN, T.; BOCK, G.; SHLÖDER, J. P. Numerical methods for parameter estimation and optimal experiment design in chemical reaction systems. Ind. Eng. Chem. Res, v.31 p. 54-57, 1992.

LUNDBERG, S. E. Statistical design and evaluation of experiments in steel production. Steel Research International, v.74, n.6, p. 386-395, 2003.

MAHONEY, M. et al. Pilot scale simulation of cokemaking in integrated steelworks. Ironmaking and Steelmaking, v.32, n. 6, p. 468-478, 2005.

MALINA, V.P. Process control at the Sidmar Coking Plant. Coke and Chemistry, n. 9-10, p. 44-47, 1993. 
MERRICK, D. Mathematical models of the thermal decomposition of coal.

Fuel, v. 62, p. 534-561, 1983.

MINISTÉRIO DAS MINAS E ENERGIA. Balanço energético nacional: BEN 2005. Brasília, 2005.

MITRA, S. et al. Mathematical Model based Coking Control System. In: ANNUAL MEETING, 39., Seattle, 2004. Seattle: IEEE / IAS, 2004. p.183-187.

MIURA, T. Transport phenomena in coke process. In: INTERNATIONAL CONGRESS ON THE SCIENCE AND TECHNOLOGY OF IRONMAKING, $2 . /$ IRONMAKING CONFERENCE, 57., Toronto, 1998. Proceedings. Toronto: ICSTI, 1998. p.775-780, 1998.

MONTGOMERY, D. C. Design and analysis of experiments. 6.ed. Hoboken, NJ., John Wiley \& Sons, 2005.

NAKAZAKI, A. et al. Application and effects of automatic coking control. In: IRONMAKING CONFERENCE, 46., Pittsburgh, 1987. Proceedings. Pittsburgh:, AIME Iron \& Steel Society , 1987. p.299-306.

OSINSKI E. J. ; BARR P. V. ; BRIMACOMBE J. K. Mathematical model for tall coke oven battery: I - development of thermal model for heat transfer within oven charge. Ironmaking \& Steelmaking , v.20, n.5, p.350-361, 1993.

SADAKI, J.; TANAKA, K.; NAGANUMA, Y. Automatic coking control system. In: IEEE CONFERENCE ON CONTROL APPLICATIONS, 2., Vancouver, 1993. Proceedings. Vancouver: IEEE, 1993. v. 2, p.531-538.

STONE, P. M. et al. Model based control of a coke battery. In: IRONMAKING CONFERENCE, 56., Chicago, 1997. Proceedings. Chicago: AIME Iron \& Steel Society, p. 131-138.

VANDER, T.; Van BALLEGOOIE, A.L.; VOS, R.A. Automatic heating input control system batteries. In: IRONMAKING CONFERENCE, 49., Detroit, 1990. Proceedings. Detroit: AIME Iron \& Steel Society, 1990. p.127-133.

VYAS, K.J. et al. Finite element modelling of heat transfer processes and fluid dynamics in a model coke oven. In: EUROPEAN THERMAL SCIENCES, 4., Birmingham, 2004. REAPP, p. 1-7. 
YU, A.B. et al. Bulk density of coal: Effect of particle size distribution, moisture content and oil addition. In: INTERNATIONAL CONGRESS ON THE SCIENCE AND TECHNOLOGY OF IRONMAKING, 2./ IRONMAKING CONFERENCE, 57., Toronto, 1998. Proceedings. Toronto: ICSTI, 1998. p.763-772. 